CREATING CONTENT, INFLUENCING DEMOCRACY: SITUATING CORPORATE POLITICAL COMMUNICATION BETWEEN MARKETING AND ACTIVISM

$$
\text { by }
$$

Stephanie Hill

Bachelor of Arts, Princeton University, Princeton, New Jersey, USA, 2010

A thesis presented to Ryerson University and York University in partial fulfillment of the requirements of the degree of Master of Arts in Communication and Culture

Toronto, Ontario, Canada, 2017

CStephanie Hill, 2017 


\section{AUTHOR'S DECLARATION}

I hereby declare that I am the sole author of this thesis. This is a true copy of the thesis, including any required final revisions, as accepted by my examiners. I authorize Ryerson University to lend this thesis to other institutions or individuals for the purpose of scholarly research. I further authorize Ryerson University to reproduce this thesis by photocopying or by other means, in total or in part, at the request of other institutions or individuals for the purpose of scholarly research. I understand that my thesis may be made electronically available to the public. 
ABSTRACT

\title{
CREATING CONTENT, INFLUENCING DEMOCRACY: SITUATING CORPORATE POLITICAL COMMUNICATION BETWEEN MARKETING AND ACTIVISM
}

\author{
Stephanie Hill
}

\section{Master of Arts in Communication and Culture}

\section{Ryerson University}

2017

This thesis investigates the commercial backlash to a contentious piece of legislation in North Carolina and considers the implications of commercial incorporation of political content on public service communications. Commercial actors have high social standing and a privileged relationship with the social platforms used to disseminate much of commercial speech. In their pursuit of direct relationships with consumers, unmediated by publishers and free of the distrust

of advertisement that has often characterized consumer-marketer relations, brands have cultivated content marketing practices based on serving consumer interests. Access to analytical tools allows companies to evaluate the success of content, eventually creating an environment in which most companies feel comfortable taking political stands in a way they did not before the widespread adoption of social media. Closer examination of political speech by commercial entities reveals strategies of communication that undermine avenues for public exchange and short-circuit non-market means of protest. 


\section{ACKNOWLEDGEMENTS}

This thesis has greatly benefitted from the time and attention of my supervisory committee, as well as assorted friends, family, and faculty.

My thanks to my supervisor, Jeremy Shtern, whose knowledge, enthusiasm, pointed questions, constructive mockery, and thorough engagement with the subject matter enabled the research's development. I look forward to continuing the work in the PhD.

My thanks also to David Skinner and Matthew Tiessan for challenging me to fully develop my methods and results.

I would like to acknowledge the program in Communication and Culture and its program director, Paul Moore, for providing a supportive environment for this research. I would also like to thank my classmates, particularly Alex Chalk, Stacey Copeland, and Andrea Luc, and my colleagues at the writing centre for helping me to separate the wheat from the chaff as I gathered my ideas.

Special thanks to my friends Jeffrey Campbell and Sylvia Artiga, whose insightful perspectives are frequently in my thoughts. 


\section{DEDICATION}

I dedicate this thesis to my large and moderately bonkers family, who always had a lot of questions about what all these companies were up to. 


\section{TABLE OF CONTENTS}

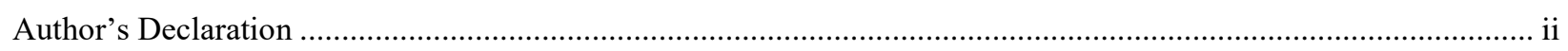

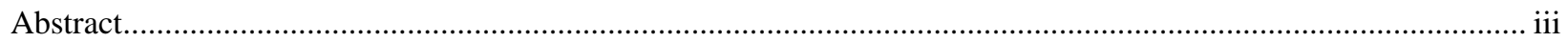

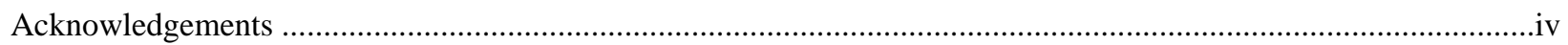

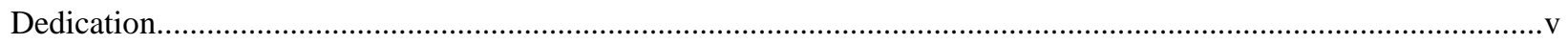

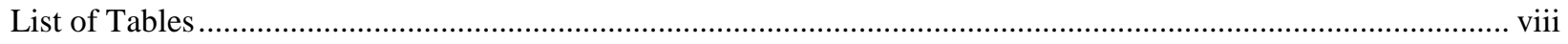

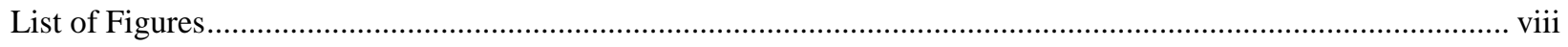

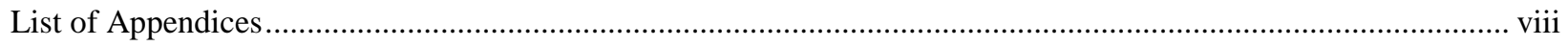

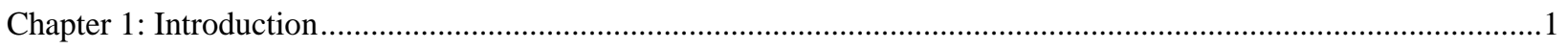

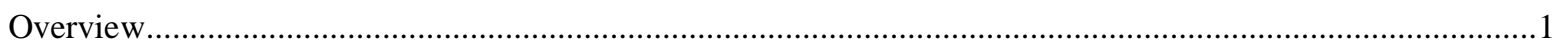

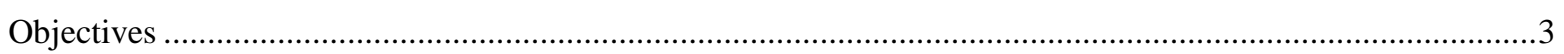

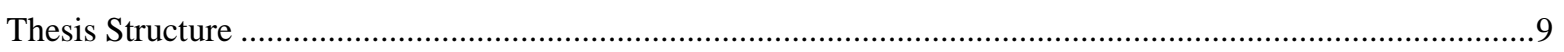

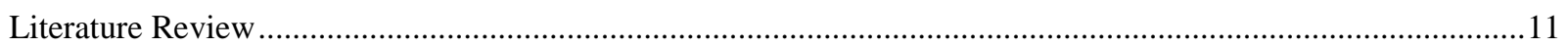

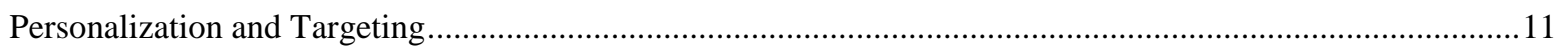

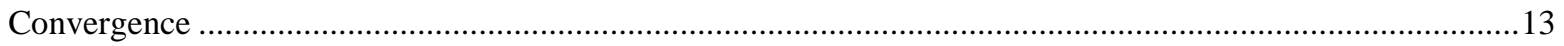

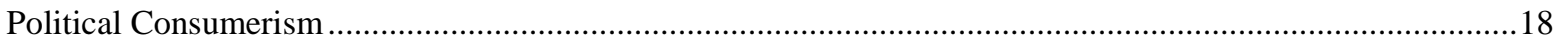

Corporate Social Responsibility, Stakeholders, and Brand Advocates ...................................................19

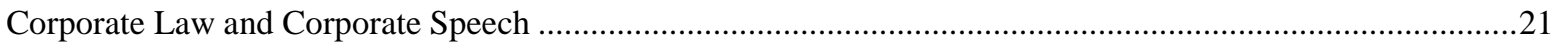

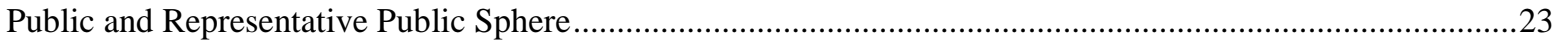

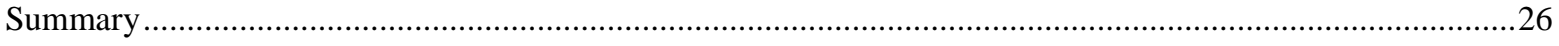

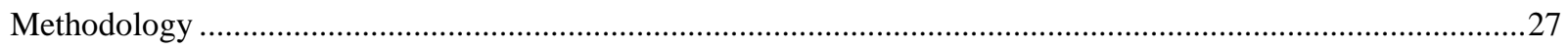

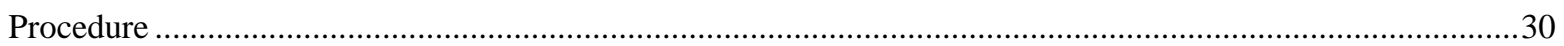

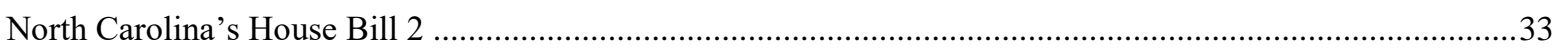

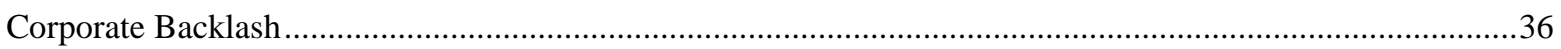

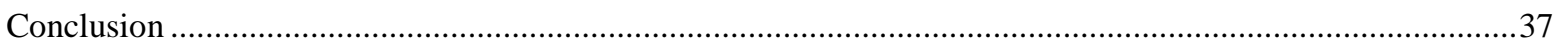

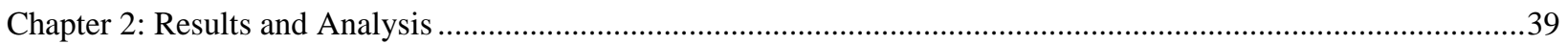

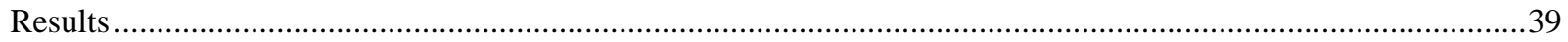

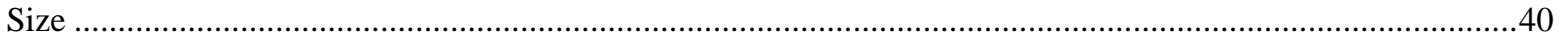

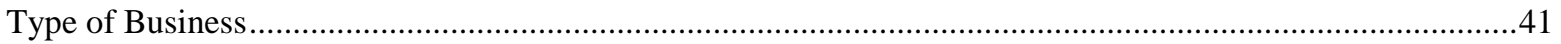

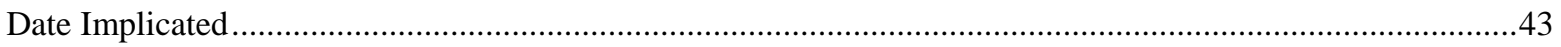

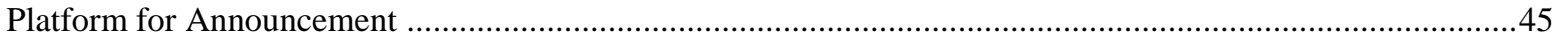




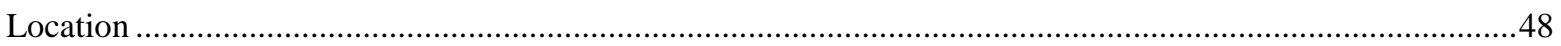

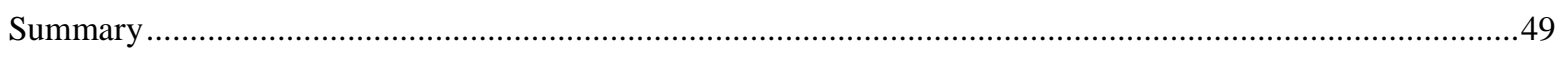

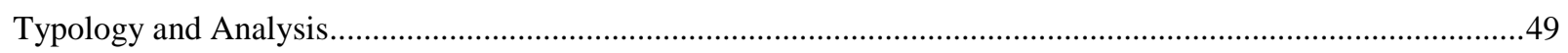

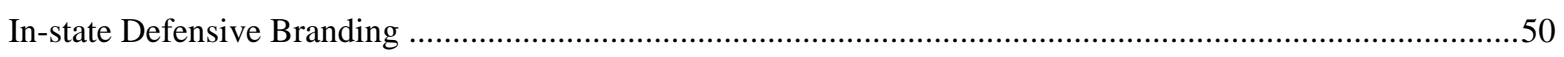

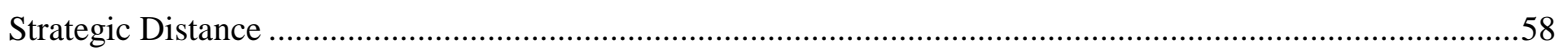

Out-of-state Content Generation (Benefit Corporations) ......................................................................60

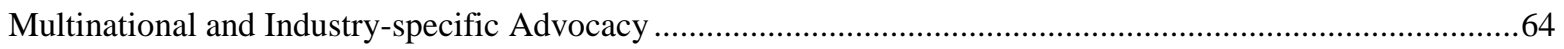

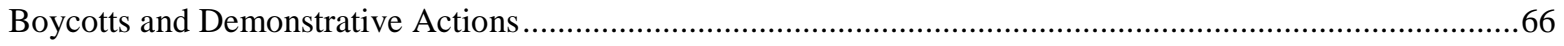

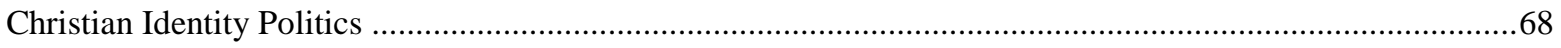

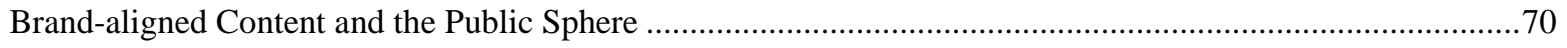

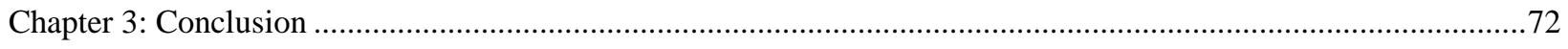

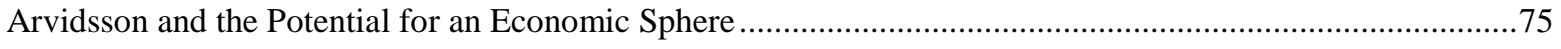

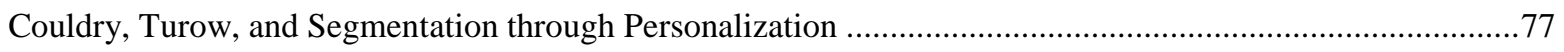

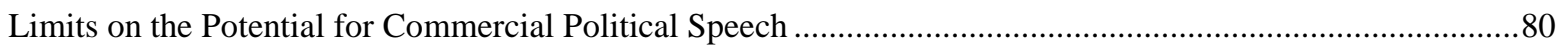

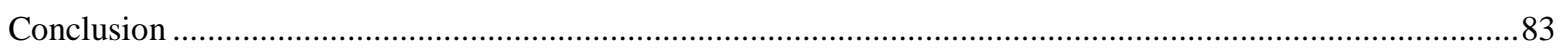

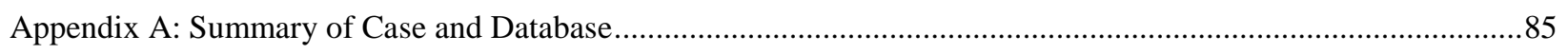

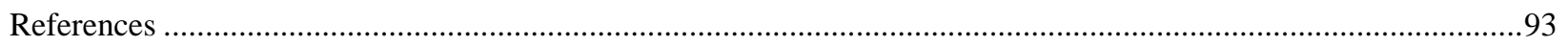




\section{LIST OF TABLES}

Table 1: Summary of results for companies in support and opposition to HB2......................40

\section{LIST OF FIGURES}

Figure 1: New Belgium Brewing Twitter Newsfeed

Figure 2: HB2 image posted by New Belgian Brewing ..................................................54

Figure 3: An excerpt of Ben and Jerry's Twitter feed..................................................63

\section{LIST OF APPENDICES}

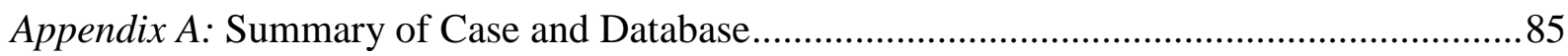




\section{CHAPTER 1: INTRODUCTION}

\section{OVERVIEW}

North Carolina passed legislation in March 2016 that required all individuals to use the washroom that matched the sex on their birth certificate, among other things. When companies made the news by boycotting the state and speaking publicly against the bill, I was taken aback by the enthusiasm with which activists greeted the commercial reaction (Smith, 2017; Helmore, 2016; Hoge, 2016). Commercial interventions in government policy have not typically attracted support from social progressives as a group, particularly where human rights are concerned. While the heart of the controversy was a very real threat of discrimination against LGBTQ individuals, the bill's passage, embattled duration, and eventual repeal raised questions about political consultation and commercial speech. Companies acted and were welcomed as speakers for groups of citizens; an action that was until recently largely restricted in practice to elected representatives and civic organisations. Closer examination of the actions of the companies involved revealed practices and rhetoric of interest to the study of political communications, the public sphere, and the political economy of social media platforms.

For-profit companies exert a level of political power that is different than elected officials or ordinary citizens. Research in this arena has largely focused on efforts to lobby and influence elected representatives, but the ubiquity of digital technology and efforts to personalize marketing have made courting social media influence through political content a widely practiced activity worthy of study. Rather than taking place behind closed doors, or even addressing legislators directly, companies present their arguments and objections publicly, frequently on social channels developed to garner attention for the brand. This turn comes during a long period of decline of 
trust in institutions. While governments have frequently provided the authority for companies to take leadership positions in public interest politics - through public-private partnerships and encouragement of political consumption and the inclusion of private sector representatives in delegations to multi-lateral institutions, among other things (Berlin, 2011; Pharr, Putnam, and Dalton, 2000; Shtern, Landry \& Raboy, 2012)—few welcome such direct interventions on issues of legislation. Regardless, by making efforts to remove themselves from states with whose policies they disagree or making public their disagreement with legislation, companies choose to publicly involve themselves in political and social controversies.

This thesis analyzes the tailoring of messages by for-profit companies in a significant case study in the U.S. using available secondary sources consisting of public statements from brands that involved themselves in the debate over North Carolina's contentious House Bill 2 (HB2). It attempts to investigate and problematize the relationships between social media platforms, social movements, and politics and policy through an inter-disciplinary approach that is heavily influenced by media and communication studies. I rely on the literature of brand relationships, digital public spheres, and political consumption to shape my interpretations. Through that analysis, I gain insight into the way companies integrate overtly political actions into their communication channels, and consider the implications of those communications for the public interest in liberal democracies. This research asks: How do the strategies used by companies to incorporate political content into their communications channels impact our understandings of civic engagement and the environment of public communications? In so doing, this project aims to contribute to our understandings of the relationships between social media platforms, commercial and advertising agendas, and contemporary politics and political activism. 
To answer that larger question, this thesis will address the following component questions, using the commercial actors that mobilized around HB2 as sources of evidence.

1. How do companies incorporate political material into their communication channels?

2. How do the responses of the companies involved compare to what is known about marketing behaviours?

3. How does this phenomenon relate to corporate speech law and practice in the U.S. and elsewhere?

\section{OBJECTIVES}

Because of its ubiquity and importance as a site both of public debate and commercial messaging, social media is a key site of analysis, along with press releases and related documents of approximately one hundred businesses that publicly reacted to the passage of a contentious bill in North Carolina. For-profit actors making overtly political moves in advance of legislative or social pressure to do so may be understood as a public relations strategy or a sign of evolving expectations of the roles and responsibilities for commercial actors in democracies, depending on how those actions are communicated to various publics. By analyzing the range of involvement, this thesis will shed light on for-profit entities' outsized importance to public interest debates in contemporary democracies.

This study necessitates serious consideration of role of online discourse. There is speculation that social media feeds might represent a new public sphere where ideas can be discussed and rational consensus reached but it is certain that digital media is now used nearly ubiquitously and its use is embedded in social relations (Bruns, 2008; Dahlgren, 2013). A legitimate public forum can only exist when participants have symmetrical opportunities to speak 
and to be heard. While there are unwritten rules, centered on perceptions of honesty and authenticity, for what constitutes legitimate online engagement, commercial actors can easily meet those requirements and become high status contributors. Moreover, commercial actors come into online spaces with existing social capital and access to a different architecture on social platforms, one that provides strategic data and tools for targeting users that are not available to most individuals. Together, these social positions and technological benefits create a powerful platform from which businesses speak and act that undermines conjectures of a neutral, many-to-many space online that could serve the public interest in communication. At the same time, it makes companies, who are profoundly attached to their reputations, vulnerable to negative attention.

Much of corporate outreach now takes place online and the proliferation of digital channels has created a need for content, along with professional standards for best practices. Content marketing strategies centre on the provision of information intended to be useful to core customers, rather than selling messages or emotional appeals, and they have been shown to be very effective at reaching online audiences (Holliman and Rowley, 2014; Pulizzi, 2012; Cevellon and Galipienzo, 2015). Corporations know they can use social media to increase positive feelings towards their brand. At the same time, they fear the effects of social media used against them enough to pre-emptively change strategies if the potential for negative publicity arises. The combination increases the importance of companies' control over their social influence. Commercial understandings of social influence refer to the ways consumer purchasing decisions are impacted by factors and individuals in their surroundings and brands' reputations in those circles. All social and political controversies involve networks of individuals, connected to both commercial actors and to political issues, able to be influenced by and ready to influence the decisions of the institutions to which they are connected. 
This thesis will investigate how topics of communication converge between commercial, political, and private actors and how that convergence signals an expanded definition of what and who can act on ideas of representation, legal protection, and institutional responsibility. It is not unusual for private companies to take actions seated in moral feeling. In the US, companies have opted out of government programs on religious grounds, as in the cases of Eden Organics and the Hobby Lobby, or refused to do business in states where controversial legislation has passed (Powers, 2016). Very recently, companies have pulled advertising from content and personalities that are controversial, essentially dictating production and HR decisions with their advertising budgets (Grynbaum and Mahashwari, 2017; Maheshwari and Wakabayashi, 2017). These moral and economic actions have precedents in organized political protests like the divestment campaign against the apartheid regime in South Africa, or the civil rights bus boycotts and, when practiced by companies, they encompass a wide variety of behaviors, including creating "green" products or donating to charities. These politically charged actions have the effect of reaching compartmentalized networks of people.

This project explores the contemporary convergence of political and economic actors in digital spaces and considers its historical roots. Anxieties about overburdened democratic institutions, accompanied by dropping confidence in government, have been present since the 1960's (Pharr, Putnam, and Dalton, 2000). Discontent with government action on social issues has turned attention to market solutions, paving the way for commercial entities to act on issues of public importance with the assurance of support from both above and below. In so doing, they confirm their role as corporate citizens, an identity that serves them well in their outreach to consumers, particularly in online media where shareable content and social capital plays an important role in what is seen and discussed. 
Earlier scholarship has explored the activist possibilities of new media, as well as its coercive and commercial aspects, but the reception of commercial actors as speakers and citizens of these digital realms, rather than as owners or subsidizers, is less well understood. Their reception may tie to larger efforts at widening the definition of stakeholders in political decision making, as well as the adoption of ideas of stakeholder engagement in commercial branding efforts. This research project will attempt to answer how certain political actions, and their communication to the public, support or undermine concepts of the public sphere, political consumerism, and stakeholder engagement, and assess the significance of for-profit enterprises as social actors, targets, and communicators in political situations. In particular, it examines how the affordances of social media recreate businesses of all kinds as media or publishing platforms with similar powers to those long associated with telecommunications companies.

I argue that calls for moral action from non-traditional political actors, combined with brands' sensitivity to issues of reputation and relationship building, have contributed to a contemporary society in which commercial entities increasingly act and are treated as institutional intermediaries between private citizens and elected officials, particularly on issues that are difficult and time consuming to address legislatively. Elected representatives hold political power in their ability to write laws, but attempts to legislate a social agenda occasionally clash dramatically with the preferences of large businesses. The central curiousity of my research is the collision between electoral democracy and commercial, cultural presences. Many of the social issues, including those surrounding the LGBTQ population, addressed by for-profit companies' activism are arguably supported by a majority of people. In the instance of $\mathrm{HB} 2$, there is some room to argue that the efforts of businesses, through the withdrawal of their investments, allowed people who were not represented by the North Carolinian legislature to have a voice, and even to win a partial victory. 
However, it is questionable to what degree resistance to HB2 is a case of a) a wider deliberation and b) an effective tactic for other political issues. There was significant commercial pressure against North Carolina, which might represent a wider deliberation than that undertaken, for instance, by the politicians that drafted the legislation. At the same time, a majority of the companies that opposed HB2 are purveyors of luxury goods that require customers with a certain amount of disposable income. Those companies and the communities that support them have more invested in LGBTQ politics and so they exerted pressure in this instance, but it is unclear how often and on which issues they might be motivated to take similar actions.

Companies reacting to the passage of HB2 in North Carolina both addressed themselves to a public or publics and identified themselves as a public - employers, business owners, investorsthat the state had to consider. Advocacy organisations became receptacles for corporate protest. The Human Rights Campaign of North Carolina represented the opposition, with more than 180 signatures and the public ire of governor Pat McCrory, and the Keep NC Safe Coalition represented supporters of the bill, claiming hundreds of signees who were anonymous because they feared public reprisal. Sometimes protest became a product. A collection of craft beer breweries in North Carolina created Don't be Mean to People: A Golden Rule Saison, documented the process on their social media feed, and donated the proceeds to LGBTQ causes (Myers and Jansen, 2016). Sometimes protest was an action. PayPal cancelled plans for an operations centre in the state, garnering both praise and recrimination from those opposed to the bill (PayPal, 2016b). The actions taken by these companies are in line with corporate strategies of content marketing and influence, strategies that have attracted the attention of theorists such as Joseph Turow and Adam Arvidsson. Their theories around the personalization of advertising and the social production of commercial value figure prominently in my approach to this project as I argue that companies 
acted as mediators of public sentiment while using the tools of content marketing to behave as publishers. As a result, civic discourse is subject to the selective norms of marketing, including audience segmentation and demand for consistent, high-quality content. What is created is an altered field of civic engagement, one that barely distinguishes between different kinds of political speakers, and which occasionally treats as interchangeable one kind of actor (a political party or formal political organisation) with another (a commercial institution).

The most significant question raised by this research is the possibility that the market actors and mechanisms trusted by many citizens to reflect their lifestyle aspirations and identities, including political identities, are those managed by marketing teams and plans that follow imperatives to expand the social influence of brands. To do that efficiently, they consider a very narrow piece of the population - those that they believe they can leverage to be core consumerswhen they frame their messages and strategies. The imperative to cater to consumer views, influence public perception of brands, and fill social media and websites with content contributes to the compartmentalization of places of public debate and flattens differences between civic questions and commercial marketing. Where rules have been made to govern advertising messages, they have most often attempted to mandate transparency so that the public can critically assess how to understand a given piece of content. But brand influence is not always a matter of deceit, companies can and do speak plainly under their own names to forge relationships with their consumers. Furthermore, regimes of disclosure do nothing to address the volume of commercial messaging on communications platforms. Historically, when communications platforms emerged as commercially significant, there have been heated debates over reconciling the public interest with commercial dominance. So far, social media has largely grappled with an inverted version of that debate - how to maximize the platforms' utility to marketers in order to make social media 
companies profitable. It is commercial entities themselves that have taken on a version of the public service role, possibly to avoid the kinds of regulations they have been subject to elsewhere. This thesis is in part an investigation of the potential and challenges of that inversion.

A larger theoretical question that hangs above this research is what exactly makes a good political intermediary. A level of empiricism is foundational to a democratic society (Delli Carpini, 2004), but marketing communications, and the ways that they are recreated in the political realm, rely on feeling. They are not meant to recruit outsiders, but to rally existing communities and engage those already invested in the worldview being expressed. Corporate plans leave no room for efforts outside of the market and may actively situate themselves between citizens and nonmarket solutions. Politics can be pragmatic, however, and anyone able to effectively amplify a political message may be able to legitimize their standing with invested communities. The same people who decry corporate involvement in lobbying for permissive tax laws, for instance, may well have welcomed the corporate backlash to HB2 in North Carolina. Commercial entities and commercial practices are indisputably vehicles for political feelings, and, if proof were needed, this case study shows that they can be powerful allies to a political cause. Among the core arguments of this thesis is that companies, for better or worse, must be taken seriously as vehicles for political and social thought.

\section{THESIS STRUCTURE}

This thesis will consist of five chapters. The first, following this overview, will review relevant literature to make a case that political action by companies represents an understudied expansion of media and publishing capabilities into sectors not typically included in research surrounding social media platforms, media producers, or citizen-activism through communication. 
It will also review industry literature and academic analysis to situate branding efforts in their historical and political context.

The second section will introduce the case in more detail, along with the methodological considerations that come with using a case study, particularly one that considers social media. It will argue that the situation in North Carolina represents an extreme case of the kind of corporate involvement that is seen frequently in lower profile events and therefore a good place from which to gather a range of different cases that can be compared. It will also argue that a case study is the best way to study corporate political communication, particularly in its early stages when it is subject to competing interpretations from marketers and academics alike.

The third chapter will consist of a broad survey of results followed by a detailed analysis of particular cases. The results section compares the kinds of behaviour seen in the data collected against expectations of corporate social responsibility. The analysis section that follows presents a typology of cases and outlines the relationship between marketing behaviours and the incorporation of political content.

The final chapter returns to questions presented in the overview, and considers how the actions analyzed in this thesis, as well as others like them, impact opportunities for communications between citizens and between citizens and their elected representatives. It outlines the major findings of the study, and concludes with a critical section examining the case as, on the one hand, an example of empowering engagement with market actors and, on the other, a damaging example of corporate messaging isolating citizens from one another and from institutions meant to represent them. 


\section{LITERATURE REVIEW}

This literature review situates the object of my research between political and communication theory and marketing practice. It makes the case that convergence between communications platforms has altered contemporary opportunities for communication between citizens and that social media magnifies and complicates the role of for-profit companies in societal communications. In effect, the literature suggests that the rise of online marketing tools, and particularly social media, has not only increased existing power wielded by media companies, and not only created a powerful new niche for platform companies such as Facebook, Twitter, and Instagram, but given companies of every kind access to similar abilities to create and disseminate content. It is a development that has profound implications for activists and advocates, who have already begun to target commercial actors as means to political ends.

\section{PERSONALIZATION AND TARGETING}

Joseph Turow's book The Daily You locates a public interest in the ways that businesses manage their relationships with their consumers, one undermined by the ability of companies to target their customers through the aggressive use of data. His most concrete concern is potential discrimination based on social position in the way that businesses serve ads alongside published content to those that they calculate to be most receptive to their messages. The potential to designate some potential consumers as "waste" and not advertise to them, or to serve certain consumers with entirely different ads than others based on data collected suggests consumer preferences could be shaped by a restricted version of reality served by those who profit from it. Businesses and marketing professionals do not ask the kinds of governance questions traditionally asked by states and journalists, and have little interest in the answers, which fall well outside of their mandates, even as they become publishers of content in their own right. States question the 
effects of new laws and norms on the quality and diversity of entertainment, news and information as well as asking larger normative questions about where citizens find their politics, identity, and ways to understand their relationship to the world (p. 69). For businesses, these questions are of interest almost entirely as a way to position the company towards its customers in the ways that are most advantageous. Fears of surveillance, manipulation, and the sorting of consumers into silos isolated by the content they view have been supported by research into cookies, tracking software, and quantitative ways of identifying consumers (Turow, 2012; Anderson, 2006; Fuchs, 2007; Couldry and Turow, 2014).

The affective relationships between consumers and their content tend to be labeled with the broad term of "trust". Marketers' feelings that consumers trust editorial content more than advertising drives campaigns towards earned media, testimonial advertising, and sponsored content. The mistrust of direct advertising and selling messages also underlies the recent rise of content marketing, a branch of marketing in which companies create and publish content useful to their consumers in the hopes of attracting attention, earning the trust of consumers, and generating repeat business. Content marketing is brand-aligned but not directly an advertisement or affiliated with a certain product, for example general home improvement advice created for and hosted on the website of a hardware store. The key concepts of content marketing are "community and values" (p. 289) and the overall goal is to achieve "trusted brand status" through "thought leadership," essentially making the company a source of expertise on issues related to the brand (Holliman and Rowley, 2014, p. 286; Pulizzi, 2012). To achieve these ends, experts recommend creating content on of-the-moment issues, using sharing as the social proof of quality of content, and avoiding selling messages. Content marketing sidesteps mediation through other publishing 
platforms with content designed to drive traffic directly to brand sites based on its relevance and interest to consumers.

Marketers' access to quantitative tools to segment online audiences has overshadowed considerations of consumers' affective responses to marketing appeals and accompanying contentdriven advertising approaches. That is, in part, because these are not primarily data-driven practices. They are technologically enabled campaigns that hope to strike an affective nerve, either through sharing or sheer usefulness to communities. These tactics rely on the compartmentalization of audiences online but may well move in the same direction that datadriven ad placement or personalized news content threatens to-exposure to very different “constructions of reality" for different kinds of consumers (Couldry and Turow, 2014, p. 1718). Couldry and Turow reserve a sliver of optimism for the ways that consumers of online content do not like to feel that they are being manipulated, and the necessity for content providers to retain their trust. While there is much enthusiasm around content marketing, it is also shadowed by the fear that newcomers producing low-quality content will reduce the efficacy of the tactic and undermine the credibility of the companies that produce it (Holliman and Rowley, 2014). The fear of losing credibility is widespread among marketers and companies and may have its roots in the history of advertising as an authoritarian presence in cultural spaces (Holt, 2002). Marketers find it necessary to demonstrate their bona fides with each campaign for fear of consumer backlash against content seen as inauthentic, manipulative, or inappropriate.

\section{CONVERGENCE}

Connective digital technology is used for everything from keeping a diary to running global distribution systems. Papacharissi (2010) bases arguments about a new private sphere on the ways that technology enables, and even encourages, the collapse of public and private boundaries along 
with geographical distinctions, a phenomenon widely referred to as convergence. She explains that the confusion of public and private is stronger on the internet, where personal content becomes public, social networks undermine localized connection, and events are doubled as they happen online and offline simultaneously. She quotes Melucci (1999) in pointing out that information flows online make the geographical location of a problem of "secondary importance" (p. 75). That flattening of geography makes any event available for online comment and people anywhere a potential audience for those comments. In the examples that I analyze in this paper, distance from North Carolina is certainly no barrier to commercial or communicative involvement. Papacharissi's analysis centres on the performance and control of reputation by individuals in the fluid space afforded by technology, but companies occupy these exact territories and have access to the same tools, and others besides, as individuals online. Wherever citizens have created communities, and technology has made those communities more visible, companies have followed, seeking to leverage group dynamics for market research and social capital.

Both technological convergence and the rise of complex branding behaviours are generally traced back to the 1960's and 70's. Fred Turner (2005) argues that virtual communities and commercialism came together in the mid-to-late 1960's with publications such as the Whole Earth Catalog. An interviewee in Turner's book describes those times as the beginnings of "alternative consumerism"- businesses such as coops and credit unions that included not only goods and services but "ways of thinking and speaking" (p. 492). Those businesses and communities began by stepping away from mainstream politics, but ultimately assimilated into mainstream life the technology and some of the working ethos of the counterculture, most notably in Silicon Valley. (A connection Turner makes explicit in the title of his book From Counterculture to Cyberculture). Douglas Holt (2002) and Adam Arvidsson (2008) identify a similar timeline in branded advertising 
and product development, with consumers becoming aware of the power being wielded by brands and rebelling against it in the late 1960's. Arvidsson argues that the interactive relationship between consumers and brands tracks the development of communications technology. First, the gramophone, television, and radio made global culture more coherent. Once that coherence was achieved, commodities worked their way into everyday life and trends diffused quickly across the globe (Arvidsson, 2008, p. 328). The faster the tools of global communication worked, the faster companies learned what was fashionable and what consumers thought of companies' current wares and campaigns. The goods being sold became more expressive, geared towards consumer tastes. It became easier to publicly display an identity or lifestyle through products and for companies to react to the political climate. Companies could build trust with their consumers by demonstrating responsibility, giving back, and contributing to a common cause while consumers created value for brand names through their use of the products. In the face of countercultural backlash and technological upheaval, brands changed strategies to create a situation in which consumption was "a volitional site of personal development, achievement, and self creation" (Holt, 2002, p. 82)— aligned with consumers "ways of thinking and speaking" - with the result that brands and branding are more prevalent than ever, but not necessarily viewed as domineering in the way that they were in the middle of the $20^{\text {th }}$ century. Rather, they are treated as valuable contributors to social life.

Optimistic theorists have viewed the rise of the web and social networking as a potentially utopian arena of radical self-expression, community-building, and talking back to power, where counter-hegemonic messaging can be incubated. Scholars of new media, such as Lievrouw (2011), Bruns (2008), Castells (2007), and Fuchs (2011) laud the ways that new media empowers organic, human networks and affective connections in media creation and development. Leah Lievrouw (2011), in particular, emphasizes new media's importance for alternative and activist projects. 
While hopes for co-creation and individual empowerment remain high, increasingly scholars, including those listed here, are skeptical towards the idea that the advent of networked technology changed societal power dynamics significantly. Blame for corrupting social networks is largely placed on commercial actors co-opting the space for profit-making, with Fuchs notably calling for class-based interpretations of digital content production and use. The internet is a medium for social connection, authenticity, and resistance, but it is also a space of accumulation (Fuchs, 2012, p. 219; Malin, 2011). The user is both a producer and a consumer, a voice and an audience. As a result, cognition, communication, and cooperation on the internet are commodified at the same time as they undercut corporate interests through social and non-capitalist forms of exchange.

One of the results is that marketing teams are extremely aware of how consumers are speaking about companies online, and work very hard to react quickly to retain the goodwill of their consumers. The measure for audience engagement was formerly total numbers, but the ability to track consumers more closely online makes it possible to identify different levels of investment in a community and to target those that are most involved. Malin's (2011) study of Facebook suggests that smaller communities create focussed attention, people that care more about the content of the group than is typical of people watching broadcast media, for instance. These pockets of affect, connection, and focused attention, are irresistible targets for advertisers, especially because groups do a significant amount of market research and segmentation simply by identifying members. Marketers approach these groups cautiously, since campaigns can backfire badly, frequently employing community managers whose job it is to understand and interact with consumers on a relatively organic level (Garrigos-Simon, Lapiedra Alcamí, \& Barberá Ribera, 2012). 
Marketers typically associate the rising visibility of consumer groups and their ability to punish brands for missteps as making the consumer "king" (Boothe, 2016, para. 1) and forcing all brands to put service ahead of other concerns. The converse argument is that social media sites are places where people proactively court their own place as subjects to systems of capital. Coté and Pybus (2011) see a qualitative shift where culture, subjectivity, and capital merge around affect and the "logic of capital" flows through a widening swath of otherwise discrete social relations (p. 10). To them, the continual updating of one's online presence "suggests an intensifying need for valorization or recognition in the newsfeed." (p. 6) Not to do so risks losing one's "legibility" to the greater community (p. 6). The desire for legibility does not only apply to individuals, but is also felt by brands and their marketing teams, which are peppered with imperatives to update their content constantly, and to provide their consumers with useful information, hence their feeling that the consumer has taken control. Consumers, however, do not share brands' architectural advantages online since platform companies are willing to facilitate brands' ability to serve their content to targeted audiences in pursuit of profitability through marketing dollars. While both consumers and brands wish to be legible in their social media channels, companies enjoy advantages in their access, as well as their existing social recognition.

Even cooperative spaces online, such as the major social media platforms, are either aligned with motives of profit or they are hybrid spaces that are partially cooperative and partially profit-producing in nature (Fuchs, 2012). On social sites, attention is diffused through the posts of people you know and pages you choose to follow. However, the numbers show that people spend most of their time on the internet on content originally created for broadcast media. In addition, social channels use data to curate the materials people see, often to privilege content created by advertising partners (Sullivan, 2017). It can be argued that the convergence between the private 
lives of individuals and the public debates and actors is not necessarily a problem but instead a new model of social life, with individuals moving in between personal, commercial, and public content seamlessly and incorporating branded content into their identities in critical, reflexive ways. The degree to which that might be true is taken up, in online contexts and off, by scholars of political consumerism.

\section{POLITICAL CONSUMERISM}

Political consumerism is the deliberate purchase or avoidance of goods based on political or moral convictions - buying environmentally friendly products, for instance, or boycotting tuna that is not explicitly dolphin friendly (Stolle et al., 2005). While instances of political consumerism go back to the turn of the $20^{\text {th }}$ century, there are reasons to believe that social media has facilitated the practice. Becker and Copeland (2016) used survey data on LGBTQ individuals who use social media for connective purposes, such as to be part of a wider community, and found those individuals more likely to participate in political consumerism. That finding held true whether or not the individuals were highly interested in politics to begin with. They did not find that general use of social media contributes to offline participation, but that more specific, connective use, was predictive of higher levels of participation. Their findings are, no doubt, well known to PR representatives and social media strategists. There is clear motivation for companies to not only to monitor the concerns of such connected communities but to actively manage the reception of their brand messages in them. Both Stolle et al.'s survey on political consumerism and Becker and Copeland's study found individuals who participated in the practice distrusted institutions, including international institutions, and believed that purchasing practices can have an impact on the decisions of large commercial entities. Additionally, there is evidence that political consumers are motivated by domain-specific dissatisfactions, i.e. frustration about a single issue or topic, 
rather than an entire government (Berlin, 2011). The rise in political consumerism may well be predicated on a decrease in faith in political institutions to address specific concerns; a decrease that leaves private businesses as the recipients of politically charged engagement with consumers eager to vote with their wallets.

Scholars such as Adam Arvidsson $(2008,2009)$ see potentially revolutionary practices stemming from politically motivated consumption. He argues that the accessibility and widespread use of social media platforms, including their use by commercial entities, will lead to the value of companies being rationalized through their social worth, rather than their straightforward profit margins. He envisions Thai seamstresses live-tweeting their working conditions, leading to social backlash that forces companies to change their policies. He calls that process a social production of value, one that does not maximize economic gains directly but that capitalizes on the financialization of social processes. In a sense, social worth would rationalize economic power in the way that scholars of the public sphere argue that communication could rationalize political power. Arvidsson suggests that having information readily accessible will force companies to follow through on promises of sustainability or labour conditions for fear of backlash against their reputation. He is joined in that opinion by scholars of political consumption and corporate citizenship such as Micheletti and Stolle (2012). His work predicts companies taking public stands about their own products and policies, and even transforming capitalism, but does not provide details on how companies might interact with legislation, exert pressure on elected representatives, or legitimize activism through reference to specific stakeholders rather than general moral concepts.

Corporate Social Responsibility, StakeHolders, AND Brand AdVOCATES 
Both brands and governments have embraced stakeholders as means to integrate the concerns of a range of actors into decision-making. In branding, stakeholders can be ranked based on their interest and power. Those with higher levels of power or interest must be engaged in more significant ways than those with less of either (Gregory, 2007). Those stakeholders can include governments and their agencies, civil society actors like NGOs and activist groups, as well as broader sections of the public such as customers. The specificity of stakeholder dissatisfactions makes it possible for any actor to be seen as legitimate if it steps in to solve a problem, making space for seemingly unrelated companies to take on powerful roles on institutional and social issues. Corporate consideration for major stakeholders make it possible for commercial actors to identify groups and address their concerns as a way of reaching commercial goals.

Alongside stakeholders as a logic of consultation and co-creation, brands have emerged that closely mirror the values of their customer base in ways that go beyond the PR department. As mentioned earlier, the 1960's and 1970's gave rise to new ideas and skepticism towards advertising and commercialism. The resulting countercultural movement included NGO's and experimental cooperative ventures of many kinds, but along with the protests and attempts at radical departure from previous ways of doing business, there were a number of boutique profitoriented operations that incorporated the ideals of the time. Businesses like Ben and Jerry's ice cream, The Body Shop, and Patagonia built their reputations on quality, but also on ideas of citizenship. At the time of their founding, these businesses walked a line between progressive or radical politics and the demands of business. They also created niche customers invested in their brand's products, but also their social and moral practices. They are early practitioners of formalized corporate social responsibility (CSR), a display of public morality practiced, at varying 
levels of sincerity, by the majority of large corporations today (Hendry, 2006; Holt, 2002; Arvidsson, 2009).

Expectation and implementation of CSR vary widely between individual companies and information on how decisions are made is often secret and not empirically tested (McWilliams and Siegel, 2011). Regardless, CSR is extremely prevalent, if not ubiquitous, among large companies. There is empirical support for firms benefitting financially, and in labour relations, from a reputation for social responsibility, though they must continually battle skepticism among their consumers (Sharfman and Fernando, 2008 in McWilliams and Siegel, 2011). In complementary research, Cervellon (2012) has shown that firms comply with demands of environmental nongovernment organisations to pre-empt damage to their reputation with their consumers. Online, the stakes for corporate reputation are as high or higher as social media platforms facilitate mobs and the "logics of aggregation", often aimed at corporate offenders (Juris, 2012, p.260; Rheinhold, 2003). As a result, companies calibrate and recalibrate their causes and messaging to maximize their perceived sincerity with their customers and to stay ahead of public backlash. One of the most effective ways to reach that goal is to cultivate loyal stakeholders-or "experiential co-creators" (Ramaswamy and Ozcan, 2016) — who will act as brand advocates, defending the company with minimum prompting from management (Fisher and Vallaster, 2008; Foster, 2014; Fontein, 2016). That kind of grassroots identification with and defense of brand actions is one of the many reasons that companies find it valuable to integrate themselves as closely as possible with the emotional lives of their core consumers. It also complicates attempts to check political speech by corporations, though those attempts have had very little legal traction, historically.

\section{CORPORATE LAW AND CORPORATE SPEECH}


In the US freedom of corporate speech has resisted limitation because legal rulings tend to enforce interpretations that it is speech itself that is protected, rather than individual speakers. The comparison made in these cases is between commercial corporations and individuals, rather than commercial corporations and governments, whose speech rights are much more limited, for fear of abuses of power (Greenwood, 1998; Winkler, 2006). When corporate speech is tested against freedom of speech rights, typically the court finds in favour of more speech because it is equated with more information, supporting an understanding that marketing is providing a public service by informing citizens, rather than taking space from other types of speech or manipulating consumer behaviour. Hobby Lobby, which was the focus of a court case around religious freedom and corporate speech that ultimately favored the rights of the closely-held company, helped to cement the rights of companies to pursue activist agendas in a U.S. context, even in the face of federal legislation (Horwitz, 2014; Meese \& Oman, 2014).

Where thinkers have linked corporate speech and CSR efforts, they have done so through examples of corporate lobbying or relationships between multinational corporations and the governments of developing nations (Banerjee, 2008). When corporations use stakeholder approaches to corporate planning abroad, often they are criticized as wielding outsized power to discipline populations, forcing them to follow a neoliberal paradigm. This position exists alongside arguments that companies require social license-or the support of influential elements of society—in order to continue to operate effectively (Gunningham, Kagan \& Thornton, 2004). Arguments against unlimited commercial speech suggest that corporate speech should be limited in the ways that governments' speech is limited because the power differential, in terms of wealth and organisation, between the speaker and the citizens could distort communication. A power differential may be reinforced by the architecture of social media, which gives companies an 
advantage in reaching exactly those that they wish to target. Perceptions of corporate manipulation may be undermined by the ability of social media users to affect the reputation of corporations through widespread, public condemnation, as witnessed in recent examples including the resignation of Bill O'Reilly from the television show that he hosted and the removal of a Pepsi ad widely seen as wrong-footed. ${ }^{1}$

It is common for critics to credit Citizens United with removing the last limitations on commercial speech, but it is more accurate to say the case removed barriers to corporations encouraging citizens to vote for or against certain political candidates (Levitt, 2010). Critics of corporate speech typically invoke the use of the fictional shareholder (a legal fiction designed to encourage corporations to maximize profit) to argue that commercial corporations cannot speak freely in the ways that citizens speak (Greenwood, 1998). Critics also argue that the lack of reasonable limitations on corporate speakers impedes the ability of private citizens to be heard. However, providing political content to supporters through corporate publishing platforms creates no legal challenges for businesses.

\section{Public ANd Representative Public Sphere}

Corporate speakers, content marketing, and brand advocates challenge models of public communication that rely on independent, publicly-interested publications such as newspapers, radio, and television as well as those that see the internet as a place where communication between citizens is disintermediated, allowing for direct engagement between citizens in a new public

\footnotetext{
${ }^{1}$ Bill O'Reilly, host of the Fox News program The O'Reilly Factor, resigned from his position after companies refused to run advertisements on the program. O'Reilly was accused of a number of cases of sexual harassment, many of which had been settled by his employer (Grynbaum \& Mahaswari, 2017). Pepsi created an ad that appeared to trivialize protest over systemic racism in the United States. The ad, which featured Kendall Jenner making peace between two sides of a protest by distributing cans of Pepsi, was taken down within hours amid public outcry (Victor, 2017).
} 
sphere. Theories of the public sphere and communicative action originate with Jurgen Habermas, who envisioned modern people as autonomous, capable of self-reflection, and, therefore, capable of objective discourse that could rationalize power relations (Habermas, 1989; Alvesson and Skoldberg, 2009). Crucially, Habermas believed that communication is reciprocal and that through rational discussion there is a possibility for mutual understanding and even consensus. Reciprocal communication does not imply that every opinion carries equal weight or is equally correct. Participants must be able to question the basis for validity and the status of a claim of knowledge or experience and the scope and reliability of knowledge must be ascertainable to the other parties involved in the act of communicating. The roots of ideas must be accessed and understood by all and asymmetries in knowledge of events must be made even for good communication to have taken place. That mutual recognition of the roots of a dialogue is the foundation of Couldry and Turow's (2014) concern, from the beginning of this literature review, about the way that datatargeted advertising could undermine shared "constructions of reality" (p. 1718). Habermas argued that the public sphere, instantiated in the salons and newspapers of $19^{\text {th }}$-century Paris, was undone in part by the self-interest of commercial actors that coopted the space for financial gain (Habermas, 1989). His consideration of the ways that individuals turned towards family and the home (the private sphere) is taken up in modern contexts by Zizi Papacharissi.

The high standards of rational-critical argument asked of individuals has been the undoing of widespread acceptance of theories of the public sphere and communicative action. Some theorists have attempted to alter the theory to account for and legitimate institutional methods of representing rational discourse for the public or the incorporation of more complex forms of individual engagement. Trenz (2009) theorizes a representational sphere facilitated by the media to bring a multiplicity of viewpoints to be debated in front of the public. Even in a representative 
public debate, viewpoints are meant to be argued in a mutually recognized space to maximize objectivity. If one considers, as this thesis does, developments in brand marketing and political consumerism positioning companies as proxies for citizens' political opinions, the possibilities of who may be representing the population in public debates expands well beyond media outlets, even when one considers a media expanded by the powers and perils of social platforms.

Zizi Papacharissi, in her book A Private Sphere (2010), addresses hope that the internet would provide a virtual public sphere, which she evaluates in terms of access, reciprocity, and commercialization. She finds, however, that virtual communication is dominated by a small number of individuals. While online conversation being dominated by a few is significant, and itself intricately tied to marketing efforts (Shtern, Branche, Hill, \& Chan, 2017), it is the role of commercial actors that I want to home in on. The commercialization that Papacharissi, following Habermas' critical perspective, identifies is perpetrated by media companies. She contrasts the social ties of networked individuals with media content to argue that social ties might provide a viable alternative to media narratives. That focus sidelines the powerful influence exerted by nonmedia companies online, where their existing social capital and name recognition allow them to quickly amass followers and to focus eyes on the content that they produce, not simply products but editorial and marketing materials (Holliman and Rowley, 2014). Trenz' analysis similarly focuses almost entirely on media companies as containers for diverse public opinions, carrying out debates on behalf of populations that they represent. When he talks about the internet, it is in terms of its ability to support media companies in this capacity, not in terms of the ways it enables private companies of diverse kinds to step into the role of representational vehicle, binding consumers closer to them through political feeling. Work on social enterprises, fair trade, and political consumption meanwhile, has long paralleled social movements and profit-making enterprises 
under the mantle "market citizenship" (Youde, 2009, p. 209) and "green" companies have spoken on behalf of their customers for years. The analytical tools and publishing platforms provided by the development of digital technologies have made that kind of advocacy easier and less risky for companies whose marketing teams can now forecast the way their efforts will be received and adjust content to optimize reactions from key stakeholders.

SUMMARY

This literature review has highlighted personalization, the convergence between the social and political on digital platforms, contemporary marketing practices, and their relationship to the public sphere. The ways that online communities focus attention through emotional messaging and digital publishing platforms bring together formerly disparate social and political channels. In that environment, brands both seek and become the target of calls to integrate aspirational, ethical, and lifestyle ideas. A social controversy such as the passage of HB2 provides a platform where these currents come together around an important civic question, straining conceptions of who is a legitimate speaker and what constitutes public debate. 


\section{Methodology}

The conceptual questions asked by this research stem from practices at work in the real world. It follows that investigation of the trends that I have identified must have a significant empirical dimension. This research uses the case study of a contentious piece of legislation in North Carolina to explore how political content was incorporated into the public profiles of forprofit companies. The reactions of individual companies to the controversy were examined to provide a body of evidence of contemporary marketing practices and a typology of commercial reactions was created that could be compared to academic and industry models of marketing and branding. The comparison provided insight into the ways political content is used in marketing practice. While the context is unusual-HB2 clashed with the social agendas of more companies than is typical of legislation - it provided a cohesive group of reactions that I believe to be representative of the practice of integrating political content into channels of corporate speech. This section presents the significant features of case study research along with major considerations for social media research. This section also includes details of the case itself, and the procedure used to collect data.

Robert Yin (2003) introduces the case study as a method best suited for empirical inquiry into "a contemporary phenomenon in its real-life context, especially when the boundaries between phenomenon and context are not clearly evident." (p. 13). Content created in reaction to legislation, meant to be read by consumers alongside more innocuous branded content is precisely the kind of contemporary, real-life phenomenon that case studies are best suited to assess. Case studies rely on the use of different sources of evidence to give a full illustration of the patterns at work. Because they have the potential to become large and unwieldy, they benefit from using clear theoretical positions to guide data collection and analysis, though there is a risk of either diverging from the 
original questions or ignoring evidence that contradicts the theoretical perspective the researcher had when approaching the project. Both risks can be ameliorated by clear statements of purpose and criteria for success. In this case, it was known beforehand that at least some companies had incorporated HB2 into their social feeds and the question was rather how they did so and how it compared to normative expectations for commercial feeds. While I have chosen to approach this controversy as a case study, it is worth a brief digression to consider controversy mapping, an approach associated with actor-network theory, frequently used by analysts of contentious issues discussed on social media platforms, and useful when considering how to gather and interpret data online. While this research methodology has an eye towards controversy mapping as practiced by researchers of online issue publics, it cannot be considered an application of that methodology.

Controversies are complex and dynamic by nature and a method that accounts for the inevitable conflicts and contradictions of the situation being observed is necessary to avoid oversimplifying the situation. Jean Burgess (2016), Burgess and Sauter (2015), and Marres and Moats (2015) have written on the suitability of online controversies as research sites for mapping issues. Scholarship that maps issues on digital platforms typically collects data from Twitter or other social media sites, cleans it of corrupting influences, including automated accounts, and analyzes it for significant patterns and notable actors. This approach produces a quantitative reading of online controversies, designed to reduce bias and make full use of the visibility of online networks. The approach is primarily used to make arguments about social media as a venue for political conversation, hashtags as identifiers, and links as discourse. In other words, researchers employing this method use an issue map of a controversy as an occasion to study social media and its affordances. Burgess and Matomores-Fernandez (2016) note in their work on Gamergate that powerful analytical tools are invaluable for understanding "born digital" controversies (p. 79), but 
I would add that they are not always suitable for a controversy that extends to the offline world or even for controversies that span multiple platforms. For instance, their research on Gamergate only revealed that Anita Sarkeesian, an important figure in the controversy, did not make use of Gamergate hashtags when her social media feeds were closely read by the researchers. Without qualitative analysis, important insights can easily be missed.

Messaging and its reception are the focus of this project and they direct the form that the collection of data and its analysis took. Many of the actors in my research are in conflict, with each other and with political opponents. Their statements are often explicitly responding to the statements made by others online and off. While I am sensitive to the use of language, the emphasis remains on what is said, rather than the nuances of how it is said. I have made extensive use of public documents produced in the controversy surrounding HB2. These documents include legislation, blog posts, press releases, press interviews, and social media feeds. The plethora of digital materials provide evidence of the ways in which these companies wish for their actions to be presented to the public and provides meaningful sources of information on which stakeholders businesses consider relevant to their public stances. Online sources like those that I am using blur the lines between document collection and direct observation and provide ancillary materials, including interviews, that aid in triangulation towards my research questions. Though this is not a quantitative analysis, I keep in mind some key factors in Burgess and Matamoros-Fernandez's research method (2016), namely temporally representative sampling and consideration of forms, genres, and platforms (p. 82).

The study of platforms requires further explanation. Because my project examines online discourse, it necessarily overlaps with the study of the platforms on which that discourse occurs. Plantin (2015) and Gillespie (2010) show that platform features are far from neutral - they shape 
the kind of content that is produced. Whether a company chooses to make a political stand a part of its branded newsfeed, to speak to the press separately, or to be spoken for by another organisation, what they say is shaped by the kind of interaction that is available on their chosen platform. Analyzing those differences is an important step in a situation where public perception is shaped by online reading and reception and direct interactions on online platforms. Twitter, in particular, has become an important site for branding activities by companies (Brennan and Croft, 2012; Greer and Ferguson, 2011; Jansen, Zhang, Sobel, and Clowdberry, 2009). Twitter is a useful site of analysis because it played a role in the public unfurling of the HB2 controversy, because it is increasingly used to source public comment, and because it is used as a branding tool by a significant number of the companies featured on the Charlotte Observer's list of those opposed to the bill. Essentially, Twitter was used to distribute political speech about HB2, either in the form of short statements of support or opposition or by way of links to more detailed statements hosted on company or media organisation websites.

\section{PROCEDURE}

I used a relatively comprehensive list, compiled by the Charlotte Observer, of businesses that took positions either in favour or in opposition to HB2 to guide my data collection. I have limited my data collection to the time period between March $23^{\text {rd }}$, when HB2 was passed, and May $9^{\text {th }}$, when the State of North Carolina counter-sued the federal Department of Justice over accusations of discrimination, effectively entrenching their position and prolonging the conflict into the 2016 U.S election and beyond.

To analyze the public discourse of companies and their representatives in the controversy around HB2, I followed the procedure below. 
I used the list identifying publicly implicated businesses published by the Charlotte Observer as a guide to which companies to investigate. The newspaper is local to the state and was referenced by some of those who commented. The paper is owned by McKlatchy and has been in operation since the late 1800s (charlotteobserver.com, n.d.). It followed the controversy around HB2 closely, reporting on the bill's opponents and supporters, as well as the larger context. The list, published April $18^{\text {th }}$ after an executive order adjusted some of the bill's language around discrimination and continuously updated during the year, identifies more than 60 supporters of the bill, and more than 180 opponents. I have analyzed an approximately equal number of actors on each side, covering almost every business supportive of HB2 and an approximately equal number of those opposed for a total of 96 actors. I could not verify every company present on the Charlotte Observer's list, so the total numbers examined are not equal to those on the original list. To collect a sample of the companies opposed to HB2, I selected the companies in the order that they appeared on the list, except when a company was emblematic of the controversy, as in the case of PayPal, or when a company that appeared earlier in the list was part of a larger group, as in the case of the North Carolina craft brewers. By using a list compiled by the newspaper the Charlotte Observer and examining their reactions over the same period, this thesis provides a comprehensive accounting of the strategies employed by companies that reacted to the controversy.

For each identified actor, if possible, I examined their social media presence, including Twitter and Instagram, company blog, their presence or absence from open letters to the office of the governor of North Carolina, including one in opposition organized by the Human Rights Campaign and one in support, organized by the Keep NC Safe Coalition. I also conducted a keyword search for any public comments made by the company about HB2. In so doing, I amassed a collection of documents and statements positioning commercial actors around the bill. I created 
a spreadsheet identifying the companies, their size, the names of the individuals that signed on their behalf, the position of the company in regards to the bill, the mediums in which they made their position known, the presence or non-presence of comment on the bill in their social media feeds, a general description of the contents of their publicly available feeds, the location of their headquarters and, where available, the presence or non-presence of significant holdings within the state of North Carolina, and any general notes about their behaviour, along with URLs for referencing the location of relevant content. That spreadsheet made obvious remarkable differences between the companies that supported HB2 and those that opposed it in terms of size, location, and use of social media. The first portion of the results chapter draws directly from this spreadsheet (see Appendix I for detailed summary).

In total, I examined 96 companies in detail, 42 of which provided materials beyond signing the open letter of either the Human Rights Campaign or Keep NC Safe Coalition. The materials examined included 77 social media posts, some of which included videos or long essays, 14 blog posts, 13 interviews in news outlets, 2 letters to the editor and 1 crowdfunding essay. My analysis prioritized materials created and disseminated directly by the companies, though in some cases, such as the entertainment companies, what was not created or disseminated was important. I then identified cases with similarities, creating a loose typology of reactions to the bill. I examined what I consider exemplary cases in more detail, using other cases of the same type to support my conclusions before drawing comparisons to theoretical expectations. The next section of this chapter introduces the context surrounding the passage of HB2 and the reactions of the companies examined. 


\section{NORTH CAROLINA’s HOUSE BILl 2}

On February $22^{\text {nd }}$, the city of Charlotte, North Carolina, passed an ordinance that added gay and transgendered people to the list of groups protected from discrimination (Lacour, 2017). The ordinance was due to take effect April $1^{\text {st }}$, but the state legislature quickly convened a special session wherein they passed legislation to pre-empt the ordinance from taking effect. On March 23, that legislation, largely known as House Bill 2, HB2, or the bathroom bill was passed (Socarides, 2016). The bill was signed into law by Republican Governor Pat McCrory shortly before midnight. The bill made it mandatory for people to use the bathroom that corresponds with the gender on their birth certificate, as well as limited the ability of regional and municipal governments to set minimum wage laws, among other things (Douglas, 2016). Critics derided the law as the latest iteration of the religious freedom bills passed (and sometimes vetoed or repealed) in Indiana, Georgia, Tennessee, and Mississippi that broadened the abilities of private companies to refuse to provide services based on religious convictions. HB2 similarly singled out LGBTQ populations and made their access to certain areas and services a matter of the discretion of private businesses (BBC, 2016). In his public comments, however, Governor McCrory denied the similarities and framed the bill as a response to government overreach by the city of Charlotte. Within hours, companies took to social media to voice their disapproval, and shortly afterward businesses began to announce boycotts and economic measures that removed investments from North Carolina.

North Carolina was considered a centrist, and sometimes progressive state, by the standards of the American South, for much of the $20^{\text {th }}$ century. By 2012, Pat McCrory, a republican and former mayor of Charlotte, had been elected, along with veto-proof Republican majorities in both houses (Kardish, 2014). Citizens of the state are relatively equally divided between support for the 
republican and democratic parties (CITE). As in other parts of the US, the more progressive populations are concentrated in the cities, with rural areas home to more conservative voters (Kron, 2012). That urban-rural split provides a backdrop to conflicts like the one over HB2, where a progressive urban area passed an ordinance that conflicted with the preferences of elected officials that primarily represented other parts of the state.

Part of the outrage surrounding the passage of HB2 focused on the perception that North Carolina was a business-friendly state. North Carolina has been a frontrunner in economic performance for much of the last half-century, and has instituted preferential tax measures designed to encourage investment (Kardish, 2014). Economically liberal policies were not only claimed by boosters of the state, but frequently referred to in puzzled terms by those businesses protesting the passage of HB2 (Wallace, 2016; Research Triangle Region, n.d.; Craver, 2016). While North Carolina itself is socially conservative, the businesses that it courted have clearly expressed preferences-more than $66 \%$ of Fortune 500 companies have written antidiscrimination policies that include protections for transgender employees (Zillman, 2015). Governor McCrory had some reason to believe that opposition to HB2 would be limited. The religious freedom bills passed in Indiana and Arkansas were also greeted with boycotts, but remained on the books, with minor adjustments. In addition, many boycotters eventually returned to the states and the authors of the bills kept their positions (Socarides, 2016). The relative ease with which similar bills were received may account for McCrory's indignation when defending the bill in the press.

In the announcement and defense of the bill, governor Pat McCrory set the terms by which he wished the legislation to be understood. The bill was intended to prevent "government overreach" by the city of Charlotte, it was designed to protect the "common sense" traditions of 
privacy, and defend the right of private businesses to set their own policies about the use of their washrooms and locker rooms. It is ironic, then, that within hours the bill was being held up by its opponents as a damaging example of government overreach into the privacy of individuals and came under fire most visibly from private businesses, many of whom made a public display of their opposition to the bill.

Pat McCrory announced the passage of HB2 through a press release and appeared in the press on multiple occasions afterward to defend the bill as the conflict became a major news story. His media appearances attempted to change the narrative surrounding the bill and defend the view that government has extremely limited rights to intervene in affairs outside of certain issues. The press release launched by McCrory's office upon passage of the bill claimed that municipal governments were responsible for "police, fire, water and sewer, zoning, roads, and transit" and very little outside of those functions (McCrory, 2016a, para. ). It also called the Charlotte ordinance a "breach of privacy and basic etiquette" (McCrory, 2016a, para. ). As the backlash against HB2 picked up momentum, the governor's office passed an executive order to adjust the parts of the bill that had been singled out by opponents - the language that denied people the right to sue in the case of discrimination. The executive order inserted protections for sexual orientation and gender identity but did not change the requirement for bathroom use or the limits on municipalities' ability to set certain laws.

Backlash to the bill found its voice in CEOs of large companies as much as from private citizens concerned for civil liberties. The cancellation of a PayPal operations centre in Charlotte, North Carolina, as well as the relocation of an NBA game and a Bruce Springsteen concert raised the profile of the conflict in the media. Governor Pat McCrory stood by the legislation, doggedly insisting that the bill was not discriminatory and not a religious freedom bill. The controversy 
spanned legal suits and countersuits between the state and the federal Department of Justice, as well as the U.S. election in November 2016, in which governor McCrory was defeated. He was replaced by Roy Cooper, a democrat that promised to repeal HB2. The legislature remained majority Republican however, and they made headlines by trying to strip the office of governor of many of its powers before Cooper took office (Omar, 2016). Regardless, the first attempt to repeal HB2 was made in December 2016. It failed, despite the city of Charlotte repealing the original anti-discrimination ordinance in an attempt to compromise with state republicans (Lacour, 2017). The controversy ended with the passage of HB142 on March 30, 2017, which removed HB2 from the books, but also limited regional governments' ability to regulate bathroom use (Fausset, 2017). The compromise pleased few.

\section{CORPORATE BACKLASH}

The first company to announce a boycott was PayPal, swiftly followed by companies such as Apple, Instacart, Bank of America, and over 200 others by May $2^{\text {nd }}$ (Peters, 2016). Companies were not the only ones to react to the bill. Performers, including Cirque du Soleil and Bruce Springsteen, boycotted the state, while others, such as the Dixie Chicks, continued to perform, but used their concerts as platforms to speak against the bill (Sorenson, 2016). Professional societies moved general meetings, or made public announcements, and states, including Washington and Vermont, let businesses know that their money was welcome in other, less embattled, more LGBTQ-friendly, places (Inslee, 2016; CBC News, 2016). Some businesses later filed a friend of the court briefing to support legal efforts against HB2 (Weissner, 2016). The story, in the legislature and the media, focused on the financial impact on the state and whether it would force a repeal of the bill (Jurney, 2016; Killian 2016; Craver, 2016). Traditional political intermediaries, such as non-profits, where quick to capitalize on that narrative. 
The non-profit organisations Equality NC and The Human Rights Campaign were the organisers of an open letter of opposition to the bill that became a focal point of the controversy, signed by the CEOs of many of the organisations mentioned above. The Human Rights Campaign also organized legal challenges to the bill, which were unresolved at the time of the bill's repeal. Their letter stresses that companies, the United States, and "the overwhelming majority of North Carolinians" (HRC \& Equality North Carolina, 2016, para. 1) do not share the values represented in HB2. The letter goes on to make the case that HB2 is a poor decision from a business standpoint and that it will discourage investment in the state. The letter provided a record of powerful organisations that opposed the bill and a source of news for media organisations covering the bill. In reaction, non-profits that supported the bill, including the Civitas Institute, the Christian Action League, the NC Values Coalition, and others (keepmyncsafe.org), formed the Keep My NC Safe Coalition and published a rival open letter of businesses that supported HB2. In their letter, they voice support for the governor and iterate the perceived financial risks of Charlotte's original legislation, including exposure to "punitive fines", "actual jail time", and "ruinous lawsuits" (Keep NC Safe, 2016). They also refer to a risk to the "safety and privacy" of employees and customers, particularly women. The post that introduces the letter was particularly concerned with the moral burden being put on the owners of small businesses. Their signatories are mostly small businesses, including sole proprietor businesses and tradespeople, in striking contrast to the multi-national, publicly traded corporations that figured prominently in the HRC and Equality NC letter.

\section{CONCLUSION}

North Carolina's Republican legislature holds most of the political power in the state, in terms of the ability to write laws, but its attempts to legislate a social agenda clashed dramatically with the preferences of large businesses. This project has produced a qualitative reading of publicly 
articulated positions by companies and public actors that have implicated themselves in the controversy through public statements. Creating a typology of those public reactions, along with in-depth readings of significant examples, yields insight into political controversy in a time of ubiquitous commerce. The research will be able to answer questions of how companies position themselves towards the public and provide empirical evidence of strategies employed. This research will lay a detailed groundwork from which to make provisional conclusions about the role companies claim for themselves in public mobilization around social issues, as well as providing a foundation for future studies. 


\section{CHAPTER 2: RESULTS AND ANALYSIS}

\section{RESULTS}

This chapter summarizes the findings of my examination of those companies the Charlotte Observer listed as having taken a position in support or opposition to HB2. The first section looks at the businesses broadly, comparing these reactions with what we might expect from developments in corporate social responsibility and marketing practice. The second section isolates instructive cases to advance an argument that commercial involvement in the North Carolinian controversy applies the norms of content marketing to the political situation, extending marketing behaviours into territory that brings together the commercial, political, and social in ways that have repercussions for communications as part of the public interest.

If we considered business reactions to $\mathrm{HB} 2$ as acts in line with Corporate Social Responsibility (CSR) behaviour, informed by histories of brand-consumer relations in the marketplace, we would expect to see large, nationally recognizable brands, reacting to issues that fit with their brand image and products, align with their major stakeholders, and appear to be noncommercial (or not directly commercial) (Holt, 2002; Gill, 2008; Lee, 2008; Lindgreen and Swaen, 2010). For the most part, the controversy around HB2 meets those expectations. Smaller companies play a more significant role than might be anticipated, however and the avenues through which companies published their reactions are telling of who businesses consider to be their key stakeholders. Table 1 (below) summarizes the results. Significant case studies will be addressed in the next section. 


\begin{tabular}{|l|r|r|r|}
\hline & Oppose & Support & Neutral \\
\hline $\begin{array}{l}\text { Number of } \\
\text { Companies }\end{array}$ & 52 & 43 & 1 \\
\hline $\begin{array}{l}\text { Publicly-traded } \\
\text { companies }\end{array}$ & 22 & 1 & 1 \\
\hline $\begin{array}{l}\text { Benefit } \\
\text { Corporations }\end{array}$ & 10 & 0 & 0 \\
\hline $\begin{array}{l}\text { Headquartered } \\
\text { Out of State }\end{array}$ & 38 & 1 & 1 \\
\hline $\begin{array}{l}\text { Announced stance } \\
\text { on website, social } \\
\text { media, or industry } \\
\text { publication HR or }\end{array}$ & 20 & & \\
\hline $\begin{array}{l}\text { Signed HRC } \\
\text { Keep NC Safe } \\
\text { letter for }\end{array}$ & 45 & 43 & 0 \\
\hline $\begin{array}{l}\text { Had social media } \\
\text { platform } \\
\text { company }\end{array}$ & & & \\
\hline
\end{tabular}

Table 1: Summary of observations on companies in support and opposition to HB2

SIZE

The companies that took public positions against HB2 are conspicuously larger and more likely to be publicly traded. Of the 54 companies on the list that are opposed to the bill, 10 are not publicly traded and not extremely large, well-known, and multi-national. In addition, there are more than a hundred companies beyond those analyzed here on the list collected by the Charlotte Observer, and nearly all are recognizable national or international brands. The difference is evident and gives some context to former governor Pat McCrory's claim that transgender washroom use as a political issue was being pushed by national and corporate backers (McCrory, 2016a; 
Sorenson, 2016), rather than North Carolinian legislators. Be that as it may, HB2 was a countermeasure to a municipal ordinance passed by the city of Charlotte, so while large companies no doubt involved themselves in the controversy once it began, the bill and the ordinance it countered are both homegrown. Smaller companies, including craft beer brewers, dentists, and credit unions provide an interesting counterpoint to the large brands that make up the majority of the opposition. The companies that publicly oppose the bill are, in most instances, companies that are large enough to have dedicated marketing departments and a customer base that crosses the nation. They are also large enough to be the targets of campaigns encouraging leadership on social issues. Several of these companies have been the targets of campaigns by groups like GreenPeace and Sum of Us, non-profits that specifically pressure companies on behalf of social and political causes (Sumofus, 2017; Greenpeace International, 2014).

The companies that took public positions in favour of the bill are generally smaller and almost completely local to North Carolina. The 46 companies on the list of supporters of HB2 include only one publicly traded company and a high percentage of sole proprietor operations (Sorenson, 2016). The largest companies on the list are XG Technology, which is publicly traded, though the signer, Reese Cao, does not appear to hold a management position within the company; Benham Real Estate Group, of which much more will be said later; Sunbelt Packaging, and Snyder Packaging. Of those companies, only the Benham brothers, of the Benham Real Estate Group, commented publicly on the bill outside of signing the NC Values Coalition letter.

\section{TYPE OF BUSINESS}

The companies that opposed HB2 publicly represent diverse industries, but are particularly clustered around technology ( 8 companies), finance (6 companies), and entertainment brands (4 companies), as well as pharmaceutical companies. There are two food related business, Ben and 
Jerry's Homemade Holdings Inc. and Cabot Creamery, both of which are certified B Corporations. A pair of North Carolina craft brewers stand out for representing a substantial group of their peers (43 businesses total) in a niche industry, and campaigning against the bill in a public and demonstrative way.

Ten of the 52 businesses investigated that opposed the bill were certified B Corps, meaning that they have formally met requirements to include principles such as social responsibility and environmental sustainability in the documents that govern their business and have submitted to a certification process that includes annual reports on their progress in these areas (B Lab, 2017). In fact, most companies on the list of those opposed to the bill include language somewhere on their websites about their values and principles. That large companies feel the need to publicly display these commitments is a testament to the spread of CSR as an operating principle (Lindgreen and Swaen, 2010). The literature of business management has, for the last fifteen years or so, made a case for the business-sense of actions like these, though any direct effect is still difficult to prove (Beck-Olsen and Simmons, 2002, Lindgreen and Swaen, 2010; Lee, 2008). Proven or not, most large companies pursue some version of CSR activities as a matter of course. Research into CSR initiatives, and marketing more generally, by industry research and critical social scientists, has underlined the importance to consumers of authenticity in branding (Holt, 2002; Balmer and Greyser, 2006). CSR activities that fit a brand's image, are seen to be public serving, and are perceived as impactful are generally given more credit for being authentic (Alhouti, Johnson, and Holloway, 2016). While many industries implicated in this controversy aligned with political expectations (Hollywood and Silicon Valley are not expected to take even a neutral stand on the issue of LGBTQ rights), it is the broad range of industries acting in opposition that is notable in this case. That may be a function of the rise in support for LGBTQ rights in the last three decades, 
particularly among those who have benefitted most economically (Anderson and Fetner, 2008). Between the broad change in societal attitudes and the legal support for marriage equality, supporting LGBTQ rights is a fit for more brands than ever.

The companies that supported the bill, in contrast, are more likely to be retail businesses, such as lighting, trades, including carpenters and tile installers, or industrial manufacturers. These include a wood coatings developer, a bakery, a contractor, multiple lighting stores, a car wash, several packaging manufacturers, and a large real estate business that operates in several states. None of HB2's commercial supporters were B Corps. These results fit exactly with Anderson and Fetner's (2008) findings about global attitudes towards LGBTQ issues tracking closely to income levels. Those who spoke publicly in support of HB2 did so as individuals and business owners, not as members of particular industries (Fox46 Charlotte, 2016; Harfenist and Cohen, 2016, Peralta, 2016). The presence of a number of businesses and individuals that identified themselves directly with Christianity speaks to the salience of that identity in America generally, but particularly in the South.

\section{DATE IMPLICATED}

Most of the companies on the list signed onto their respective open letters very early in the controversy. There were waves of new signers-on, particularly on the side of the opposition, which were likely strategically released by the HRC in order to keep the issue in the news. The biggest waves on the side of the opposition are March $29^{\text {th }}$ and 30th, 2016, when the Human Rights Campaign released the first round of signatories to their open letter to the governor Pat McCrory (HRC Staff, 2016; HRC.org, n.d.). 
A few businesses, almost entirely opposed to the bill, reacted early and independent of a non-profit organiser, however. Those include Mystery Brewing, Ponysaurous Brewing, and the 36 craft brewers who joined their efforts to fundraise in support of the LGBTQ community. The ringleaders of the brewers' group reacted on social media within a few days of the bill's passage and by April 11 had begun a fundraiser online. Early reactors also include Ben and Jerry's, who by March $29^{\text {th }}$ had signed the HRC letter and published a long and detailed blog post about HB2 and the religious freedom bills passed in states such as Tennessee, Georgia, Kansas, and Virginia. PayPal tweeted in response the day the bill was passed (Paypal, 2016a) and followed up with a blog post announcing the cancellation of a planned operations centre days later (PayPal, 2016b). Lionsgate had announced that it was relocating filming of a new show on March $24^{\text {th }}$, just a day after the bill's passage. Other notable companies that were quick to respond include Dow Chemical and Ingersoll-Rand, both of which have social media accounts and pages of their websites dedicated to issues of policy (Kolevar, 2016; Ingersoll-Rand, 2016).

The bulk of the businesses that signed onto the Keep NC Safe Coalition's letter of support for HB2 (there are no supportive businesses publicly implicated that did not sign that letter) did so during the first few days after the bill's passage. The Benham Brothers, as part of a business that includes their real estate companies but is largely built around the brothers' activism around Christian causes, made statements on Twitter on the day of the bill's passage, published three blog posts about the controversy during the period studied and continued to be outspoken on the issue up to the repeal of the bill in April 2017 (Benham Brothers, 2016a, 2016b, 2016c).

One notable example of an early response came from Hanes Brands Inc. whose name appeared on the Keep NC Safe Coalition letter, announced March 29th. When Hanes Brand was immediately asked to comment, they responded quickly, but only so as to make it clear that are 
not on one side or the other in a meaningful way (Killian, 2016). They did not claim to oppose the bill but they stressed the robustness of their anti-discrimination protections. There is much concern in the literature around CSR efforts by companies being seen as cynical or manipulative and the resultant pressure to portray authenticity (Lindgreen and Swaen, 2010; Holt, 2002). Reacting early is one way to combat such accusations, or to disclaim any involvement if your brand does not actually want the kind of attention that comes with a specific controversy.

\section{PlATFORM FOR ANNOUNCEMENT}

The majority of businesses on this list announced their support or opposition through advocacy organisations, most notably the HRC and Equality NC letter and the Keep NC Safe Coalition letter. For most, that was the only action they took publicly. Others included the issue in their social media feeds, blogs, in press releases, and in interviews. Some took the issue farther and pursued concrete actions including cancelling events and business ventures in the state. Less than half of the companies that opposed HB2 included the controversy directly on their social media channels. The smaller numbers of posts that were directly on social media can be understood as partly stemming from the relative novelty of the practice and partly from the strategic use of a variety of publishing platforms.

The majority of companies examined, both those opposing and those supporting, made no references to the controversy in their social media feeds. Those in support mostly did not use social media at all, a disparity that will be examined later in this analysis. Of the opposing companies, twenty made their support part of their social media feeds, website content, or published responses in industry magazines. Those who included social media messaging about the controversy were much more likely to be either B Corporations_-Kickstarter, Patagonia, Ben and Jerry's, Redwoods Insurance Group, and New Belgium Brewing fall into this category_or they were explicitly and 
publicly aligned with progressive values—Mystery and Ponysaurus Brewing, and Self-Help Credit Union are in this category. A third category made up of very large companies-Pepsico, Dow Chemical, Hyatt, PayPal, Ingersoll-Rand, Deutsche Bank—made this controversy a public part of their social media presence. Their actions, along with similar companies not examined here, made up the bulk of the media attention surrounding the controversy, and were part of a suit filed, by Nike and Apple, among 66 others (Chmiellewski, 2016), in July against the state of North Carolina. Finally, local businesses, including Myriad Media, The Fresh Market, the North Carolina breweries, and Smiles by Payet, a dentist, made the controversy a plank in their digital presences.

Opponents of the bill that did not include their position on HB2 in their social media feeds include multinational companies such as Merck and IKEA, whose social media presences stay true to their core products of pharmaceuticals and furniture, and entertainment companies whose feeds were primarily concerned with upcoming shows and the actors that starred in them. Some of those companies, notably A+E and Lionsgate, with lukewarm support from Fox TV, participated in a boycott of the state, scrapping projects that were in their infancy and moving production to British Columbia while continuing production of series that were further along at the time the bill was passed (CBC News, 2016). Lionsgate's various Twitter channels have hundreds of thousands of followers, presumably of all kinds of political persuasions, but the news of their shift in locations was reported by news agencies, including the Charlotte Observer, rather than in public releases or social media statements. Live Nation, on the other hand, has a history of materially supporting LGBTQ efforts but kept their involvement—support for artists boycotting the state, announced by the CEO in the industry magazine Amplify — off of their social media channels, which revolve primarily around customer interactions and GIFs of concert performances. This suggests that while 
political messages are a fit for many companies, inclusion of political messages on companyowned social media is not always considered appropriate.

That said, it does not follow that content marketing and use of internet publishing platforms to pursue influence is entirely absent if companies are not directly addressing an issue on their Twitter feeds. Nearly every company that opposed HB2 signed a public letter attesting to their opposition for a reason. They may have hoped to gain public approval and earn media attention or to shield themselves from negative attention from political consumers and activists. Where companies varied was in whether and how they leveraged that opposition on their publishing channels. Companies are strategic in their use of platforms and they are aware that consumer-toconsumer conversations, facilitated by social media, shape much of their brand value, so they attempt to set the tone of those discussions through their actions (Mangold and Faulds, 2009). Furthermore, the audiences that companies are attempting to reach with their content use a variety of online media and can be relied upon to spread the word when a company behaves in a way that impresses them. While a brand whose consumers are primarily technologically savvy young people might prioritize Twitter for political content, the way that the brewing companies in the sample do, others, such as the High Point Market, may prefer industry magazines, press releases, or letters, which reach different audiences, including business partners, employees, and other brands. Still others may prefer to let their audience do the talking or may not know how to effectively leverage their position.

The relative novelty of social media and the slow adaptation of marketing departments to its norms and opportunities leaves the practice of content marketing in its infancy. A company like Cabot Creamery, a dairy company and B Corp with parallels to Ben and Jerry's but a less developed social media strategy, may simply not be leveraging political content to its potential. 
Companies may be cautiously introducing political content marketing by signing the HRC's letter, but not incorporating that position into their own publishing strategies. Stakeholders that are invested in the issue will be able to find the company's name on the open letter, while most of their customers are not introduced to a potentially polarizing topic. That may be the case for a company like Honest, which primarily makes high end products for babies and families. The company might have come under fire from advocates if they had not signed the HRC's letter, but their customer base is perhaps too mixed in its opinions of LGBT issues to justify the company becoming more deeply involved. Exactly how such decisions are made should be explored in future research.

\section{LOCATION}

Fourteen of the companies opposed to HB2 and examined in this project were located in North Carolina, though some, like Pepsico, Seventh Generation, and others had significant business interests within the state, even if they are headquartered elsewhere. In contrast, nearly every one of the 43 businesses examined that supported the bill was located in the state. Very few of those businesses have a social media presence of any kind. Those that were willing to make public statements did so almost exclusively through newspapers and local television stations. They were also overwhelmingly very small businesses. The exception to each of those rules was the Benham Brothers real estate firm, which is large, operational in multiple states, and well represented on social media. It also takes the position, in contrast to Governor McCrory's public statements but in keeping with many of the individuals that publicly commented on the bill, that what is at issue with HB2 is not only private business rights, but questions of right and wrong grounded in Christian morality. 


\section{SUMMARY}

Individuals and businesses implicated in this controversy, on either side, are mostly represented by policy organisations, including the Human Rights Coalition, Equality NC, the Keep NC Safe Coalition, the Civitas Institute, and other non-profits. The role of such organisations is understood to be tied to a particular group of political stakeholders (Gray, Bebbington, and Collision, 2006), and in keeping with a more discrete, less converged model of civic life, in which political organisations engage in political speech, commercial organisations engage in commercial speech, and social interactions are somewhat removed from both. The companies went beyond being represented by an organisation to take political advocacy into their own communication channels are at the heart of the questions that this thesis attempts to address.

\section{TYPOLOGY AND ANALYSIS}

While the broad survey of the companies involved in the controversy surrounding HB2 is consistent with what one would expect of CSR efforts in terms of size, industry, and location, the case is distinguished by the way that companies were demonstrative in their actions and speech, as well as the number of companies opposing the legislation. Starting from my general results, I examined the cases in detail to create the following typologies: in-state defensive branding, strategic distancing, out-of-state content generation (benefit corporations), multinational and industry-specific advocacy, boycotts and demonstrative actions, and Christian identity politics. The following section presents the particulars of those typologies and evaluates the ways in which political content was integrated into existing social media marketing strategies. 


\section{IN-STATE DEFENSIVE BRANDING}

The response of the High Point Market and its supporting institutions, the New Season Market and the International Market Centre was presented briefly in the last section. Their statements will be examined more closely here, alongside the actions of other in-state businesses, including a group of North Carolina breweries. A high-profile attendee of the High Point Market suggested in an interview with PBS that customers "buycott" their goods because they are not responsible for or aligned with the legislation passed by their political representatives (PBS News Hour, 2016, 1:17). While they use language borrowed from the literature of political consumption, their strategy bears the hallmarks of reaction or reparation marketing, which focuses on controlling the message around a certain brand in the wake of a damaging event. Similar patterns of communication are present in other local businesses, including dentists, grocery stores, and music programs. The case of the craft brewers will show a more sophisticated integration of marketing, products, and politics.

The High Point Market, a twice-annual furniture trade show that is the largest in the world, made its public statement early, on March $28^{\text {th }}$. It was subsequently picked up by industry publications such as Furniture Today and Home Accents Today. The market made several statements on their Twitter feed, where their comments were addressed to "High Point Market attendees" (High Point Market, 2016) and concerned Tweeters were directed to their original press release. The first paragraph of the High Point Market's press release refers to both real-life conversations and to social media interactions that indicated that customers planned to boycott the High Point Market, whose spring iteration was scheduled for mid-April, in protest of the passage of HB2. The statement goes on to explain, in order, that 1) the Market feels beholden to point out the economic damage to both the public and government leaders 2) to point out that the Market 
itself does not discriminate in the way that HB2 does 3) express appreciation for supporters in government that provide a significant portion of the Market's funding 4) explain the forecasted financial impact to their stakeholders - here defined as the market participants and those who owe their jobs to the market's continued success and finally, 5) note that the High Point Market is "the largest economic event in the State of North Carolina each year" (Boschini, 2016, para. 10).

A week later, the CEO of International Market Centre, the self-proclaimed largest property owner at the High Point Market (Maricich, 2016), wrote a letter to the editor of Furniture Today underlining his organisation's support for the LGBTQ community, attacking HB2, and pointedly asking that boycotters not punish the market and its exhibitors for the state's actions. He admitted to being "bewildered" (Maracich, 2016, para. 2) by House Bill 2 and hopeful for its repeal. He goes on to underline that International Market Centers, like the High Point Market itself, does not discriminate on the basis of gender or sexual orientation, and, in fact, champions diversity in all its forms. He then makes the case for customers to continue to patronise the High Point Market, stressing that the Market is important to industry and that the majority of its exhibitors are both small businesses and from out of state and so not legitimate targets of outrage over the bill.

The emphasis on diversity and inclusiveness as core values has an obvious purpose in these statements - to shield the market from becoming the target of boycott activities. Given how much press such activities were getting and how many companies were involved, the High Point Market and its affiliates certainly had reason to fear. These statements also served to distance the Market and its supporters from the government that passed the law. Finally, they appeal directly to elected officials to change the law on behalf of the market, its organisers, and its beneficiaries. Some of this reaction supports an understanding of economic actors as encouraging governments to behave in economically liberal ways. It also suggests that the gap between regional politics and national 
and international norms puts mid-sized companies in an awkward position. Whether the actions of the Market ultimately influenced North Carolina's efforts to repeal HB2, they show a relatively straightforward public relations approach to an event that impacted the reputation of the market and risked its future earnings.

The Market's three-part effort, with direct media, proxy speakers, and social media outreach, has much in common with reactive marketing, or marketing content created to address something that has tarnished a brand in the public eye (Groza, Pronschinske, and Walker, 2011; Vanhamme and Grobben, 2009). In this instance, even though the market itself had not done anything contentious, they have made an aggressive effort to address HB2 in order to limit the damage to their company. Reactive CSR messaging as a marketing strategy is not highly thought of in CSR literature because consumers tend to read it as self-serving, rather than authentic (Alhouti et al., 2016; Groza, Pronschinske, and Walker, 2011; Vanhamme and Grobben, 2009). Other North Carolina institutions that took a similar approach to public statements include Smiles by Payet, The Fresh Market, and Self-Help Credit Union. The High Point Market behaved as might be expected of a business - reaching out to its primary stakeholders (furnishing companies) in the communications where they are likely to congregate (industry publications). While the market has active social media channels, and nearly 30,000 followers, those channels are primarily used for highlighting designers and attendees of the market and were not heavily used in responding the HB2.

A coalition of North Carolina craft brewers, lead by Mystery Brewing and Ponysaurus Brewing, took a proactive, and arguably more sophisticated, approach to positioning themselves politically against the bill. Like the High Point Market, these brewers have little flexibility in terms of their location. Unlike the Market, these companies court consumers in a reflexive, rather than 
reactive way. They have built their businesses around being the smaller scale alternative to industrial sized beer brewers, with more personal connection to their customers and geographic communities (Murray and Kline, 2015; Reid, McLaughlin and Moore, 2014; Schnell, 2003). Their approach to addressing HB2 integrated advocacy seamlessly into the content that fills their social channels.

New Belgium Brewing Company, a certified B Corp with locations in Colorado and North Carolina, was first to contribute to the Twitter conversation, with a tweet on March $28^{\text {th }}$ attacking HB2 and reaffirming the company's support for the LGBTQ community. Their statement emphasized their intention to "continue to work with like-minded partners in North Carolina" and made a case that the "best" way to change society was to combat legislation "wherever it should arise" (New Belgium, 2016). The statement was distributed to their 250,000 followers as an image file alongside an image of a glass of beer branded with the New Belgium logo and a link to a story in the Charlotte Observer that explained the controversy. New Belgium is no stranger to CSR initiatives, along with their B Corp certification, their website highlights a comprehensive list of causes and organisations they support, including groups aimed directly at influencing policy (New Belgium, n.d.). Their Twitter feed is an even mix of announcements for community events and highlights of citizenship content such as being named Colorado's "most ethical manufacturer" (New Belgium, 2017). Basically, it is a steady stream of beer and "good works" related content that mirrors the preferences of their millennial audience, with the politics alongside dog photos and beer puns. When they spoke against HB2, they did so not as citizens of North Carolina, but on behalf of a wider group of likeminded businesses and citizens. 


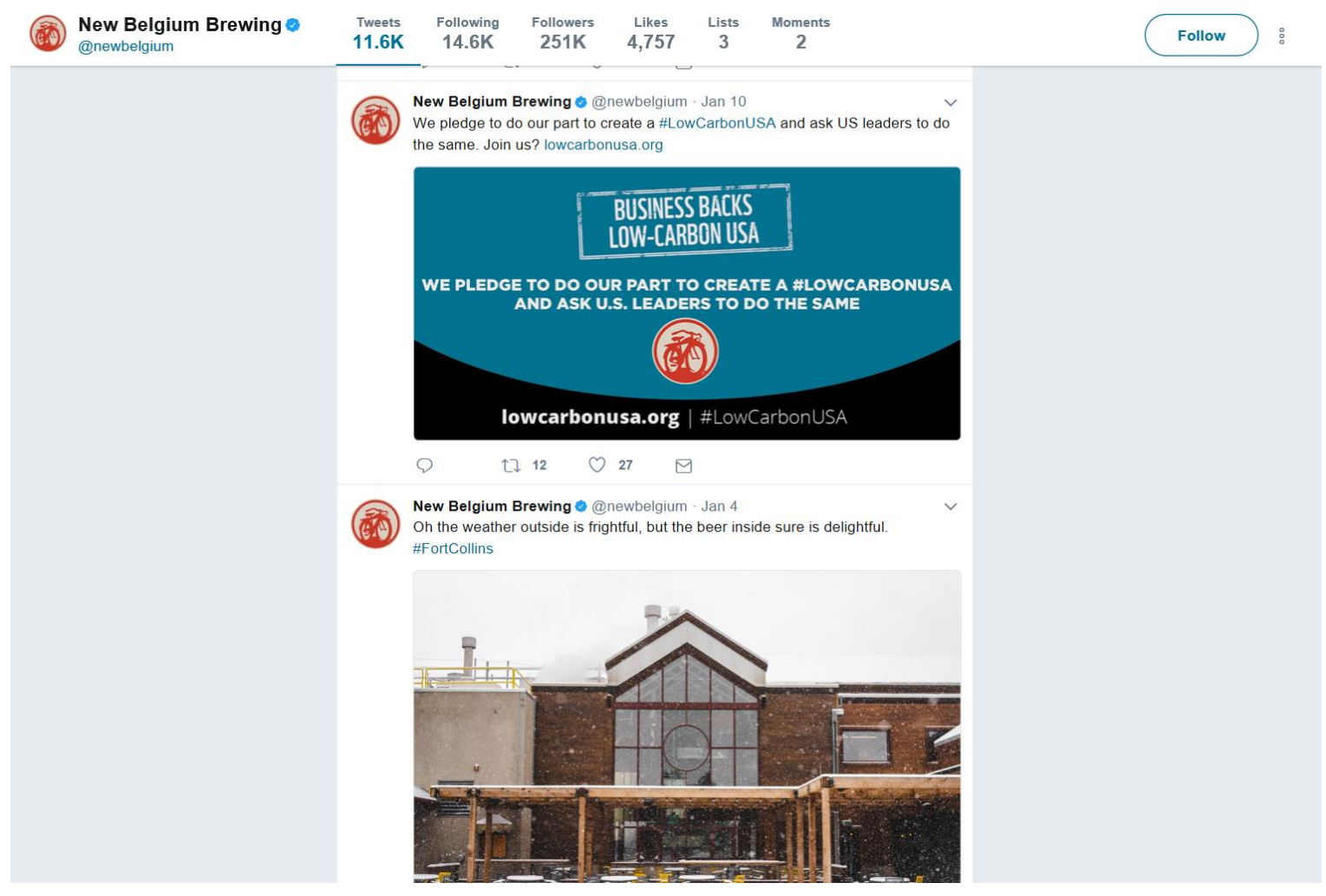

Figure 1: New Belgium Brewing Twitter Newsfeed

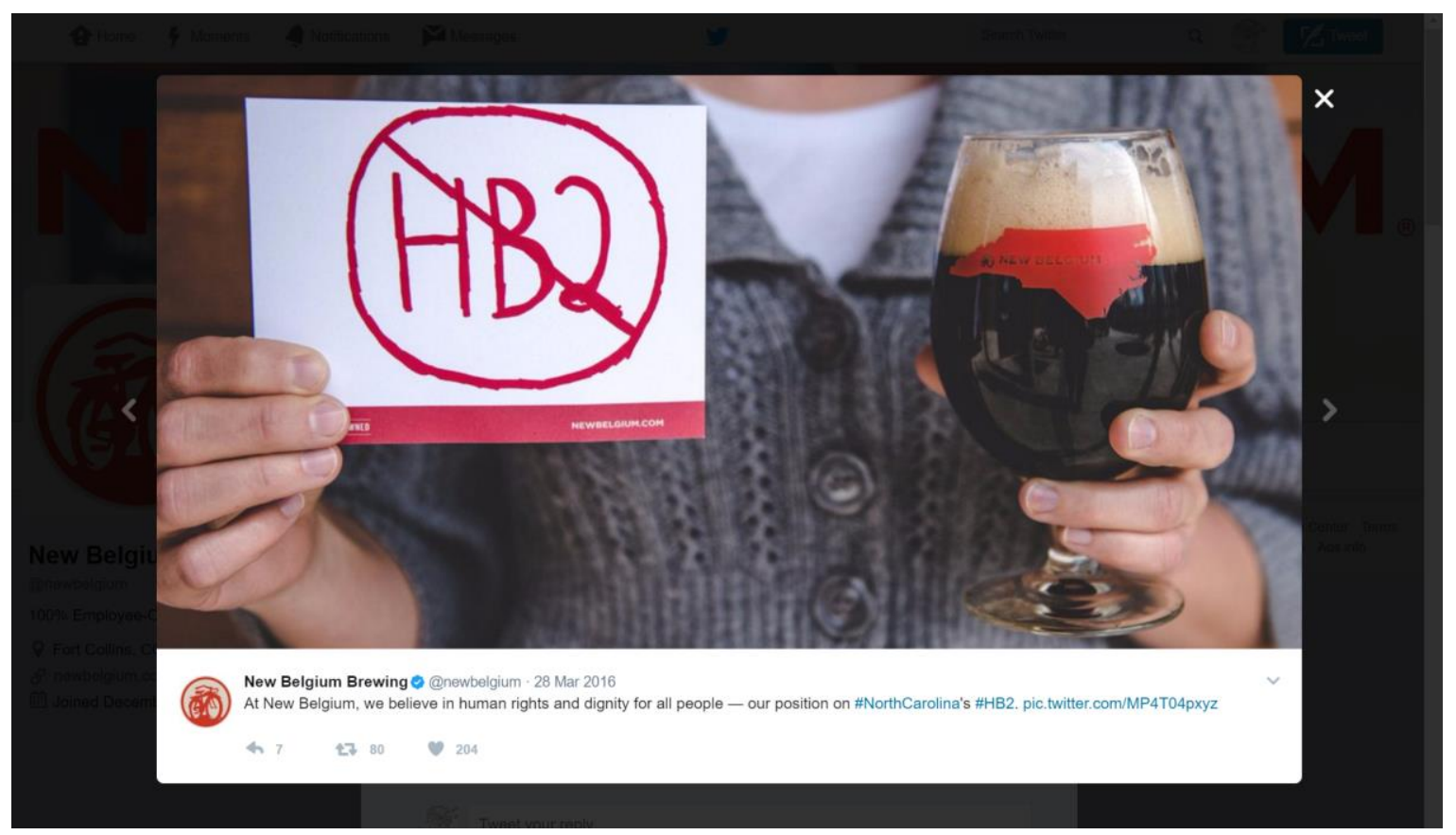

Figure 2: HB2 image posted by New Belgian Brewing 
Meanwhile, other North Carolina brewers had taken action that paired online outrage and offline business as usual. Led by Mystery and Ponysaurus Brewing, forty-three North Carolinian brewers collaborated on a fundraising operation based around a beer entitled Don't Be Mean to People: A Golden Rule Saison. While there were earlier social media reactions from many of the breweries on the list, the real attention rolled in when the group launched a crowdsourced funding campaign for the beer, with proceeds going to Equality NC and QORDS, an organisation that hosts summer camps for LGBTQ youth (Myers and Jansen, 2016). The fundraising was itself hosted on an affiliate of the crowdfunding site Indiegogo that is specifically dedicated to raising funds for social causes (Generosity by Indiegogo, n.d.).

The statement made by the leading brewers, Erik Lars Myers and Keil Jansen, takes a different tone and approach than that of the High Point Market, reflecting the different goals of the brewing companies and the culture in which they operate, but it serves at least one similar purpose as it distances the companies from their elected officials. The brewers begin by saying that HB2 made them angry, that they felt that the bill didn't "represent [them] as constituents, entrepreneurs, or business owners" (Myers and Jansen, 2016). Some of the wording is clearly a rebuttal to McCrory's claims about protecting the rights of private businesses, but there is also an implicit assumption embedded - I am not aware of any formal reason that the government of a state must represent the interests of every one of its entrepreneurs and business owners, save as a matter of political capital. HB2 itself does not impact what the businesses chose to do in terms of policy, so the leaders of the brewery fundraiser seem to be making an argument for the regulation of social issues around business or for a universality of regulation.

These breweries react to the controversy not (only) by petitioning their elected officials as citizens but by pursuing actions that are a natural extension of their existing marketing, creating a 
parallel between the business and the social action, one that can endear them to their customers and make a political statement at the same time. The brewers write, "What do two brewers talk about doing when faced with a world in which they want to make a change? They talk about making beer." (Myers and Jansen, 2016, para. 2 and 3). The statement is presented as a kind of logic, but there is no reason that the brewers could not have simply donated a portion of their proceeds to the causes they chose to champion, or made a statement of protest on behalf of their economically powerful industry. Instead, they chose a public extension of their ordinary business and branding activities that put them in line with a social sentiment almost definitely shared by their customers (research shows that craft beer aficionados are overwhelmingly college educated millennials, a demographic that is also more likely to be well-disposed towards issues of LGBTQ rights (Reid et al., 2014; Schnell, 2003)). The brewers offer products and content as perks to the supporters of their fundraising campaign. Along with the actual beer, shirt, and glass that their donations may have earned them, donors get updates and "special behind-the-scenes looks" (para. 13) into the process of brewing, including label design and canning day. Essentially, the brewers are offering the kind of engagement that marketers work to facilitate for brands on a day to day basis as prizes for a socially motivated action. The brewers' actions were also covered widely in the news, with industry outlets such as All About Beer Magazine and a plethora of beer-rating sites alongside media outlets such as the Huffington Post (who published the story on their "What's Working: Purpose and Profit" platform, sponsored by PWC, a multinational financial services company), NPR, Men's Journal, Indyweek, CBS North Carolina, among many others. The suggestion appears to be that while the government does not politically represent either the brewers or their customers, a product and its PR campaign can and does. There may or may not be an inherent problem with that approach in terms of results, but it certainly sidesteps any hint of 
traditional political or journalistic channels. At no point in this statement is there an appeal to traditional political channels, either in terms of the election that was to come in November or the elected political opposition.

The brewers present themselves as powerful representatives of moral interests at the same time as they play down their social position. On the one hand, they differentiate themselves from the municipalities, businesses, and "rock stars" (Myers and Jansen, 2016, para. 4) that seek to "punish" (para. 4) the state and cause harm to the communities within it because they have the luxury of leaving. On the other hand, they use the bully pulpit of their own economic prowess“a $\$ 1.2$ billion economic impact" (para. 7) — not to "condemn" but to "help" (para. 7). The organisations that the brewers chose to support_-Equality NC and QORDS — are already political non-profits that represent certain social interests. So, when Mystery and Ponysaurus say that want to benefit the organisations and "extend the opportunity to you to get in on the donations" (para. 12) they are actually placing themselves as middlemen between citizens and organisations to which those citizens could donate directly, if they so chose. The group effort of these breweries and their supporters likely ended up funneling more money to those organisations than otherwise would have been raised, either through their direct donations, including more than 40,000 raised by 1300 donors in the crowdfunding campaign, or the press that they earned. While there is a literature on cause-related marketing (Samu and Wymer, 2016), it tends to focus on advertising in a more limited sense than we see with the efforts of North Carolina's craft brewers, who have integrated their causes into their online channels in a seamless way that matches the lifestyle of their customers, allowing them to incorporate beer news and politics into the same channels that they are already engaged with. 
If political action is most fervent when it is on brand for certain actors than there are going to be limits to which issues are addressed or not addressed, and those issues will match topics businesses believe their customers will respond to in a positive way. As companies become publishers, with integrated political content geared to reflect the interests of their customer base, the idea of a public place where ideas are exchanged by private individuals retreats, as does the idea that political intermediaries might be a governable class of corporation separate from others. The selectivity of CSR efforts, particularly their emphasis on fit, undermines arguments for the efficacy of political consumerism as a general method of reaching political goals. Some might argue that brewers have only involved themselves with HB2 because their wealthy, educated customer base expects that kind of support. That may be true, though it is equally plausible that the owners of breweries and their customers resemble each other in their politics. It is both easy and safe for the breweries to react strongly towards this topic at this time, but that will not necessarily be true of other important political issues at other times. To better understand how a company's customer base might influence their political involvement, this discussion now turns to more reluctant players in the controversy.

\section{STRATEGic Distance}

When the NC Values Coalition released their list of businesses that supported the passage of HB2, it originally included the name of one Keith Zimmerman, signing as a representative of HanesBrands (Killian, 2016). Asked to comment, a HanesBrands spokesperson noted that a) Zimmerman was not authorised to speak for the company, b) HanesBrands had taken no position on HB2, and c) their company had strong anti-discrimination policies, that include gender identity and sexual orientation, which would continue to be enforced. HanesBrands is a significant employer in the Winston-Salem area in North Carolina but also a global brand associated with 
basic apparel—largely known for affordable t-shirts and boxer shorts. While their website touts their social responsibility in terms of environmental sourcing and working conditions, issues of identity, LGBTQ rights, and practically anything that might be considered controversial from a religious or socially conservative standpoint are not immediately evident, or evident even if one clicks deeper into their website looking for them. HanesBrands has received awards for their social responsibility efforts, which are aimed at the issues for which the apparel industry is most frequently attacked — working conditions and environmental harm. Hanes is happy to talk at length about some social efforts while they take a markedly less active role in others, like HB2. An expensive, environmentally themed ad campaign was announced in press releases, and additional press releases were released for events as diverse as donating clothing to victims of flooding in Louisiana, awards won for support of United Way, and recognition from corporate responsibility magazine (HanesBrands, Inc, 2016; HanesBrands,Inc, 2017). Hanesbrands, Inc, in short, appears to treat certain social and political issues as a fit for the brand, while others are kept at arm's length.

Hanes is a large, generic, affordable brand in the apparel industry. Their customer base, unlike that of the craft breweries or tech companies on the list, is quite likely to include people with varying opinions on HB2. From that perspective, there is less strategic payoff for HanesBrands to take a public position on HB2. The result is a public comment that attempts to take no sides, both agreeing that discrimination is wrong and declining to tell the legislature how to move react. There is something democratic, or at least populist, in this kind of stance, but troubling as well. If a company's stance on public issues is dictated by the price point of their product and they increasingly participate in content marketing, the difference between the content shown to people of different incomes will diverge at every level—media, advertising, and social. 
Thoroughly segmented content marketing has the potential to clear the public sphere of generally interested content.

HanesBrand's attempt to take a nuanced position resembles that of NASCAR in trying to draw a line around appropriate involvement. NASCAR chairman Brian France gave a careful answer nearly a month into the controversy when asked whether NASCAR would boycott over HB2 (NASCAR had signed the HRC's letter of opposition early in the controversy). France said that the business he heads opposes discrimination, that it was working against the law "behind the scenes" (Uttar, 2016, para.3), and that it was not a political organisation. His comments attempt to draw a line between appropriate involvement in the controversy and more visibly activist or "political" involvement, but as Papacharissi (2010) notes, a perfect separation between social and political activity is unrealistic. Certainly, such a separation is not practiced by either consumers or companies. Rather, "political life...adopts the practices and pace of social life" (p. 78) and social life, mediated by the tools of the new advertising industry (Turow, 2011), is saturated with the practices and pace of marketing and brand stewardship. Hanes and NASCAR walk a fine line in trying to avoid taking the "wrong" stance on HB2, i.e. one that would not be viewed favourably by their core demographics. Actors that are confident that their stance will be well received betray no such uncertainty and their reaction is more a matter of degree and strategy, particularly evident in the choice of whether to boycott or not boycott the state and whether to host or not host content on that choice on their own channels.

\section{Out-of-STATE CONTENT GENERATION (BENEFit CoRporations)}

Benefit Corporations, by incorporating the "general public benefit" (Johnson, 2013, p.287), into their operations, make an argument for an intermediate role between profit and public by dint of their existence. The high number of B Corps in the sample is not surprising, but their approaches 
to communications are instructive. To remain certified as a B Corporation, a company submit reports that compare their social and environmental performance to third party standards, along with details of actions the company took and rationale for why they did or did not achieve certain goals. (There is a distinction between being a benefit corporation and a Certified B Corp, but both designations require this kind of reporting.) Of the 54 companies analyzed in this thesis, ten were certified B Corps at the time of writing. Those companies were responsible for the most brandaligned reactions to the controversy, though a significant number of those businesses (roughly half) simply signed the Human Rights Campaign letter and no more. Ben and Jerry's issued an indepth blog post, complete with wordplay around their various ice cream flavours and rainbow coloured versions of their logos, to their 323,000 Twitter followers (Ben\&Jerry's, 2016). New Belgium Brewing posted a photo of a woman holding a glass of beer in one hand and a card on which HB2 had been written and then slashed through with red ink (New Belgium Brewing, 2016, see Figure 1, p. 54). Seventh Generation included an in-depth blog post in the "building communities" section of their blog, broadcasted to their 81,000 followers (Seventh Generation, 2016).

While B Corps make much of their reporting processes, there is considerable skepticism in corporate law over the concrete impacts of their legal enshrinement, not least because the certification is in its infancy. B Corps ostensibly exist to provide an extension of an oft-cited (but not necessarily accurate) mandate for businesses to maximize profits to include consideration of the public good. However, they do not actually provide stakeholders (as opposed to shareholders) the ability to claim a breach of duty if certain public considerations are not met. Rather than clarifying a relationship between companies and the public interest, they contribute to "the conceptual muddle" (Johnson, 2013, p. 292). Much of the expectation surrounding the form has 
been based on the expectation of financial recompense for virtuous behaviour, similar to efforts to prove that CSR is financially, as well as socially, desirable. It is too early to know whether such a market exists, but that has not stopped companies from aggressively branding themselves and their socially-directed activities. While benefit corporations were over-represented in the sample of companies (there are a little over 2000 B Corps in the US as of 2015), they were not more demonstrative than their fellow companies that opposed the legislation. Few of the companies that boycotted the state or cancelled projects there were B Corps, but B Corps were much more likely to include information about HB2 in their social media feeds. They represent 6 out of the 20 social media responses. In marketing, the importance of social media has fueled a practice of updating all channels regularly, often daily, which necessitates the production of large amounts of on-brand content (Roy, 2016; Hughes, 2016). For B Corps, on brand content must match both their products and their social missions.

One way to meet that expectation of content is to fill social media channels with social issues along with more traditional business marketing. Ben and Jerry's, considered a leader in social media marketing (O’Brien, 2016), wrote multiple tweets and an extensive blog post about HB2. Their social media feeds feature content daily that falls into the category of social justice, including tweets about Martin Luthor King, climate change legislation, the ACLU, and others all positioned directly alongside calls to participate in Free Cone Day and prank ice cream loving friends. The accounts of other B Corps in the controversy, including Seventh Generation, Patagonia, New Belgium Brewing, and Redwoods Group reveal similar patterns of social media use, though Redwoods group is considerably less active than those of the other two. 


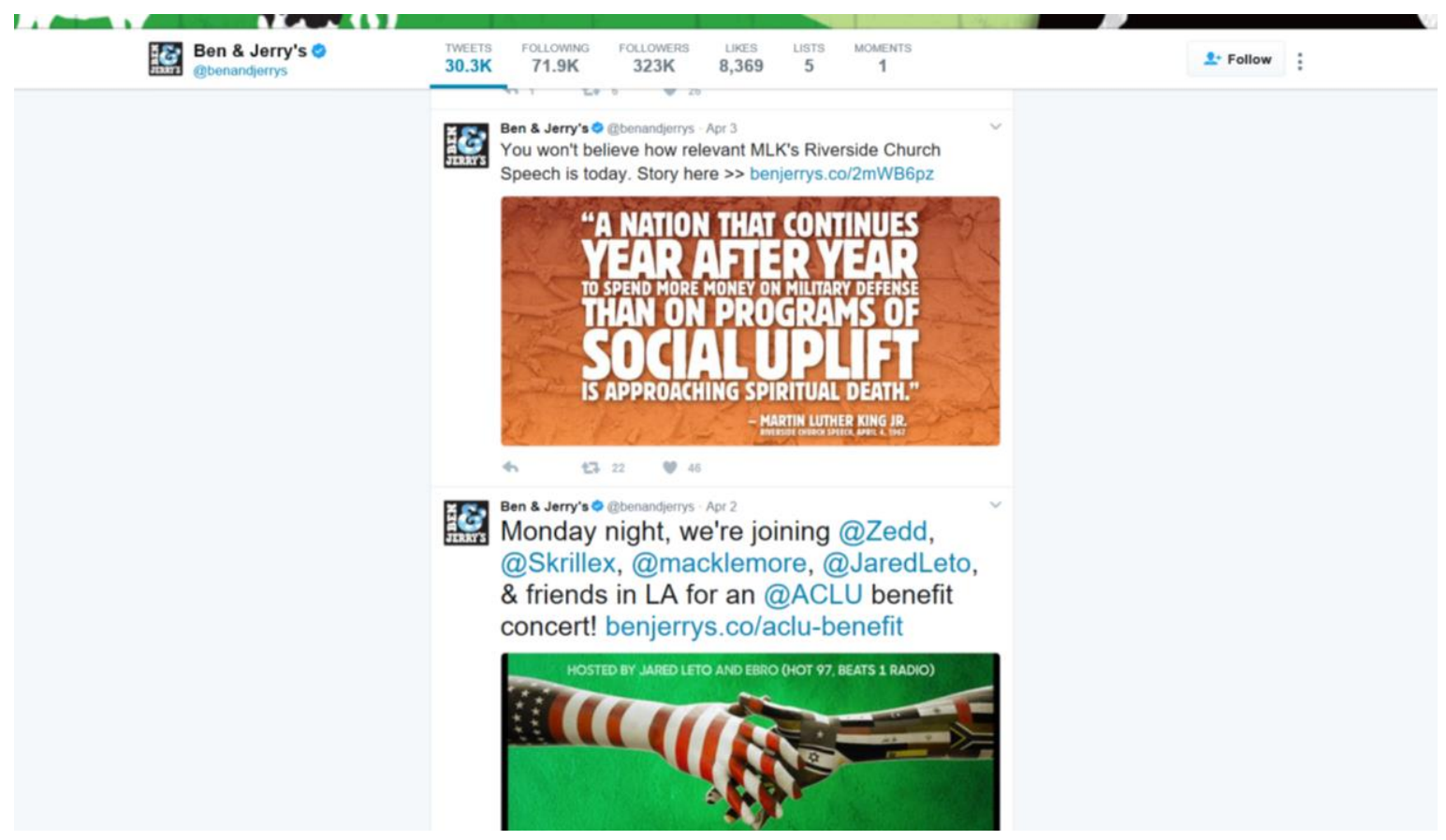

Figure 3: An excerpt of Ben \& Jerry's Twitter feed

In terms of impact, B Corps are preaching to the choir. Their statements were almost universally hailed with supportive responses, notably from employees. B Corps use the controversy to fuel their existing need for content that validates their branding, and few made a substantive shift in policy or plans (B Lab, a governing body, cancelled a conference). However, a significant proportion went beyond signing the letter of support to act as communication agents, publishing information of interest to people that opposed the bill. Their actions in some ways resemble the work of political intermediaries or interested constituents, but dovetail nicely with the principles of content marketing, which instruct marketers to be hungry for content that reinforces their brand with their target markets (Issacharoff and Ortiz, 1999; Holliman and Rowley, 2014). Only one of the B Corps listed has substantial ties to North Carolina, so their political statements tend to align with a universal conception of correct action, rather than one specific to a location. Social media statements made by B Corps do not appear to get more media coverage or 
social media engagement than those of other companies and are quite overshadowed by the responses to larger companies like Pepsi, Dow, and Ingersoll-Rand. The content appears less likely to change a public conversation than it is to reinforce and inform the perceptions of core customers.

\section{MultinAtionAl AND INDUSTRY-SPECIFIC ADVOCACY}

Unlike the B Corps that made up a large portion of the reaction to the HB2 controversy, larger companies that involved themselves did not necessarily claim to do so in the interest of the general public. Dow Chemical (49,600 followers) includes a short statement on the rationale for the issues that they advocate. On their policy website, they state, "Dow is actively engaged in policy areas that are critical to the competitiveness of chemical manufacturers and an innovation company doing business globally." (Dow.com, n.d.). On that site, a visitor finds recommendations on everything from tax regulation to education and transportation infrastructure, each presented as it aligns with Dow Chemical and its preferences. Dow Chemical's policy page does not mention LGBTQ rights or social equality, that information is on their culture and beliefs page. Antidiscrimination is not treated as a policy priority but as an issue of company operations, an approach echoed by any number of the companies that opposed the bill and potentially explaining why such a broad group of businesses were quick to involve themselves. Dow's Twitter responses are relatively strongly worded, first stating on their policy channel (1081 followers, with more than 300 retweets and likes) that the company opposes the North Carolina general assembly during deliberation on HB2 on March $23^{\text {rd }}$ and following that tweet the next day with an expression of disappointment in the signing of the bill (Kolevar, 2016a; Kolevar, 2016b). On the main, much larger, Dow Chemical Twitter account, the company shared articles about how companies, including Dow, were combatting religious freedom bills generally, though those tweets received less engagement than those that specifically mentioned HB2. The CEO of Dow Chemical, Andrew 
Liveris, has written a book weighing in on policy adjustments that Dow would prefer to see in the US.

Andrew Liveris is not the only CEO taking a personal stake in public policy outcomes. The CEOs of both Pepsi Co (315,000 on their news and innovation channel, more than 3 million on their main channel, 26,800 for CEO Indra Nooyi) and Hyatt (63,000 followers) are notable in list for taking actions that were credited separately from the actions of their organisations. In the case of Hyatt CEO Mark Hoplazmian, the company tweeted support for his signing the Human Rights Campaign letter and tagged that post with \#inahyattworld, a hashtag associated with an ongoing advertising campaign begun in 2013 that envisions a utopian future in terms of its alignment with Hyatt (Hyatt, 2016; Hyatt, 2013). That tweet attracted little in the way of attention with just 10 retweets and 25 likes. The CEO of Pepsi Co, Indra Nooyi, meanwhile, tweeted a photo from her own account of an open letter that she had hand-delivered to the governor of North Carolina (Nooyi, 2016). Her tweet attracted 567 retweets and 730 likes, as well as more than a hundred replies, as respondents sent Indra Nooyi comments approving and condemning her actions, while arguing with their fellow commenters. The CEO of Etsy, in keeping with the DIY ethos of his company, published a response to HB2 on Medium, a self-publishing startup. His response referenced his upbringing in North Carolina, and argued against boycotting the state.

If we go by the literature of CSR and content marketing, the difference between Hyatt CEO's tweet and the Pepsico CEO's letter is obvious - one appears self-serving, the other community focused. The Dow Chemical CEO is actively involved in the company's policy efforts, though the response to HB2 was made on a brand channel reserved for policy issues. While there is a small amount of scholarly literature, and marginally more in business press, on the role of CEO's in providing value to a firm it is possible to include it in the trend toward marketing content 
rather than advertising (Park \& Berger, 2004). If a CEO's actions can dovetail with a social message and come across as authentic and impactful, then the company is likely to consider that premium content — "providing value" as Marriot International's VP of global and creative content marketing said in an interview with Advertising Age (Neisser, 2017). The value is perhaps enhanced in terms of perceptions of authenticity by being created by a human seen as running the company, but it serves essentially the same purpose as other political content marketing efforts.

\section{BoycotTS AND DEMONSTRATIVE ACTIONS}

The biggest news story surrounding the HB2 controversy was not necessarily the potential for discrimination against LGBTQ individuals, but the economic impact that seemed likely to result from the passage of the bill. Boycotts and cancelled projects led Forbes to forecast losses to the state totalling as much as $\$ 630$ million (Jurney, 2016). Businesses that either did boycott or publicly supported such actions in my sample included PayPal, Deutsche Bank, A+E, Lionsgate, Seventh Generation, Google Ventures, and Live Nation. Most of those businesses were not based in the state, though Seventh Generation has a ventures office in North Carolina, and were large, public, multinational companies. They were equally likely to announce their boycott activities directly on social media or omit it from their regular feed. For the most part, these companies announced their intention to boycott the state on their own website, in blog posts directed at their supporters, or in newspapers, after internal directives had been leaked and they were asked to comment. Both approaches resulted in attention from national, international, and regional press.

Every business that threatened or enacted a boycott was a business large enough to have a marketing department working to consistently generate content about the brand for their own channels. None of them were located inside the state of North Carolina and most were technology and entertainment companies, industries that tend to be politically progressive. All of them were 
active across the U.S., at least, and beholden to a large customer base. Most companies, particularly Deutsche Bank, PayPal, and Live Nation, made statements to the effect that their decision to boycott the state or cancel a project was an extension of existing institutional commitments to diversity and their employees (Frankfurt am Main, 2016; Schulman, 2016; Brooks, 2016). While the companies are reacting to a situation created by the North Carolinian legislature, their actions precede pressure from advocates - calls that are easy to foresee in light of the prevalence of the political consumption, and in particular the way that social media has enabled "pile-on" approaches to activism directed at corporations, particularly around LGBTQ rights (Becker \& Copeland, 2016; Burgess and Matomores-Fernandez, 2016). Rather than playing defense against an activist public, these companies can move ahead of the topic, earn credibility and "value in use" (Rowley, 2008 in Holliman and Rowley, 2014, p.275) for their core audience. The alternative is spending time and money bargaining with and defending corporate choices to stakeholder groups - an anathema in a stakeholder-focused, risk-averse industry aware of consumers' abilities to co-create value (Gregory, 2007; Vallaster \& von Wallpach, 2013). By being proactive, they fuel expectations that the role of corporations is to support the public good-not as taxpayers, but as investors.

Some companies took a strong action toward the controversy—boycotting or making public statements, but did not include those actions on their social media feeds or websites. Notable among these were entertainment companies such as Lionsgate, A+E, and Fox TV. While these companies took varying degrees of action—Lionsgate pulled a production from North Carolina, as did A+E (Campbell, 2016) - they did not share those actions on their social media platforms. Instead, their statements were made to their employees and then reported in traditional media outlets. The entertainment companies that boycotted North Carolina update their Twitter, 
Instagram, and Facebook profiles multiple times daily. Photos of celebrities, clips of upcoming shows, and content shared by fans about stars and shows make up nearly one hundred percent of the content shared on these feeds, presumably because that is the kind of content that is "valuable" and "helpful" to entertainment audiences. Their political actions are, then, presumably aimed at a different set of stakeholders, their employees most of all, since the firms do not seem to be courting wider public interaction—not issuing press releases, for instance, even though the newspapers did report their decisions. With ready-made streams of brand-aligned content, there is not much reason for a movie studio to turn a controversy into content.

\section{Christian Identity Politics}

While very few of the companies that supported HB2 were publicly vocal about that support outside of signing the Keep NC Safe Coalition letter, a number of the individuals who signed were interviewed in the media and made statements to the effect that allowing biologically male individuals into women's washrooms violated standards of decency. Mike Wolff, of KC Solutions, for instance, was quoted as saying, "There are rights and wrongs in this world. And this is something that has to be addressed from a different perspective [than business]" (Fox46 Charlotte, 2016). Others quoted to similar effect include Greg Humphrey, of Heaven's Best Carpet Cleaning (WBTV, 2016). Judy Hale, of Lighthouse Electric, Bill Huffstetler, of Collision Centre of Stanley County, and Cheryl Jones, of ICI Lamp Company couched their support for the bill in terms of the privacy and security of women and children (Peralta, 2016; Harfenist and Cohen, 2016). The governor of North Carolina made a point in his public statements of distancing HB2 from religious freedom legislation. However, the social media platforms, particularly LinkedIn, of individuals and businesses supportive of the bill unsurprisingly reveals a significant amount of religious affiliation. The distance between the face that the NC government tried to put on their 
bill compared to the motivations of supporters of the bill reveal is not the question of this research, however. ${ }^{2}$ Very few of the businesses that were part of the NC Values Coalition letter made either their religious identity or their support of HB2 part of a social media feed because very few of those companies had active social media feeds. There is one notable exception.

The Benham brothers are twins, originally from Texas, who played professional baseball before starting a real estate company. Their real estate business was successful and lead to opportunities for a television show about property development. However, the brothers' outspoken opposition to LGBTQ rights and comments about LGBTQ individuals, particularly words spoken at a Washington, D.C. prayer rally, scuttled plans for the show (France, 2014). In the aftermath of that controversy, the brothers embraced a role as publicly unbending Christians. They have coauthored two books. Whatever the Cost (2015) directly addresses their faith and its repercussions on their public life and Living Among Lions (2016) is a more general set of life advice for Christians in an unfriendly political and social climate. The Benham Brothers commented more frequently, more consistently, and more emphatically on HB2 than any other business, for or against the bill.

The Benham Brothers began tweeting the day the bill was passed and consistently did so throughout the time examined. They also made many posts to Instagram and Facebook, wrote at least three in-depth blog posts for their website (Benham Brothers, 2016a, 2016b, 2016c), appeared at public rallies (Peralta, 2016) and on media outlets, including ESPN (2016) and Fox Business (2016). Those appearances are catalogued on their website, which draws attention to the brother's Christian works, including fundraising through private business for missionary work, along with

\footnotetext{
${ }^{2}$ Former governor Pat McCrory has firmly corrected interviewers that compared HB2 to religious freedom bills passed in Georgia, Indiana, and Mississippi (McCrory, 2016c). He insisted the bill was a matter of privacy, rather than religious conviction. Supporters of the bill, by contrast, thanked the governor for protecting religious freedoms and Christian values (Benham Brothers, 2016a; Harfenist and Cohen, 2016).
} 
activist involvement against abortions (benhambrothers.com). Arguably, the controversy presented an opportunity for the brothers to draw attention to themselves and their businesses through their very public performance of support. There is little need for them to invest in costly data-intensive advertising aimed at targeting their likely demographic when outspoken positions that support the products that they sell brings them plenty of media attention. In some ways, their involvement is more similar to their ideological opponents such as Seventh Generation than it is to a more neutral brand like Hanes. Both conservatives and progressives have established themselves as hubs for a political position-showing "thought leadership" in the parlance of content marketing (Holliman and Rowley, 2014, p. 286) — and retaining that position requires that they upkeep their channel. By consistently and passionately engaging with HB2, the Benham Brothers have a ready source of content as well as an opportunity to demonstrate their bona fides in reaction to an unfolding situation.

\section{Brand-ALigned CONTENT AND THE PUblic SPHERE}

Companies enjoyed a privileged position in society, as markers of status and makers of taste. The rise of social media as an important site of marketing, with an accompanying demand for ceaseless updates of high-quality content. Certain companies used the controversy around HB2 as an opportunity to connect with their consumers and engage with their social media followers. The impetus towards more and higher quality content, targeted directly at a customer base closely aligned with the brand, makes the inclusion of political content a relatively easy decision for marketers, but also increasingly makes them a direct target of political action — a lever against behaviour that may not be directly regulated but can be controlled through the removal of funding (O’Reilly, 2017; Grynbaum \& Mahaswari, 2017). The next chapter will highlight instructive examples of this behaviour-less political consumption than direct lobbying of and by for-profit 
companies - and consider the directions these actions may take as formerly separate spheres of action increasingly converge. 


\section{CHAPTER 3: CONCLUSION}

Research on the convergence between commercial and political behaviours is particularly significant when voter turn out is decreasing in industrial democracies. Political consumption and interaction with brands have only become more common and political communication continues to be a winning PR strategy for many companies. The combination can make traditional political channels appear slow or altogether unresponsive. The development of marketing strategies responsive in the ways that I have outlined in this case study may present an untapped resource for political representation. However, the kinds of actions, kinds of speech, and legislator's response to this controversy varied wildly. It is hard to assess the potential of corporate communications to aid social justice causes in the long term, though groups are embracing wholeheartedly tactics to communicate with and pressure brands. Brands, for their part, repeatedly demonstrate their willingness to move, in ways large and small, in reaction to public pressure, or the anticipation of it.

The willingness of companies to respond to political activism has given rise to a constellation of advocacy organisations that target companies or their consumers. For example, Second Vote, a self-described "conservative watchdog for corporate activism", informs shoppers about progressive political causes supported and funded by businesses and encourages consumers to avoid purchasing goods from those companies ( $2^{\text {nd }}$ Vote, n.d.). On the left, along with longstanding practitioners of campaigns targeting corporations, such as Greenpeace, campaigns launched in the last few years are targeting companies linked to politicians, companies that advertise on controversial shows and websites, as well as directly addressing company mergers, lawsuits, and donations. In the aftermath of Donald Trump's election, there has been a notable uptick in groups applying those tactics, including Sleeping Giants, a progressive social media 
organisation that encourages people to tell companies when their advertising appears next to objectionable content, and Grab Your Wallet, which asks consumers to boycott a list of businesses tied to the Trump family (Hao, 2017; \#grabyourwallet, n.d.). In short, businesses and their operations are prominent targets for activists in a variety of contexts. While there is no legal principle to prevent companies from working with whom they wish and advertising where they like, their customers tend to care less about the letter of the law and more about whether the actions of brands are compatible with their own identities. There is some anecdotal evidence that commercial responsiveness to this kind of pressure is accelerating. Color of Change, an advocacy group for racial justice, has made targeting companies, as advertisers and donors, a core plank of their technologically driven strategy (colorofchange.org). When the group pressured advertisers to leave Glenn Beck's controversial right-wing show in 2009, it was over two years before there were results. In comparison, a similar campaign against The O'Reilly Factor in 2017 lasted two and a half weeks, with advertisers beginning to pull out almost immediately upon being targeted (Grynbaum \& Mahaswari, 2017). Large scale group targeting, facilitated by social media, of businesses, as tacit supporters and enablers of political regimes, appears to be getting results.

In this thesis, I have argued that the same convergence of technology, space, and practices (Papacharissi, 2010; Turner, Michelletti and Stolle, 2008) that blurs the lines between consumers and citizens acts upon the businesses that market to them, making all businesses with an online presence publishers to a greater or lesser degree. The blurring between companies' roles as producers of products, and even as avatars of lifestyles, and communicators in a more general sense is seen in the ways that businesses involved in the HB2 controversy claim to represent competing groups, interests, and roles while undercutting the legitimacy of traditional political actors - including elected representatives. Rather than claiming to act on behalf of citizens who 
have elected them, these actors claim to act on behalf of one or many groups or reasons, including universal rights or morals and their employees and stakeholders. These claims introduce a strange orientation to marketing communications, turning them towards a social mission without losing sight of the bottom line. We can expect similar instances of corporate political communication, though not frequently at the same scale, going forward. Pressuring companies to act has become more popular with advocacy groups and has provoked significant reactions from companies that have been targeted. There is no reason, on the surface, not to harness the economic sphere as a place to rationalize social relations, but commercial communications are fundamentally different than, for instance, journalism, in the ways that they are produced and disseminated and the ways that they are held accountable.

This consideration of commercial-political communications in the HB2 controversy has examined behaviours that may align with Arvidsson's (2008) concept of the social construction of value in exactly the transformative way he describes it, with communications motivating companies to create social value through political action. There is also evidence to support Couldry and Turow's (2014) prediction of a society segmented by communications technology, no longer receiving the same messages as their peers from the media, politicians, and even marketers. While this thesis has focused on the content produced by powerful companies, this section will attempt to evaluate the pros and cons of this development from the perspective of the citizen-consumers that they purport to serve. To appraise whether these approaches facilitate public communication that is more representative, objective, and able to rationalize power relations, I will be referring back to scholars of the public sphere introduced in the literature review-Habermas, Trenz, and Papacharissi. The section will conclude by identifying questions this study was not able to address 
about the scale of corporate political communications, their reception by different audiences, and historical parallels to corporate dominance online.

\section{ARVIDSSON AND THE POTENTIAL FOR AN ECONOMIC SPHERE}

The targeting of businesses on grounds of social justice might appear to be a practical example of Arvidsson's theories about the social construction of value, but the theory's relationship to electoral politics, political geography, and public communication is unclear. Even those inclined agree that the backlash to HB2 was a kind of social construction of value would have to admit that the offending legislation was replaced with a bill that addresses very few of the fundamental concerns of those that protested. Using businesses as a conduit for political ideas runs the risk of excluding the public in the broadest sense and of segmenting communications with the public in ways detrimental to the exchange of ideas. When businesses reacted to the bill's passage it was done in a way that shored up their relationship with their base, not in a way that recruited new customers, unless they held sympathetic political views. At the same time, North Carolina, a state that has been in conflict with the law for gerrymandering electoral districts and attempting to strip the powers of political opponents, adjusted its position on an unpopular bill in the face of public opposition (Newkirk II, 2017; Omar, 2016). Arvidsson's social construction of value envisions a central role for digital technology and social media in the management of companies' reputations and, by extension, their financial value. He does not extend his predictions to companies impacting legislation as directly as asking, or extorting, legislative outcomes. Regardless, his central predictions seem to hold true in the case of HB2. For-profit enterprises, urged on by their core customers, chose to build their reputations through the pursuit of socially just policies, earning media and public standing in the process. 
The reaction to $\mathrm{HB} 2$ is arguably a practical example of brands providing a wider deliberation on recently passed legislation while using media platforms to strengthen affective brand relationships with communities. Issacharoff and Ortiz (1999), in an article on political intermediaries, entertain the idea that corporations might be credible agents of the views of large groups of people. For Arvidsson, an "ethical economy" would constitute a wider form of deliberation, potentially transforming capitalism as marketers invest heavily in retaining the trust of key communities. Companies considering the concerns of key stakeholders and bringing those concerns to the North Carolinian legislature could well constitute an efficient form of public consultation. While Arvidsson is vague about the kinds of "things" that can happen as a result of "mobilizing...social capital" (2009, p. 23) it seems evident that one of those things might be brands deciding en masse that a state's legislation is not contributing to their economic commons.

The shift to harnessing companies' political power by demanding action, rather than fighting corporate influence, is something of a departure for progressive activists. While most progressive activists continue to have a low opinion of corporate money in politics, there is a certain amount of strategic resignation toward what brand positions can do for public opinion and legislation. More recent organized protest has taken direct aim at corporate mergers and lawsuits to influence outcomes. Sum of Us, for example, has an explicit mission to curb the power of multinational corporations through a variety of tactics, including negative publicity. Their activities include petitions and even funding lawsuits, such as litigation against Bayer (incidentally a signer of the HRC letter opposing HB2) for a pesticide that may be harming bee populations (Sumofus.org, n.d.). The understanding appears to be that activists must engage directly with brands to influence issues important to society. While companies have long been accused of having a damaging effect on democratic societies, notably by public intellectuals such as Naomi Klein, 
efforts to curb their influence have produced little in the way of results, and Citizens United has come to symbolize a major defeat for those opposed to high levels of commercial influence in American democracy (though its actual impact is much more nuanced) (Bai, 2016). However, companies consistently respond to complaints from key communities, which presents an opportunity to curb undesirable outcomes.

Couldry, Turow, and Segmentation through Personalization

As a demonstration of the political power of consumer communities, commercial action may be a relatively limited tool. It may have been a useful means of protesting an issue of discrimination against LGBTQ people in the continental United States, but there are important political issues that are unlikely to attract the attention of enough marketing teams to make corporate pressure effective the way it was in the case of HB2. Marketing does not stray far from "feel-good" campaigns and political issues frequently feel far from good. For instance, when Texas passed legislation that limited access to abortion services, there was no coalition of companies boycotting the state (Gambino, 2015). Even though women are an important consumer category, the issue of access to women's healthcare is both contentious and hard to frame in positive, empowering terms, and so the issue does not attract a large enough group of companies, at least, not those in favor of access to abortion services, to pressure lawmakers. Commercial involvement with abortion rights tends to come from pro-life groups targeting companies that fund Planned Parenthood (2ndVote, n.d.; Berry, 2016) and issues of women's access to abortion services are generally upheld by the courts (Gambino, 2015). The risk of treating commercial support for legal rights as a measure of their correctness is turning political protections into a popularity contest and short-circuiting legal processes. Activists might pour resources into pressuring companies because they feel that they need commercial support to prove social support for an issue rather than using 
legal and institutional means. When marketers gain powerful political platforms, and even if citizens increasingly turn to them as sources and targets of political speech, considerations of brand safety and content control will continue to take priority over normative questions of the public good. Moreover, corporate reaction will continue to depend on consumers with the knowledge and numbers to make their preferences as stakeholders known. While Arvidsson is right to predict that companies' consideration for their reputation leads to social actions, a more likely outcome than transformations in capitalism is further division of public communication.

The reaction to HB2 could well be evidence of Couldry and Turow's (2014) darkest predictions - realities differently constructed based on the efforts of marketers to segment and target consumers. Consumers following the various companies involved were not treated to a nuanced evaluation of the effects of HB2, but a partisan invective coloured by extreme scenariosnothing new for political content but something of a departure for marketing. These communications privilege affect over empiricism. Democracy hinges on credible consultations between legislators and society based on common facts, themes, and references. Couldry and Turow doubt the possibility of maintaining a common agenda in the face of "advertisers and marketers [who] pursue business goals that require...the optimal personalization of content to fit the features that mark off one consumer from another" (p. 1711, italics present in the original). Personalization facilitates the fragmentation in the public sphere, allowing or encouraging people to interact only with media that feels comfortable to them. Content marketing fits squarely into patterns of personalizing the marketplace and maximizing consumer comfort.

Couldry and Turow's analysis moves from considering the personalizing of production of content and audience self-selection to the way data enables certain kinds of content to be directed to certain kinds of consumers. In passing, they mention the large budgets devoted to evaluating 
the success of content and ads served. Dedicated budgets for evaluation, rather than pre-emptive, data-driven targeting of content, allow companies to know what has been successful and therefore what is likely to be successful. Constant appraisal of content performance removes much uncertainty around incorporating political themes and issues. Rather than an insidious use of big data, a trial and error approach to content production still results in radically different content being shared to different groups of people. I do not expect that the breweries in North Carolina use more than cursory levels of data-targeting, but I would be surprised if many of their followers are exposed to political content that conflicts with their own perspectives with any regularity. Marketers already know who they are talking to and how the content is likely to be received. If there is a case to be made for companies passing along consumer opinions to elected representatives, there is not one for company channels facilitating dialogue between citizens of different political opinions.

Couldry and Turow consider that audience trust in publishers such as newspapers might be undermined by consumer awareness of targeted content, leading to consumer revolt. But content created by marketers themselves is another matter-consumers have complex relationships with brands, for instance, that can include trust and loyalty (Hess and Story, 2005). Company content may not be seen as biased or compromised in the same way that publishers' content may be, even when it is clearly a vehicle for a brand. That is more likely when content is not framed as a sales pitch for a product but as general content from a brand, especially one that has a public personality and identifiable employees, something that is a sticking point for social media influencers (Shtern, et al., 2017). Widespread content marketing may well undercut publishers with different standards for production and thus some of the "regimes of justification" (Boltanski \& Thevenot, 2006 in Couldry and Turow, 2014) deemed essential to the sustainability of a complex society. At its 
extreme, "we will inhabit an information landscape of constant updates on the issues that are closest to us, regular but trivial distractions interrupted from time to time by grand news spectacle, and occasional exotic curiosities." (p.1722). Brands in the newsfeed become part of the noise about the issues closest to their consumers, contributing to the limitations on accessing other news and perspectives. Couldry and Turow are right to be concerned, but political consumerism is now embedded in public life, and brands have found it in their interest to cultivate consumers' taste for it.

\section{Limits ON THE Potential FOR COMMERCial Political SPEeCh}

Courting social influence online involves marketing practices that are opaque and unaccountable to most citizens. When those marketing practices include political issues, it raises questions about the impact on the public interest. Political messaging will continue to be incorporated into brand messaging while the practices of content marketing will likely maintain its momentum. If the practice becomes as widespread as seems likely, there is potential for negative effects on political institutions of consultation and on the publishers that continue to be an important conduit for citizens' understandings of one another.

Companies are unlikely to be capable of delivering broad societal changes of the kind that have transformed society by protecting vulnerable populations and the environment through legislation. There is no such thing as a New Deal for commercial practice. But the service logic that pervades the commercial space means that companies will try to respond to what is important to their customers, making themselves targets for politically charged practices. Companies portraying themselves as a one-stop shop for their customers' lifestyle and political identities and ambitions risks distracting from - and by extension, atrophying — the political systems responsible for widespread legal protections, distancing constituents from the political representatives meant 
to serve them. Service logic as a conduit for political speech also raises concerns about who is identified as a stakeholder. In commercial management, stakeholders are defined by their levels of interest and power. Citizens are guaranteed political representation by right, customers are not. There is a risk of mis-identifying who is meant to, and who is able to, substantively respond to questions of government policy and political and social priorities. However, it is difficult to imagine how one would govern commercial communication that is political and how to justify doing so. Political speech by corporations has been protected again and again in the US and abroad. Companies and their behaviours routinely fall under the broad umbrella of civic engagement and efforts to address concerning trends tend to put responsibility on the consumers of speech, rather than the speakers, i.e. through teaching critical thinking and media literacy. The critical abilities of consumers are going to be tested by the multiplication of speakers online and the invisible hierarchies behind their speech.

Political pressure brought, in large part, by companies appears to have been effective in forcing the repeal of HB2 in North Carolina. It is not clear whether that effectiveness can be generalized to non-U.S. contexts, given that country's extreme social policies and permissive corporate law. While the businesses that were involved with HB2 were not limited to the U.S, and political consumption is widespread in other parts of the world, companies do not often react the way they did to HB2. In countries with more extreme social policies, companies - sometimes the same companies that were outspoken elsewhere - are often mute. PayPal, for instance, has locations in countries such as Saudi Arabia and India, where LGBTQ rights are more directly infringed - a fact that was consistently pointed out by supporters of HB2, who derided corporate actions as hypocritical virtue signaling. There may not be the same PR benefit to taking political action in countries where the legislation is either less polarizing or where the intended audience 
feels less strongly about an issue. Without a population that is sensitive to the issues, there is no payoff for companies making a political stand, and participation will be limited. Much of the political actions taken are done for the benefit of western audiences, who may have little time for the politics of far away countries. Likewise, issues that enjoy less widespread support than LGBTQ politics are unlikely to receive the kinds of attention that HB2 did. While participation by companies is transnational, it is wealthy western audiences that are the target.

Marketing teams do not have a mandate to be publicly-minded publishers, but they have, for most of the last century, acted as subsidizers of publicly-interested content, which was an argument for the public value of advertisers and a reason to tolerate interruptive advertisements. A model of published content produced independently from but in partnership with advertising dollars has been at the heart of journalism and entertainment production for much of the last century. Marketing campaigns that push traffic to corporate sites are doubly undercutting the model, first by commandeering audience time and second by undermining the subsidies for more independent content. It is a practice facilitated by digital tools, because content marketing does not show up in search engine results as advertising, and so is not screened by search engines trying to optimize for user preferences to avoid high levels of selling messages. There is a two-fold damaging effect, a loss of subsidies to journalistic content and a digital equivalency between brand vehicle content and publisher content. That presents a real problem when marketer content operates with a mandate to provide only positive, empowering messages geared toward core consumers, but the effects of content marketing might be limited, if the scale of the practice and its reception are not overly high.

While this thesis examined instances of commercial political communication, it does not fully address either the scale of the practice or its reception by audiences. Quantitative analysis 
can be used to make inroads into the scale, but it may be difficult to isolate branding vehicles disguised as ordinary content. Speaking to companies that make use of the practice as well as accessing marketing strategy documents could yield further insight. A significant question for future investigation is understanding which companies and which issues are most compatible with the practices of political content marketing and the cultivation of brand advocates. If there are certain issues and industries for which commercial communication is better suited, lawmakers and activists inclined to use commercial involvement as a measure of social support must be aware of the degree to which the efficacy of the strategy might be facilitated or limited by issue or actor.

Future research should investigate more directly the ways that commercial advocacy is received and interpreted by governments. Some work has been done in this arena already through investigation of the presence of private sector representatives at multi-lateral conferences (Shtern, Landry, \& Raboy, 2012). One approach is to conduct interviews with marketers and government officials. Another is to examine the documents that emerge from public consultations for evidence of legitimation of companies as speakers in public forums. A particularly fertile ground for this kind of study may be environmental assessments and consultations. Private energy companies, under pressure to provide evidence of sufficient consultation and provision for the public good, have increasingly turned to social media to create advocates and public support for the construction of pipelines and dams (Gunster, 2017). An important element of that research will be historical work on the treatment of commercial enterprises at important stages of the development of public communications platforms.

\section{CONCLUSION}

The digital acceleration of the overlap between commercial, political, and social life necessitates a reassessment of societies' mechanisms for understanding and communicating shared 
values and empirical grounding. An important part of Zizi Papacharissi's (2010) "hybrid geographies" of democracy is the commercial sphere and commercial actors, who see value in cultivating segments of the population that are affectively attached to them and their behaviours, and whose customers find in them powerful proxies for certain political feelings. While scholars, including Jurgen Habermas, know people spend more of their time in commercialized environments and theorize about its impact on public discourse, they tend to restrict their understanding of for-profit actors to those directly involved in telecommunications. Joseph Turow and Nick Couldry expanded this view to include advertisers as manipulators of the published content individuals view while online, but that research still centered on content publishers as a separate category from commercial entities generally. With the advent and near-ubiquitous adoption of content-hungry platforms as branding vehicles, starting with individual websites and progressing to blogging and other social media, it is not just media companies that are publishers. Much of the research on the changes that social media has brought to the communications landscape has praised the way social media makes media consumers into media producers. The conclusion drawn has often been that the ability of audiences produce content has a leveling effect, making ordinary citizens and powerful actors, such as politicians and telecommunications companies, digital equals. One argument that this thesis has made is that the affordances social media platforms make for companies of all kinds, including architecture that allows marketers to track engagement and data on their followers in ways that ordinary users cannot, has, in effect, empowered all companies with tools formerly reserved for publishers. Whether that will provide consumers with more opportunities to rationalize economic power or further isolate citizens in personalized communications environments remains to be seen. 


\section{APPENDiX A: SUMMARY OF CASE AND DATABASE}

\begin{tabular}{|c|c|c|c|c|c|c|c|c|c|}
\hline Company & Position & $\begin{array}{l}\text { Type of } \\
\text { Company }\end{array}$ & Product & $\begin{array}{l}\text { Date } \\
\text { (approximate) }\end{array}$ & $\begin{array}{l}\text { HB2 in } \\
\text { social } \\
\text { media }\end{array}$ & $\begin{array}{l}\text { Social Media } \\
\text { Feed Content }\end{array}$ & Location & $\begin{array}{l}\text { Collected } \\
\text { Materials }\end{array}$ & Notes \\
\hline Lionsgate & against & $\begin{array}{l}\text { publicly } \\
\text { traded }\end{array}$ & $\begin{array}{l}\text { film and } \\
\text { television }\end{array}$ & 30-Mar-16 & No & $\begin{array}{l}\text { upcoming } \\
\text { shows and } \\
\text { their stars }\end{array}$ & $\begin{array}{l}\text { Santa } \\
\text { Monica, } \\
\text { California }\end{array}$ & news articles & \\
\hline $\begin{array}{l}\mathrm{A}+\mathrm{E} \\
\text { Network }\end{array}$ & against & $\begin{array}{l}\text { owned by } \\
\text { Disney }\end{array}$ & $\begin{array}{l}\text { film and } \\
\text { television }\end{array}$ & 30-Mar-16 & No & $\begin{array}{l}\text { upcoming } \\
\text { shows and } \\
\text { their stars }\end{array}$ & $\begin{array}{l}\text { New York, } \\
\text { New York }\end{array}$ & news articles & \\
\hline $\begin{array}{l}\text { Google } \\
\text { Ventures }\end{array}$ & against & $\begin{array}{l}\text { owned by } \\
\text { Alphabet Inc }\end{array}$ & tech & 01-Apr-16 & No & $\begin{array}{l}\text { highlighting } \\
\text { portfolio, } \\
\text { management } \\
\text { tips, design } \\
\text { issues }\end{array}$ & $\begin{array}{l}\text { Mountain } \\
\text { View, } \\
\text { California }\end{array}$ & $\begin{array}{l}\text { industry } \\
\text { magazine } \\
\text { article }\end{array}$ & \\
\hline FOX TV & against & $\begin{array}{l}\text { Publicly } \\
\text { traded, } \\
\text { subsidiary of } \\
\text { 21st Century } \\
\text { Fox }\end{array}$ & $\begin{array}{l}\text { film and } \\
\text { television }\end{array}$ & 30-Mar-16 & No & $\begin{array}{l}\text { upcoming } \\
\text { shows and } \\
\text { their stars }\end{array}$ & $\begin{array}{l}\text { Los Angeles, } \\
\text { California }\end{array}$ & news stories & \\
\hline NASCAR & against & $\begin{array}{l}\text { private } \\
\text { company }\end{array}$ & $\begin{array}{l}\text { entertainm } \\
\text { ent }\end{array}$ & 22-Apr-16 & No & $\begin{array}{l}\text { fan } \\
\text { interaction, } \\
\text { play by play, } \\
\text { candid } \\
\text { moments, } \\
\text { national days } \\
\text { of celebration, } \\
\text { brand } \\
\text { partnerships }\end{array}$ & $\begin{array}{l}\text { Daytona } \\
\text { Beach, } \\
\text { Florida }\end{array}$ & news article & $\begin{array}{l}\text { NASCAR } \\
\text { took position } \\
\text { against } \\
\text { Indiana } \\
\text { religious } \\
\text { freedom bill }\end{array}$ \\
\hline $\begin{array}{l}\text { International } \\
\text { Market } \\
\text { Center }\end{array}$ & against & $\begin{array}{l}\text { private } \\
\text { company }\end{array}$ & $\begin{array}{l}\text { home } \\
\text { furnishing }\end{array}$ & 04-Apr-16 & No & $\begin{array}{l}\text { fan } \\
\text { interaction, } \\
\text { photos, }\end{array}$ & $\begin{array}{l}\text { High Point, } \\
\text { NC }\end{array}$ & $\begin{array}{l}\text { letter to the } \\
\text { editor from } \\
\text { CEO }\end{array}$ & \\
\hline 23andme & against & $\begin{array}{l}\text { privately } \\
\text { owned, three } \\
\text { locations }\end{array}$ & $\begin{array}{l}\text { tech/geneti } \\
\text { cs }\end{array}$ & 18-Apr-16 & No & $\begin{array}{l}\text { customer } \\
\text { service } \\
\text { interaction, } \\
\text { genetics news }\end{array}$ & $\begin{array}{l}\text { Mountain } \\
\text { View, } \\
\text { California }\end{array}$ & blog posts & $\begin{array}{l}\text { announced } \\
\text { on company } \\
\text { blog, found } \\
\text { via the } \\
\text { Wayback } \\
\text { Machine }\end{array}$ \\
\hline Instacart & against & $\begin{array}{l}\text { private, } \\
\text { high-value }\end{array}$ & $\begin{array}{l}\text { tech/grocer } \\
\text { ies }\end{array}$ & 02-Мay-16 & No & $\begin{array}{l}\text { customer } \\
\text { service, } \\
\text { memes, } \\
\text { holidays }\end{array}$ & $\begin{array}{l}\text { San } \\
\text { Francisco, } \\
\text { California }\end{array}$ & none & $\begin{array}{l}\text { signed a brief } \\
\text { with HRC } \\
\text { supporting } \\
\text { DOJ legal } \\
\text { action }\end{array}$ \\
\hline $\begin{array}{l}\text { Honest } \\
\text { Company }\end{array}$ & against & $\begin{array}{l}\text { private, } \\
\text { multi- } \\
\text { national }\end{array}$ & $\begin{array}{l}\text { organic } \\
\text { food and } \\
\text { baby stuff, } \\
\text { "Made to } \\
\text { Matter" } \\
\text { brand, B } \\
\text { Corps }\end{array}$ & 02-Мay-16 & No & $\begin{array}{l}\text { interactions } \\
\text { with } \\
\text { customers, } \\
\text { quotes, } \\
\text { organics and } \\
\text { organics } \\
\text { legislation }\end{array}$ & $\begin{array}{l}\text { Santa } \\
\text { Monica, } \\
\text { California }\end{array}$ & none & $\begin{array}{l}\text { Jessica Alba's } \\
\text { company, } \\
\text { Alba did not } \\
\text { sign }\end{array}$ \\
\hline $\begin{array}{l}\text { United } \\
\text { Guarantee } \\
\text { Corporation }\end{array}$ & against & $\begin{array}{l}\text { private, } \\
\text { multi- } \\
\text { national }\end{array}$ & $\begin{array}{l}\text { mortgages, } \\
\text { insurance }\end{array}$ & 02-May-16 & No & rarely used & $\begin{array}{l}\text { Greensboro, } \\
\text { NC }\end{array}$ & none & $\begin{array}{l}\text { subsequently } \\
\text { sold to Arch } \\
\text { Capital by } \\
\text { AIG }\end{array}$ \\
\hline $\begin{array}{l}\text { Cabot } \\
\text { Creamery }\end{array}$ & against & $\begin{array}{l}\text { private, } \\
1000+ \\
\text { employees }\end{array}$ & $\begin{array}{l}\text { dairy, } \quad \text { B } \\
\text { Corp }\end{array}$ & 02-May-16 & No & $\begin{array}{l}\text { recipes, staff } \\
\text { activities, } \\
\text { holiday } \\
\text { content }\end{array}$ & $\begin{array}{l}\text { Montpelier, } \\
\text { Vermont }\end{array}$ & none & \\
\hline $\begin{array}{l}\text { Castlight } \\
\text { Health, } \\
\text { Incorporated }\end{array}$ & against & $\begin{array}{l}\text { publicly } \\
\text { traded }\end{array}$ & $\begin{array}{l}\text { health } \\
\text { benefits }\end{array}$ & 02-Мay-16 & No & $\begin{array}{l}\text { news, press } \\
\text { coverage of } \\
\text { their research }\end{array}$ & $\begin{array}{l}\text { San } \\
\text { Francisco, } \\
\text { California }\end{array}$ & none & \\
\hline
\end{tabular}




\begin{tabular}{|c|c|c|c|c|c|c|c|c|c|}
\hline & & & $\begin{array}{l}\text { platform/te } \\
\text { ch }\end{array}$ & & & & & & \\
\hline $\begin{array}{l}\text { Willis } \\
\text { Towers } \\
\text { Watson }\end{array}$ & against & $\begin{array}{l}\text { publicly } \\
\text { traded, } \\
\text { multi- } \\
\text { national }\end{array}$ & brokerage & 02-May-16 & Yes & $\begin{array}{l}\text { play by play } \\
\text { of } \\
\text { conferences, } \\
\text { HR feed } \\
\text { aimed at } \\
\text { employee } \\
\text { engagement at } \\
\text { multinationals }\end{array}$ & London, UK & $\begin{array}{l}\text { Facebook } \\
\text { post }\end{array}$ & \\
\hline Merck & against & $\begin{array}{l}\text { publicly } \\
\text { traded, } \\
\text { multi- } \\
\text { national }\end{array}$ & $\begin{array}{l}\text { pharmaceu } \\
\text { tical } \\
\text { developme } \\
\text { nt }\end{array}$ & 02-Мay-16 & No & $\begin{array}{l}\text { international } \\
\text { awareness } \\
\text { days, } \\
\text { employee } \\
\text { initiatives }\end{array}$ & $\begin{array}{l}\text { Kenilworth, } \\
\text { New Jersey }\end{array}$ & none & \\
\hline IKEA US & against & $\begin{array}{l}\text { private, } \\
\text { multi- } \\
\text { national }\end{array}$ & $\begin{array}{l}\text { furniture } \\
\text { store }\end{array}$ & 02-May-16 & No & $\begin{array}{l}\text { new products, } \\
\text { sustainability } \\
\text { tips, in store } \\
\text { events }\end{array}$ & $\begin{array}{l}\text { Pennsylvania, } \\
\text { USA }\end{array}$ & none & \\
\hline $\begin{array}{l}\text { New Seasons } \\
\text { Market }\end{array}$ & against & private chain & market & 21-Apr-16 & No & $\begin{array}{l}\text { highlight } \\
\text { efforts to } \\
\text { include } \\
\text { transgender } \\
\text { employees }\end{array}$ & $\begin{array}{l}\text { Portland, } \\
\text { Oregon }\end{array}$ & none & \\
\hline $\begin{array}{l}\text { Seventh } \\
\text { Generation }\end{array}$ & against & private & $\begin{array}{l}\text { sustainable } \\
\text { household } \\
\text { products, } \\
\text { B Corp }\end{array}$ & 31-Mar-16 & Yes & $\begin{array}{l}\text { brand quizzes, } \\
\text { household } \\
\text { tips, baby } \\
\text { pictures, } \\
\text { politics } \\
\text { (especially } \\
\text { environmental } \\
\text { ism) }\end{array}$ & $\begin{array}{l}\text { Burlington, } \\
\text { VT }\end{array}$ & $\begin{array}{l}\text { Tweets, blog } \\
\text { post }\end{array}$ & $\begin{array}{l}\text { Venture arm } \\
\text { is in Raleigh, } \\
\text { NC }\end{array}$ \\
\hline $\begin{array}{l}\text { Redwoods } \\
\text { Group }\end{array}$ & against & $\begin{array}{l}\text { private, part } \\
\text { of larger } \\
\text { insurance } \\
\text { group }\end{array}$ & $\begin{array}{l}\text { Insurance } \\
\text { group, B } \\
\text { Corporatio } \\
\mathrm{n}\end{array}$ & 30-Mar-16 & Yes & $\begin{array}{l}\text { facts about } \\
\text { sexual abuse, } \\
\text { insurance, B } \\
\text { Corps }\end{array}$ & $\begin{array}{l}\text { Morrisville, } \\
\text { NC }\end{array}$ & Tweets & $\begin{array}{l}\text { fundraised } \\
\text { for LGBTQ } \\
\text { orgs and } \\
\text { groups } \\
\text { fighting } \\
\text { HB2, CEO } \\
\text { on record } \\
\text { about the bill } \\
\text { impacting } \\
\text { recruitment }\end{array}$ \\
\hline $\begin{array}{l}\text { Braeburn } \\
\text { Pharmaceutic } \\
\text { als }\end{array}$ & against & private & $\begin{array}{l}\text { pharmaceu } \\
\text { tical } \\
\text { developme } \\
\text { nt }\end{array}$ & 29-Mar-16 & NA & rarely used & Princeton, NJ & $\begin{array}{l}\text { Press } \\
\text { release, } \\
\text { Twitter post } \\
\text { circulated by } \\
\text { local media }\end{array}$ & $\begin{array}{l}\text { Significant } \\
\text { properties in } \\
\text { NC, } \\
\text { Statement } \\
\text { circulated } \\
\text { through news } \\
\text { media }\end{array}$ \\
\hline $\begin{array}{l}\text { Deutsche } \\
\text { Bank }\end{array}$ & against & $\begin{array}{l}\text { publicly } \\
\text { traded }\end{array}$ & banking & 12-Apr-16 & No & $\begin{array}{l}\text { conferences, } \\
\text { HR initiatives, } \\
\text { diversity in } \\
\text { the workplace }\end{array}$ & $\begin{array}{l}\text { Frankfurt, } \\
\text { Germany }\end{array}$ & Blog post & \\
\hline $\begin{array}{l}\text { The Boyd } \\
\text { Company }\end{array}$ & against & private & consulting & 31-Mar-16 & No & $\begin{array}{l}\text { business } \\
\text { climate, } \\
\text { corporate site } \\
\text { selection } \\
\text { news, } \\
\text { founder's } \\
\text { travels }\end{array}$ & Princeton, NJ & Blog post & \\
\hline $\begin{array}{l}\text { High Point } \\
\text { Market } \\
\text { Authority }\end{array}$ & against & private & $\begin{array}{l}\text { furniture } \\
\text { market }\end{array}$ & 28-Mar-16 & Yes & $\begin{array}{l}\text { photos from } \\
\text { the market, } \\
\text { customer } \\
\text { interaction, } \\
\text { furniture } \\
\text { maker } \\
\text { highlights }\end{array}$ & $\begin{array}{l}\text { High Point, } \\
\text { North } \\
\text { Carolina }\end{array}$ & $\begin{array}{l}\text { Tweets, } \\
\text { letter to the } \\
\text { editor, press } \\
\text { release, PBS } \\
\text { documentary }\end{array}$ & $\begin{array}{l}\text { largest } \\
\text { market of its } \\
\text { kind in the } \\
\text { world, } \\
\text { massive } \\
\text { source of } \\
\text { cash for NC }\end{array}$ \\
\hline
\end{tabular}




\begin{tabular}{|c|c|c|c|c|c|c|c|c|c|}
\hline $\begin{array}{l}\text { Myriad } \\
\text { Media }\end{array}$ & against & private & $\begin{array}{l}\text { production } \\
\text { studio, } \\
\text { advertising } \\
\text { agency }\end{array}$ & 23-Mar-16 & Yes & $\begin{array}{l}\text { social justice } \\
\text { (earthquakes, } \\
\text { HB2), } \\
\text { highlighting } \\
\text { media } \\
\text { projects, tech } \\
\text { and } \\
\text { production } \\
\text { news }\end{array}$ & $\begin{array}{l}\text { Raleigh, } \\
\text { North } \\
\text { Carolina }\end{array}$ & $\begin{array}{l}\text { Tweets, } \\
\text { website page }\end{array}$ & \\
\hline $\begin{array}{l}\text { Osceola } \\
\text { Studios }\end{array}$ & against & private & $\begin{array}{l}\text { recording } \\
\text { studios }\end{array}$ & 21-Apr-16 & No & $\begin{array}{l}\text { local scene, } \\
\text { recording } \\
\text { artists, sound } \\
\text { engineering } \\
\text { news }\end{array}$ & Raleigh, NC & none & \\
\hline $\begin{array}{l}\text { Allscripts } \\
\text { Healthcare } \\
\text { Solutions }\end{array}$ & against & $\begin{array}{l}\text { publicly } \\
\text { traded }\end{array}$ & $\begin{array}{l}\text { health } \\
\text { insurance }\end{array}$ & 02-May-16 & No & $\begin{array}{l}\text { conferences, } \\
\text { spotlighting } \\
\text { employees, } \\
\text { company } \\
\text { blog, } \\
\text { insurance } \\
\text { related news } \\
\text { items }\end{array}$ & $\begin{array}{l}\text { Chicago, } \\
\text { Illinois }\end{array}$ & none & \\
\hline $\begin{array}{l}\text { AIG } \\
\text { Insurance }\end{array}$ & against & $\begin{array}{l}\text { publicly } \\
\text { traded, } \\
\text { multi- } \\
\text { national }\end{array}$ & insurance & 02-May-16 & No & $\begin{array}{l}\text { interactions } \\
\text { with } \\
\text { customers, } \\
\text { updates on } \\
\text { products }\end{array}$ & $\begin{array}{l}\text { New York, } \\
\text { New York }\end{array}$ & none & \\
\hline Yadkin Bank & against & private & Banking & 02-May-16 & NA & NA & $\begin{array}{l}\text { Elkin, North } \\
\text { Carolina }\end{array}$ & none & $\begin{array}{l}\text { merged with } \\
\text { First National } \\
\text { Bank in } 2017\end{array}$ \\
\hline $\begin{array}{l}\text { Production } \\
\text { Solutions }\end{array}$ & against & private & Marketing & 15-Apr-16 & No & $\begin{array}{l}\text { advice for } \\
\text { marketing for } \\
\text { philantropy } \\
\text { and charities }\end{array}$ & $\begin{array}{l}\text { Vienna, } \\
\text { Virginia }\end{array}$ & blog post & \\
\hline Alcoa, Inc & against & $\begin{array}{l}\text { publicly } \\
\text { traded }\end{array}$ & $\begin{array}{l}\text { manufactu } \\
\text { ring }\end{array}$ & 21-Apr-16 & No & $\begin{array}{l}\text { Company } \\
\text { history, } \\
\text { sustainability } \\
\text { efforts, Alcoa } \\
\text { in the press }\end{array}$ & $\begin{array}{l}\text { New York, } \\
\text { New York }\end{array}$ & none & \\
\hline $\begin{array}{l}\text { BASF } \\
\text { Corporation } \\
\end{array}$ & against & $\begin{array}{l}\text { publicly } \\
\text { traded }\end{array}$ & $\begin{array}{l}\text { chemical } \\
\text { manufactu } \\
\text { ring }\end{array}$ & 21-Apr-16 & No & $\begin{array}{l}\text { announcemen } \\
\text { ts of plant } \\
\text { openings, } \\
\text { social causes, } \\
\text { international } \\
\text { days of } \\
\text { celebrations, } \\
\text { conferences, } \\
\text { products, } \\
\text { sustainability }\end{array}$ & $\begin{array}{l}\text { Ludwigshafe } \\
\text { n, Germany; } \\
\text { Cleveland, } \\
\text { Ohio }\end{array}$ & none & \\
\hline $\begin{array}{l}\text { Ben and } \\
\text { Jerry's }\end{array}$ & against & $\begin{array}{l}\text { publicly } \\
\text { traded }\end{array}$ & $\begin{array}{l}\text { ice cream, } \\
\text { B Corp }\end{array}$ & 29-Mar-16 & Yes & $\begin{array}{l}\text { also made a } \\
\text { long and } \\
\text { detailed blog } \\
\text { post, as well } \\
\text { as a steady } \\
\text { stream of } \\
\text { content in } \\
\text { support of } \\
\text { progressive } \\
\text { causes, owned } \\
\text { by Unilever }\end{array}$ & $\begin{array}{l}\text { South } \\
\text { Burlington, } \\
\text { Vermont } \\
\end{array}$ & $\begin{array}{l}\text { blog post, } \\
\text { tweets }\end{array}$ & \\
\hline $\begin{array}{l}\text { Cascade } \\
\text { Engineering }\end{array}$ & against & private & $\begin{array}{l}\text { plastics } \\
\text { and others, } \\
\text { B Corp }\end{array}$ & 21-Apr-16 & No & rarely used & $\begin{array}{l}\text { Grand } \\
\text { Rapids, } \\
\text { Michigan }\end{array}$ & none & \\
\hline Dansko|Etsy & against & $\begin{array}{l}\text { publicly } \\
\text { traded, } \\
\text { multi- } \\
\text { national }\end{array}$ & $\begin{array}{l}\text { tech/platfo } \\
\text { rm for } \\
\text { crafts, B } \\
\text { Corp }\end{array}$ & 21-Apr-16 & No & $\begin{array}{l}\text { made an } \\
\text { announcemen } \\
\mathrm{t} \quad \text { on } \\
\text { Medium.com }\end{array}$ & $\begin{array}{l}\text { Brooklyn, } \\
\text { New York }\end{array}$ & $\begin{array}{ll}\text { post on } \\
\text { Medium }\end{array}$ & $\begin{array}{l}\text { CEO from } \\
\mathrm{NC} \text { made an } \\
\text { announceme } \\
\text { nt on } \\
\text { Medium.com }\end{array}$ \\
\hline
\end{tabular}




\begin{tabular}{|c|c|c|c|c|c|c|c|c|c|}
\hline $\begin{array}{l}\text { Green } \\
\text { Mountain } \\
\text { Power }\end{array}$ & against & private & $\begin{array}{l}\text { power } \\
\text { utility, B } \\
\text { Corp }\end{array}$ & 21-Apr-16 & No & $\begin{array}{l}\text { B Corps } \\
\text { boosting, } \\
\text { sustainability } \\
\text { news, } \\
\text { highlighting } \\
\text { products (like } \\
\text { Tesla } \\
\text { batteries), } \\
\text { customer } \\
\text { interaction, } \\
\text { storm updates }\end{array}$ & $\begin{array}{l}\text { Colchester, } \\
\text { Vermont }\end{array}$ & none & \\
\hline Kickstarter & against & private & $\begin{array}{l} \\
\\
\\
\text { crowdfund } \\
\text { ing, B } \\
\text { Corp }\end{array}$ & 06-Apr-16 & Yes & $\begin{array}{l}\text { highlighting } \\
\text { interesting } \\
\text { projects, news } \\
\text { stories, } \\
\text { announced } \\
\text { hostility to } \\
\text { HB2 via B } \\
\text { Corps } \\
\text { involvement }\end{array}$ & $\begin{array}{l}\text { Greenpoint, } \\
\text { Brooklyn }\end{array}$ & tweets & \\
\hline KPMG & against & $\begin{array}{l}\text { private, } \\
\text { multi- } \\
\text { national }\end{array}$ & $\begin{array}{l}\text { investing } \\
\text { agency }\end{array}$ & 21-Apr-16 & No & $\begin{array}{l}\text { facts, expert } \\
\text { testimonials, } \\
\text { advice for } \\
\text { investors }\end{array}$ & Netherlands & none & \\
\hline $\begin{array}{l}\text { Live Nation } \\
\text { Entertainmen } \\
\mathrm{t}\end{array}$ & against & $\begin{array}{l}\text { publicly } \\
\text { traded }\end{array}$ & $\begin{array}{l}\text { entertainm } \\
\text { ent }\end{array}$ & 20-Apr-16 & No & $\begin{array}{l}\text { customer } \\
\text { interaction, } \\
\text { concert } \\
\text { announcemen } \\
\text { ts, celebrity } \\
\text { photos }\end{array}$ & $\begin{array}{l}\text { Beverly Hills, } \\
\text { California }\end{array}$ & $\begin{array}{l}\text { industry } \\
\text { magazine } \\
\text { article } \\
\end{array}$ & $\begin{array}{l}\text { frequently } \\
\text { materially } \\
\text { supportive of } \\
\text { LGBTQ } \\
\text { issues }\end{array}$ \\
\hline $\begin{array}{l}\text { New } \\
\text { Belgium } \\
\text { Brewing }\end{array}$ & against & private & $\begin{array}{l}\text { craft beer } \\
\text { brewery, B } \\
\text { Corp }\end{array}$ & 24-Mar-16 & Yes & $\begin{array}{l}\text { beer releases, } \\
\text { puns, national } \\
\text { days for } \\
\text { different } \\
\text { causes, social } \\
\text { justice content }\end{array}$ & $\begin{array}{l}\text { Asheville, } \\
\text { NC }\end{array}$ & $\begin{array}{l} \\
\text { tweets, } \\
\text { crowdfundin } \\
\text { g campaign, } \\
\text { news articles }\end{array}$ & $\begin{array}{l}\text { sustainability } \\
\text { focus, } \\
\text { created } \\
\text { funding } \\
\text { campaign } \\
\text { against the } \\
\text { bill }\end{array}$ \\
\hline $\begin{array}{l}\text { Mystery } \\
\text { Brewing } \\
\text { Company }\end{array}$ & against & private & $\begin{array}{l}\text { craft beer } \\
\text { brewery }\end{array}$ & 24-Mar-16 & Yes & $\begin{array}{l}\text { musical acts at } \\
\text { the pub, food } \\
\text { specials, } \\
\text { festivals, beer } \\
\text { releases }\end{array}$ & $\begin{array}{l}\text { Hillsborough, } \\
\text { NC }\end{array}$ & $\begin{array}{l}\text { tweets, } \\
\text { crowdfundin } \\
\text { g campaign } \\
\text { statement, } \\
\text { instagram } \\
\text { posts }\end{array}$ & $\begin{array}{l}\text { helped } \\
\text { organize } \\
\text { special brew } \\
\text { for the cause, } \\
\text { is not a B } \\
\text { Corps }\end{array}$ \\
\hline $\begin{array}{l}\text { Ponysaurus } \\
\text { Brewing } \\
\end{array}$ & against & private & $\begin{array}{l}\text { craft beer } \\
\text { brewery }\end{array}$ & unclear & Yes & $\begin{array}{l}\text { available } \\
\text { products, day } \\
\text { to day } \\
\text { operations }\end{array}$ & $\begin{array}{l}\text { Durham, } \\
\text { North } \\
\text { Carolina }\end{array}$ & $\begin{array}{l}\text { tweets, } \\
\text { crowdfundin } \\
\mathrm{g} \text { campaign } \\
\text { statement, } \\
\text { news } \\
\text { articles, } \\
\text { instagram } \\
\text { posts }\end{array}$ & $\begin{array}{l}\text { helped } \\
\text { organize } \\
\text { special brew } \\
\text { for the cause, } \\
\text { is not a B } \\
\text { Corps }\end{array}$ \\
\hline Patagonia & against & private & $\begin{array}{l}\text { outdoor } \\
\text { gear, B } \\
\text { Corp }\end{array}$ & 21-Apr-16 & Yes & $\begin{array}{l}\text { sustainability, } \\
\text { customer } \\
\text { interaction, } \\
\text { outdoor } \\
\text { photos, family } \\
\text { initiatives, fair } \\
\text { trade content }\end{array}$ & $\begin{array}{l}\text { Ventura, } \\
\text { California }\end{array}$ & $\begin{array}{l}\text { tweets, } \\
\text { instagram } \\
\text { posts } \\
\end{array}$ & \\
\hline $\begin{array}{l}\text { Self-Help } \\
\text { Credit Union }\end{array}$ & against & private & banking & 29-Mar-16 & Yes & $\begin{array}{l}\text { history, social } \\
\text { initiatives } \\
\text { funded by } \\
\text { Self-Help, } \\
\text { legislation }\end{array}$ & $\begin{array}{l}\text { Durham, } \\
\text { North } \\
\text { Carolina }\end{array}$ & $\begin{array}{l}\text { Tweets, blog } \\
\text { post }\end{array}$ & \\
\hline $\begin{array}{l}\text { The Fresh } \\
\text { Market }\end{array}$ & against & $\begin{array}{l}\text { publicly } \\
\text { traded }\end{array}$ & groceries & 21-Apr-16 & Yes & $\begin{array}{l}\text { recipes, } \\
\text { customer } \\
\text { interaction, } \\
\text { holiday } \\
\text { content }\end{array}$ & $\begin{array}{l}\text { Greensboro, } \\
\text { North } \\
\text { Carolina }\end{array}$ & $\begin{array}{l}\text { Tweets, } \\
\text { website page }\end{array}$ & \\
\hline
\end{tabular}




\begin{tabular}{|c|c|c|c|c|c|c|c|c|c|}
\hline $\begin{array}{l}\text { Vanguard } \\
\text { Group }\end{array}$ & against & private & $\begin{array}{l}\text { Investment } \\
\text { agency }\end{array}$ & 21-Apr-16 & No & $\begin{array}{l}\text { customer } \\
\text { interaction, } \\
\text { financial } \\
\text { advice, blog } \\
\text { articles }\end{array}$ & $\begin{array}{l}\text { Malvern, } \\
\text { Pennsylvania }\end{array}$ & none & \\
\hline $\begin{array}{l}\text { Warby } \\
\text { Parker }\end{array}$ & against & private & $\begin{array}{l}\text { glasses } \\
\text { retailer }\end{array}$ & 21-Apr-16 & No & $\begin{array}{l}\text { customer } \\
\text { interaction, } \\
\text { event } \\
\text { announcemen } \\
\text { ts }\end{array}$ & $\begin{array}{l}\text { New York, } \\
\text { New York }\end{array}$ & none & \\
\hline Xerox & against & $\begin{array}{l}\text { publicly } \\
\text { traded }\end{array}$ & $\begin{array}{l}\text { paper, } \\
\text { logistics }\end{array}$ & 21-Apr-16 & Yes & $\begin{array}{l}\text { customer } \\
\text { interaction, } \\
\text { company } \\
\text { blog, tech and } \\
\text { logistics } \\
\text { trends }\end{array}$ & $\begin{array}{l}\text { Norwalk, } \\
\text { Connecticut }\end{array}$ & none & $\begin{array}{l}\text { CEO since } \\
\text { been } \\
\text { reorganized }\end{array}$ \\
\hline Pepsico & against & $\begin{array}{l}\text { publicly } \\
\text { traded }\end{array}$ & Soft drinks & 02-Apr-16 & Yes & contests, ads & $\begin{array}{l}\text { Purchase, } \\
\text { New York }\end{array}$ & tweets & $\begin{array}{l}\text { CEO tweeted } \\
\text { letter, is } \\
\text { outspoken on } \\
\text { a number of } \\
\text { issues, tends } \\
\text { not to cross } \\
\text { over into the } \\
\text { Pepsico } \\
\text { channel }\end{array}$ \\
\hline Hyatt & against & $\begin{array}{l}\text { publicly } \\
\text { traded }\end{array}$ & hotel chain & 01-Apr-16 & Yes & $\begin{array}{l}\text { sales, photos } \\
\text { of locations, } \\
\text { deals, food, } \\
\text { community } \\
\text { service } \\
\text { initiatives }\end{array}$ & $\begin{array}{l}\text { Chicago, } \\
\text { Illinois }\end{array}$ & tweets & $\begin{array}{l}\text { CEO signs, } \\
\text { company } \\
\text { channel } \\
\text { shares }\end{array}$ \\
\hline $\begin{array}{l}\text { Ingersoll- } \\
\text { Rand }\end{array}$ & against & $\begin{array}{l}\text { publicly } \\
\text { traded }\end{array}$ & $\begin{array}{l}\mathrm{A} / \mathrm{C} \text { and } \\
\text { environme } \\
\text { ntal } \\
\text { products }\end{array}$ & 25-Mar-16 & Yes & $\begin{array}{l}\text { sustainability } \\
\text { initiatives, } \\
\text { company } \\
\text { facts, } \\
\text { celebrating } \\
\text { holidays }\end{array}$ & $\begin{array}{l}\text { Dublin, } \\
\text { Ireland }\end{array}$ & tweets & \\
\hline $\begin{array}{l}\text { Dow } \\
\text { Chemical }\end{array}$ & against & $\begin{array}{l}\text { publicly } \\
\text { traded }\end{array}$ & $\begin{array}{l}\text { chemical } \\
\text { manufactu } \\
\text { ring }\end{array}$ & 24-Mar-16 & Yes & $\begin{array}{l}\text { news links, } \\
\text { corporate } \\
\text { sustainability } \\
\text { initiatives }\end{array}$ & $\begin{array}{l}\text { Midland, } \\
\text { Michigan }\end{array}$ & $\begin{array}{l}\text { Tweets from } \\
\text { main and } \\
\text { policy } \\
\text { accounts, } \\
\text { Policy } \\
\text { website }\end{array}$ & \\
\hline $\begin{array}{l}\text { Hewlett- } \\
\text { Packard }\end{array}$ & against & $\begin{array}{l}\text { publicly } \\
\text { traded }\end{array}$ & $\begin{array}{l}\text { computers } \\
\text { and tech }\end{array}$ & 02-Apr-16 & Yes & $\begin{array}{l}\text { customer } \\
\text { interaction, } \\
\text { holiday } \\
\text { content, } \\
\text { product } \\
\text { announcemen } \\
\text { ts }\end{array}$ & Palo Alto, NC & none & \\
\hline $\begin{array}{l}\text { Smiles by } \\
\text { Payet }\end{array}$ & against & private & dentist & 04-Apr-16 & No & $\begin{array}{l}\text { blog posts, } \\
\text { customer } \\
\text { interaction }\end{array}$ & $\begin{array}{l}\text { Charlotte, } \\
\text { North } \\
\text { Carolina }\end{array}$ & blog post & \\
\hline PayPal & against & $\begin{array}{l}\text { publicly } \\
\text { traded }\end{array}$ & tech & 23-Mar-16 & Yes & $\begin{array}{l}\text { ads, } \\
\text { influencer } \\
\text { content, } \\
\text { company } \\
\text { news }\end{array}$ & $\begin{array}{l}\text { San Jose, } \\
\text { California }\end{array}$ & $\begin{array}{l}\text { Tweets, } \\
\text { website page }\end{array}$ & \\
\hline $\begin{array}{l}\text { Baldwin } \\
\text { Insurance } \\
\text { and } \\
\text { Brokerage }\end{array}$ & for & private & insurance & 29-Mar-16 & NA & - & Charlotte, NC & & $\begin{array}{l}\text { Lisa Baldwin } \\
\text { ran for } \\
\text { senate, is a } \\
\text { GOP } \\
\text { supporter }\end{array}$ \\
\hline $\begin{array}{l}\text { Archangel } \\
\text { Michael } \\
\text { Orthodox } \\
\text { Christian } \\
\text { Bookstore }\end{array}$ & for & private & bookstore & 29-Mar-16 & NA & - & $\begin{array}{l}\text { Winston- } \\
\text { Salem, NC }\end{array}$ & & \\
\hline
\end{tabular}




\begin{tabular}{|c|c|c|c|c|c|c|c|c|c|}
\hline $\begin{array}{ll}S \quad \& \quad S \\
\text { Cleaning } & \\
\text { Services } & \end{array}$ & for & private & $\begin{array}{l}\text { cleaning } \\
\text { services }\end{array}$ & 29-Mar-16 & NA & - & $\begin{array}{l}\text { Raleigh, } \\
\text { North } \\
\text { Carolina }\end{array}$ & & \\
\hline $\begin{array}{l}\text { xG } \\
\text { Technologies }\end{array}$ & for & $\begin{array}{l}\text { publicly } \\
\text { traded }\end{array}$ & $\begin{array}{l}\text { wireless } \\
\text { communic } \\
\text { ations }\end{array}$ & 29-Mar-16 & No & $\begin{array}{l}\text { patents, } \\
\text { tradeshows, } \\
\text { tech } \\
\text { announcemen } \\
\text { ts }\end{array}$ & $\begin{array}{l}\text { Sarasota, } \\
\text { Florida }\end{array}$ & none & $\begin{array}{l}\text { very small } \\
\text { social media } \\
\text { presence, } \\
<1000 \\
\text { followers }\end{array}$ \\
\hline $\begin{array}{l}\text { Total Life } \\
\text { Changes }\end{array}$ & for & private & $\begin{array}{l}\text { network } \\
\text { marketing, } \\
\text { lifestyle }\end{array}$ & 29-Mar-16 & No & $\begin{array}{l}\text { contracter } \\
\text { signed, her } \\
\text { feed is } \\
\text { products and } \\
\text { family photos }\end{array}$ & $\begin{array}{l}\text { Macomb } \\
\text { Country, MI }\end{array}$ & & $\begin{array}{l}\text { signed as an } \\
\text { individual, } \\
\text { not on behalf } \\
\text { of the } \\
\text { company }\end{array}$ \\
\hline $\begin{array}{l}\text { Main Street } \\
\text { Investments, } \\
\text { LLC }\end{array}$ & for & private & $\begin{array}{l}\text { Investment } \\
\text { agency }\end{array}$ & 29-Mar-16 & NA & - & Concord, NC & & \\
\hline $\begin{array}{l}\text { Griffin Tile } \\
\text { and Marble }\end{array}$ & for & private & $\begin{array}{l}\text { tile } \\
\text { installation }\end{array}$ & 29-Mar-16 & NA & - & Mint Hill, NC & & \\
\hline $\begin{array}{l}\text { Mark } \\
\text { Godwin } \\
\text { Family } \\
\text { Farms }\end{array}$ & for & private & farm & 29-Mar-16 & NA & - & $\begin{array}{l}\text { New Grove, } \\
\text { NC }\end{array}$ & & \\
\hline $\begin{array}{l}\text { Lighthouse } \\
\text { Electric of } \\
\text { Charlotte }\end{array}$ & for & private & $\begin{array}{l}\text { electrician } \\
\mathrm{s}\end{array}$ & 29-Mar-16 & NA & - & Charlotte, NC & & \\
\hline $\begin{array}{l}\text { D Harward } \\
\text { Social } \\
\text { Marketing }\end{array}$ & for & private & marketing & 29-Mar-16 & No & $\begin{array}{l}\text { marketing } \\
\text { tips, links to } \\
\text { articles }\end{array}$ & $\begin{array}{l}\text { Davidson, } \\
\text { NC }\end{array}$ & & \\
\hline $\begin{array}{l}\text { Hasty Home } \\
\text { Resources }\end{array}$ & for & private & $\begin{array}{l}\text { home } \\
\text { repair }\end{array}$ & 29-Mar-16 & NA & - & Raleigh, NC & & \\
\hline $\begin{array}{l}\text { OmniChanne } \\
1 \text { Pro }\end{array}$ & for & private & $\begin{array}{l}\text { supply } \\
\text { chain } \\
\text { manageme } \\
\text { nt }\end{array}$ & 29-Mar-16 & No & $\begin{array}{l}\text { conference } \\
\text { presentation, } \\
\text { industry news }\end{array}$ & Charlotte, NC & LinkedIn & $\begin{array}{l}\text { very active } \\
\text { Baptist }\end{array}$ \\
\hline $\begin{array}{l}\text { Occupational } \\
\text { Health } \\
\text { Concepts }\end{array}$ & for & private & $\begin{array}{l}\text { physiother } \\
\text { apy }\end{array}$ & 29-Mar-16 & NA & - & Charlotte, NC & & \\
\hline $\begin{array}{l}\text { Beethoven's } \\
\text { piano } \\
\text { reveler's } \\
\text { studio }\end{array}$ & for & private & $\begin{array}{l}\text { music } \\
\text { school }\end{array}$ & 29-Mar-16 & NA & - & & & \\
\hline $\begin{array}{ll}\text { Collision } & \\
\text { Centre } & \text { of } \\
\text { Stanley } & \\
\text { County } & \\
\end{array}$ & for & private & $\begin{array}{l}\text { automotive } \\
\text { collision } \\
\text { centre }\end{array}$ & 29-Mar-16 & NA & - & $\begin{array}{l}\text { Albemarle, } \\
\text { NC }\end{array}$ & news article & \\
\hline $\begin{array}{l}\text { Heaven's } \\
\text { Best Carpet } \\
\text { Cleaning }\end{array}$ & for & private & $\begin{array}{l}\text { carpet } \\
\text { cleaning }\end{array}$ & 29-Mar-16 & NA & - & Charlotte, NC & news article & $\begin{array}{l}\text { Christian } \\
\text { values }\end{array}$ \\
\hline $\begin{array}{l}\text { ICI Lamp } \\
\text { Company }\end{array}$ & for & private & $\begin{array}{l}\text { lighting } \\
\text { fixtures }\end{array}$ & 29-Mar-16 & NA & - & Charlotte, NC & news article & \\
\hline Serlandscape & for & private & $\begin{array}{l}\text { landscapin } \\
\mathrm{g}\end{array}$ & 29-Mar-16 & NA & - & $\begin{array}{ll}\text { Indian } & \text { Trail, } \\
\text { NC } & \\
\end{array}$ & & \\
\hline $\begin{array}{l}\text { Comfort } \\
\text { Security }\end{array}$ & for & private & $\begin{array}{l}\text { Home } \\
\text { security }\end{array}$ & 29-Mar-16 & NA & - & Charlotte, NC & & \\
\hline $\begin{array}{l}\text { Green } \\
\text { Branch } \\
\text { Construction }\end{array}$ & for & private & $\begin{array}{l}\text { constructio } \\
\mathrm{n}\end{array}$ & 29-Mar-16 & No & $\begin{array}{l}\text { Renovations, } \\
\text { finished } \\
\text { projects, } \\
\text { client } \\
\text { interactions }\end{array}$ & Charlotte, NC & none & \\
\hline $\begin{array}{l}\text { Wood } \\
\text { Coating } \\
\text { Research } \\
\text { Group }\end{array}$ & for & private & $\begin{array}{l}\text { wood } \\
\text { coating }\end{array}$ & 29-Mar-16 & NA & - & $\begin{array}{l}\text { High Point, } \\
\text { NC }\end{array}$ & & \\
\hline
\end{tabular}




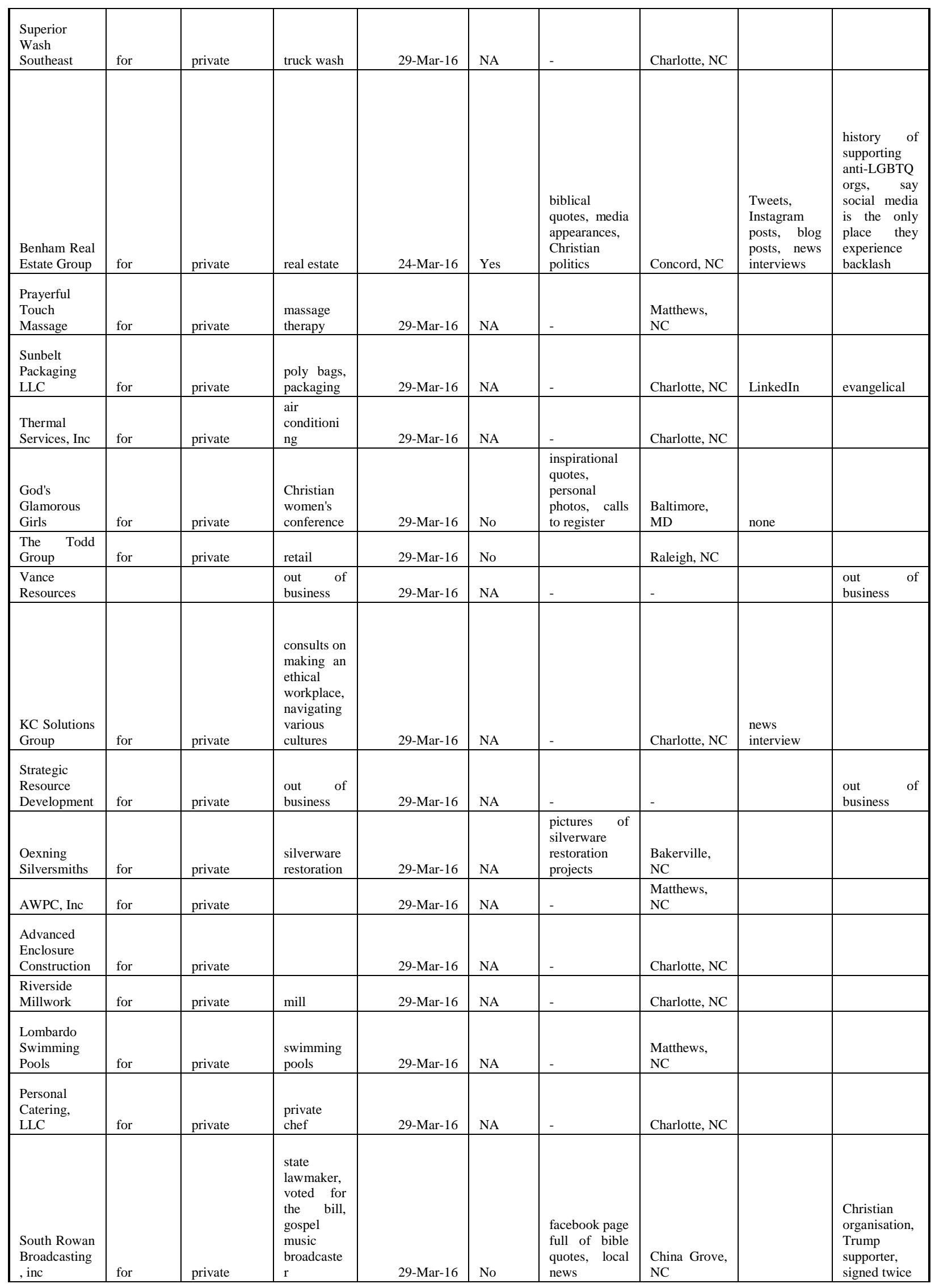




\begin{tabular}{|c|c|c|c|c|c|c|c|c|}
\hline Melatex, inc & for & private & $\begin{array}{l}\text { chemical } \\
\text { manufactu } \\
\text { ring }\end{array}$ & 29-Mar-16 & NA & - & Charlotte, NC & \\
\hline $\begin{array}{l}\text { Snyder } \\
\text { Packaging } \\
\end{array}$ & for & private & packaging & 29-Mar-16 & No & $\begin{array}{l}\text { product } \\
\text { announcemen } \\
\text { ts, } \\
\text { sustainability } \\
\text { initiatives }\end{array}$ & Concord, NC & \\
\hline $\begin{array}{l}\text { Pearl } \\
\text { Financing }\end{array}$ & for & private & $\begin{array}{l}\text { consultanc } \\
\text { y }\end{array}$ & 29-Mar-16 & No & $\begin{array}{l}\text { start up and } \\
\text { entrepreneurs } \\
\text { hip memes } \\
\text { and } \\
\text { encourageme } \\
\text { nt }\end{array}$ & $\begin{array}{l}\text { Morrisville, } \\
\text { NC }\end{array}$ & \\
\hline $\begin{array}{l}\text { Highwoods } \\
\text { Properties }\end{array}$ & for & private & $\begin{array}{l}\text { property } \\
\text { manageme } \\
\text { nt }\end{array}$ & 29-Mar-16 & No & $\begin{array}{l}\text { construction } \\
\text { sites, } \\
\text { conferences, } \\
\text { celebrating } \\
\text { national days, } \\
\text { charity } \\
\text { donations }\end{array}$ & Raleigh, NC & news article \\
\hline $\begin{array}{l}\text { McClees } \\
\text { Consulting }\end{array}$ & for & private & lobbyist & 29-Mar-16 & No & $\begin{array}{l}\text { hunting } \\
\text { politics }\end{array}$ & $\begin{array}{l}\text { Raleigh- } \\
\text { Durham, NC }\end{array}$ & none \\
\hline $\begin{array}{l}\text { To Your } \\
\text { Health } \\
\text { Bakery }\end{array}$ & for & private & bakery & 29-Mar-16 & No & $\begin{array}{l}\text { Photos of } \\
\text { cakes and } \\
\text { cookies, } \\
\text { memes about } \\
\text { GMOs and } \\
\text { farmers } \\
\text { markets, } \\
\text { occasional } \\
\text { personal or } \\
\text { Christian } \\
\text { message }\end{array}$ & $\begin{array}{l}\text { Winston- } \\
\text { Salem, NC }\end{array}$ & none \\
\hline Hanes Brand & neutral & $\begin{array}{l}\text { publicly } \\
\text { traded, } \\
\text { multi- } \\
\text { national }\end{array}$ & clothing & 30-Mar-16 & No & $\begin{array}{l}\text { customer } \\
\text { service }\end{array}$ & $\begin{array}{l}\text { Winston- } \\
\text { Salem, NC }\end{array}$ & $\begin{array}{l}\text { news article, } \\
\text { press release }\end{array}$ \\
\hline
\end{tabular}




\section{REFERENCES}

\#grabyourwallet. (n.d.) What we're about. Retrieved from

https://grabyourwallet.org/What\%20We're\%20About.html

$2^{\text {nd }}$ Vote. (n.d.) Who we are. Retrieved from https://2ndvote.com/who-we-are/

Alhouti, S., Johnson, C. M., \& Holloway, B. B. (2016). Corporate social responsibility authenticity: Investigating its antecedents and outcomes. Journal of Business Research, 69(3), 1242-1249.

Alvesson, M. and Skoldberg, K. (2009). Reflexive Methodology: Second Edition. Sage, London.

Arvidsson, A. (2008). The Ethical Economy of Customer Coproduction. Journal of Macromarketing 28 (4), 326-338.

Arvidsson, A. (2009). The Ethical Economy: Towards a post-capitalist theory of value. Capital \& Class $33(1), 13-29$.

Anderson, R. and Fetner, T. (2008). Economic inequality and intolerance: Attitudes towards homosexuality in 35 democracies. American Journal of Political Science 52 (4), p. 942-958.

Bai, M. (2012, July 17). How much has citizens united changed the political game? The New York Times Magazine. Retrieved from http://www.nytimes.com/2012/07/22/magazine/how-much-hascitizens-united-changed-the-political-game.html

Baker, S. A. (2012). From the criminal crowd to the "mediated crowd": The impact of social media on the 2011 English riots. Safer communities, 11(1), 40-49.

Barney, D. (2005). Communications Technology. UBC Press: Vancouver 
BBC News. (2016, April 5). Mississippi passes controversial 'religious freedom' bill. BBC News. Retrieved from http://www.bbc.com/news/world-us-canada-35971038

Becker, A. \& Copeland, L. (2016). Networked publics: How connective social media use facilitates political consumerism among LGBT Americans, Journal of Information Technology \& Politics (13) 1, 22-36, DOI: 10.1080/19331681.2015.1131655

Becker-Olsen, K., \& Simmons, C. J. (2002). When do social sponsorships enhance or dilute equity? Fit, message source, and the persistence of effects. NA-Advances in Consumer Research Volume 29.

Becker-Olsen, K. L., Cudmore, B. A., \& Hill, R. P. (2006). The impact of perceived corporate social responsibility on consumer behavior. Journal of business research, 59(1), 46-53.

Ben\&Jerry's. (2016, March 29). North Carolina's new discriminatory law tramples on lgbt rights. Retrieved from http://www.benjerry.com/whats-new/2016/north-carolina-lgbt-law

Benham Brothers. (2016a, March 29). Women and children deserve privacy and protection. Retrieved from http://benhambrothers.com/women-and-children-deserve-privacy-and-protection/

Benham Brothers. (2016b, April 5). Poisonous 'vine' surrounds its prey in America. Retrieved from http://benhambrothers.com/poisonous-vine-surrounds-its-prey-in-america/

Benham Brothers. (2016c, April 26). Why we're standing up to bullies in nc. Retrieved from http://benhambrothers.com/why-were-standing-up-to-bullies-in-n-c/

Berlin, D. (2011). Sustainable consumers and the state: Exploring how citizen's trust and distrust in institutions spur political consumption. Journal of Environmental Policy \& Planning 13 (3), 277295 
Berry, S. (2016, October 11). Here are 11 companies that directly fund planned parenthood. Breitbart. Retrieved from http://www.breitbart.com/big-government/2016/10/11/37-companies-directlyfund-planned-parenthood/

B Lab. (2017) How to become a b corp. Retrieved from https://www.bcorporation.net/become-a-bcorp/how-to-become-a-b-corp

Boothe, M. (2016, July 29). In the world of content marketing, the consumer is king. Adobe Digital Marketing Blog. Retrieved from https://blogs.adobe.com/digitalmarketing/customerexperience $/ 36819 /$

Boschini, A. (2016, March 28). High point market authority warns that house bill 2 could hurt attendance. Home Accents Today.

Brennan, R., \& Croft, R. (2012). The use of social media in B2B marketing and branding: An exploratory study. Journal of Customer Behaviour, 11(2), 101-115.

Bruns, A. (2008). Life beyond the public sphere: Towards a networked model for political deliberation. Information Polity 13 (1-2): pp. 65-79

Burgess, J. \& Matamoros-Fernandez, A. (2016). Mapping sociocultural controversies across digital media platforms: one week of \#gamergate on Twitter, YouTube and Tumblr. Communication Research and Practice 2(1), 79-96.

Burgess, J. and Bruns, A. (2016). Methodological innovation in precarious spaces: The case of Twitter. In Digital Methods for Social Science: An Interdisciplinary Guide to Research Innovation. by Roberts, S., Snee, H., Hine, C., Morey, Y., \& Watson, H. (Eds.). Springer, p. 17-33 
Callon, M., Lascoumes, P., \& Barth, Y. (2001). Acting in an uncertain world: An essay on technical democracy. Cambridge, MA: MIT Press.

Castells, M. (2007). Communication, power and counter-power in the network society. International journal of communication, 1(1), 29.

CBC News. (2016, April 6). Lionsgate moves tv production to B.C. after north carolina's anti-LGBTQ law. Retrieved from http://www.cbc.ca/news/business/lionsgate-north-carolina-bc-hb2-1.3522818

CBS North Carolina. (2016). 2 nc breweries creating 'don't be mean to people' beer in opposition to HB2. Retrieved from http://wncn.com/2016/04/12/2-nc-breweries-creating-dont-be-mean-to-peoplebeer-in-opposition-of-hb2/

Cervellon, M. C. (2012). Victoria's dirty secrets: Effectiveness of green not-for-profit messages targeting brands. Journal of Advertising, 41(4), 133-145.

Chappell, B. (2016, April 13). 'Don’t be mean' beer: 36 nc breweries sign up to sell brew aimed at bigotry. The Two Way, NPR. Retrieved from http://www.npr.org/sections/thetwoway/2016/04/13/474065811/dont-be-mean-beer-36-n-c-breweries-sign-up-to-sell-brew-aimed-at$\mathrm{hb} 2$

Charlotte Observer. (n.d.). About us. Retrieved from http://www.charlotteobserver.com/customerservice/about-us/

$\begin{array}{lllll}\text { Colorofchange.org. } & \text { (n.d.) } & \text { Past } & \text { campaigns. } & \text { Retrieved }\end{array}$ https://www.colorofchange.org/campaigns/past/ 
Coté, M. and Pybus, J. (2011). Learning to immaterial labour 2.0: Facebook and social networks. In Cognitive Capitalism, Education and Digital Labour (pp. 169-194) Michael A. Peters and Ergin Bulut (eds). New York: Peter Lang.

Couldry, N. and Turow, J. (2014). Advertising, big data and the clearance of the public realm: Marketers' new approaches to the content subsidy. International Journal of Communication 8, pp. 1710-1726.

Craver, R. (2016, July 13). HB2 likely reduced state's position in national ranking. Winston-Salem Journal. Retrieved from http://www.theboydcompany.com/pdf/WinstonSalem\%20Journal\%20HB2.pdf

Cummings, B. (2012). Benefit corporations: How to enforce a mandate to promote the public interest. Columbia Law Review, 578-627.

Cervellon, M. \& Galipienzo, D. (2015). Facebook pages content, does it really matter? Consumers' responses to luxury hotel posts with emotional and informational content, Journal of Travel \& Tourism Marketing (32)4, 428-437, DOI: 10.1080/10548408.2014.904260

Delli Carpini, M. (2004). Mediating democratic engagement: The impact of communications on citizens' involvement in political and civic life. Handbook of political communication research, 357-394.

Douglas, A. (2016, April 1). North Carolina's LGBT law may have impact on women, minorities. The Charlotte Observer. Retrieved from http://www.charlotteobserver.com/news/politicsgovernment/article69527867.html

Dow.com. (n.d.). About dow: Public policy. Retrieved from http://www.dow.com/en-us/about$\underline{\text { dow/public-policy }}$ 
Drew, J. (2017, February 24). NAACP urges national boycott of NC over HB2, other policies. The $\begin{array}{lll}\text { Charlotte } & \text { Observer. } & \text { Retrieved }\end{array}$ http://www.charlotteobserver.com/news/local/article134822519.html

Fausset, R. (2017, March 30). Bathroom law repeals leaves few pleased in North Carolina. New York Times. Retrieved from https://www.nytimes.com/2017/03/30/us/north-carolina-senate-acts-torepeal-restrictive-bathroom-law.html

Feitelberg, R. (2016, April 5). Unmoved by north carolina's new hb2 law, companies pledge their commitment to fairness and equality. Women's Wear Daily. Retrieved from http://wwd.com/fashion-news/fashion-scoops/brooks-brothers-north-carolina-hb2-10404251/

Fontein, D. (2016, July 14). How to build a brand advocacy program. Hootsuite. Retrieved from https://blog.hootsuite.com/community-management-tip-brand-advocacy-program/

Foster, T. (2014, February 20). Seven ways to identify and engage brand advocates. Forbes. Retrieved from https://www.forbes.com/sites/theyec/2014/02/20/seven-ways-to-identify-and-engage-brandadvocates/\#83ddba424c82

Fox46 Charlotte. (2016, March 30). Charlotte business owner voices support for HB2. Retrieved from http://www.fox46charlotte.com/news/local-news/114488345-story

Fox Business. (2016, May 10). N.C. bathroom law's impact on business. Retrieved from http://video.foxbusiness.com/v/4887024625001/nc-bathroom-laws-impact-onbusiness/\#sp=show-clips

France, L. R. (2014, May 9). Benham brothers lose hgtv show after 'anti-gay' remarks. CNN. Retrieved from http://www.cnn.com/2014/05/08/showbiz/tv/benham-brothers-hgtv/ 
Frankfurt am Main. (2016, April 12). Deutsche bank freezes job expansion plans in north carolina. Retrieved from https://www.db.com/newsroom_news/2016/medien/deutsche-bank-freezes-jobexpansion-plans-in-north-carolina-en-11535.htm

Fuchs, C. (2011). Web 2.0, prosumption, and surveillance. Surveillance \& Society (8)3. 288-309.

Fuchs, C. (2012). The contemporary world wide web: Social medium or new space of accumulation? The Political Economies of Media (pp. 201-220). Dwayne Winseck and Dal Yong Jin (eds.) Bloomsbury. New York.

Gambino, L. (2015, June 29). US supreme court refuses to let Texas close 10 abortion clinics. The Guardian. Retrieved from https://www.theguardian.com/us-news/2015/jun/29/supreme-court$\underline{\text { texas-abortion-clinics }}$

Garrigos-Simon, F. J., Lapiedra Alcamí, R., \& Barberá Ribera, T. (2012). Social networks and web 3.0: Their impact on the management and marketing of organizations. Management Decision, 50(10), 1880-1890.

Generosity by Indiegogo. (n.d.). Our mission. Retrieved from https://www.generosity.com/learn/about/

Gill, R. (2009). Media and Communication Research Methods. London: Sage.

Greenpeace International. (2014, October 15). Deutsche bank under pressure as chinese government joins $\begin{array}{lllll}\text { greenpeace, condemning } & \text { bungled }\end{array}$ http://www.greenpeace.org/international/en/press/releases/2014/Deutsche-Bank-under-pressureas-Chinese-Government-joins-Greenpeace-condemning-bungled-IPO/

Greer, C. F., \& Ferguson, D. A. (2011). Using Twitter for promotion and branding: A content analysis of local television Twitter sites. Journal of Broadcasting \& Electronic Media, 55(2), 198-214. 
Gregory, A. (2007). Involving stakeholders in developing corporate brands: The communication dimension. Journal of Marketing Management 23 (1-2), pp 59-73.

Groza, M. D., Pronschinske, M. R., \& Walker, M. (2011). Perceived organizational motives and consumer responses to proactive and reactive CSR. Journal of Business Ethics, 102(4), 639-652.

Grynbaum, M.M. \& Mahaswari, S. (2017, April 20). Fears of revolt from consumers felled o'reilly. Retrieved from https://www.nytimes.com/2017/04/20/business/media/fears-of-revolt-byconsumers-felled-bill-oreilly.html

Gunster, S. (2017, May). License to drill: Social license, environmental conflict, and Canadian resource development. Panel presentation at the annual meeting of the Canadian Communication Association, Toronto, Ontario.

Habermas, J. (1989). The Structural Transformation of the Public Sphere. Cambridge: The MIT Press. Translated by Thomas Burger with the assistance of Frederick Lawrence.

Hanes for Good. (n.d.) http://hanesforgood.com/governance/

Hanes. (2010, March 25). Hanes shares environmental responsibility via green advertising campaign, consumer website and marketing initiatives. $P R$ Newswire. Retrieved from http://www.prnewswire.com/news-releases/hanes-shares-environmental-responsibility-effortsvia-green-advertising-campaign-consumer-website-and-marketing-initiatives-89112307.html

Hanes Brands Inc. (2017, February 10). HanesBrands recognized by corporate responsibility magazine and ethical corporation. PSR Wire. Retrieved from http://ir.hanesbrands.com/phoenix.zhtml?c=200600\&p=irol-newsArticle\&ID=2215960 
Hansen, A. \& Machin, D. (2013). Media and Communication Research Methods. (pp. 85-114). UK: Palgrave MacMillan.

Hao, K. (2017, March 24). Behind the mystery group hitting breitbart where it hurts. Mother Jones. Retrieved from http://www.motherjones.com/media/2017/03/breitbart-sleeping-giants-ads/

Harfenist, E. and Cohen, A. (2016, March 30). North carolina's derided anti-trans law still finds its supporters. Vocativ. Retrieved from http://www.vocativ.com/303231/north-carolinas-deridedanti-trans-law-still-finds-its-supporters/

Hatch, M. J., \& Schultz, M. (2010). Toward a theory of brand co-creation with implications for brand governance. Journal of Brand Management, 17(8), 590-604.

Helmore, E. (2016, April 15). North Carolina reels from business backlash to anti-LGBT law. The Guardian. Retrieved from https://www.theguardian.com/world/2016/apr/15/north-carolina-lgbt$\underline{\text { law-business-backlash }}$

Hendry, J. (2006). Taking aim at business. Business \& Society, 45(1), 47-86. doi:10.1177/0007650305281849

Hess, J., \& Story, J. (2005). Trust-based commitment: multidimensional consumer-brand relationships. Journal of Consumer Marketing, 22(6), 313-322.

Hoge, P. (2016, June 10). Business battles the anti-LGBT backlash. Bizjournals.com. Retrieved from http://www.bizjournals.com/sanfrancisco/print-edition/2016/06/10/1gbt-business-boycott-hb2north-carolina-strava.html

Holliman, G., \& Rowley, J. (2014). Business to business digital content marketing: marketers’ perceptions of best practice. Journal of Research in Interactive Marketing, 8(4), 269-293. 
Howard, P. N. (2002). Network ethnography and the hypermedia organization: new media, new organizations, new methods. New Media \& Society 4 (4), 550-574.

HRC.org. (n.d.) Blog posts filtered by state. Retrieved from http://www.hrc.org/blog/filter/state/7229

HRC Staff. (2016, March 30). Bank of America, Miramax, American airlines, Uber join call for repeal of hb2. HRC.org. Retrieved from http://www.hrc.org/blog/bank-of-america-miramax-uber-join-90business-leaders-demanding-nc-repeal-a

Hughes, B. (2016, March 16). How to optimize your social media frequency. Social Media Week. Retrieved from https://socialmediaweek.org/blog/2016/03/optimize-social-media-time/

Inslee, I. (2016, April 5). Hey @ PayPal - Washington state and our \#1 economy is open for business. We are proud to stand for inclusion and innovation. Twitter.com. Retrieved from https://twitter.com/govinslee/status/717405454922436608

Issacharoff, S., \& Ortiz, D. R. (1999). Governing through intermediaries. Virginia Law Review, 16271670.

Jansen, B. J., Zhang, M., Sobel, K., \& Chowdury, A. (2009). Twitter power: Tweets as electronic word of mouth. Journal of the American society for information science and technology, 60(11), 21692188.

Johnson, L. (2012). Pluralism in corporate form: Corporate law and benefit corporations. Regent University Law Review 25 (2), p. 270-298.

Juris, J. S. (2012). Reflections on \#occupy everywhere: Social media, public space, and emerging logics of aggregation. American Ethnologist, 39(2), 259-279. 
Jurney, C. (2016, November 3). North carolina's 'bathroom bill' flushes away $\$ 600$ million in business and could dash governor's reelection hopes. Forbes. Retrieved from http://www.forbes.com/sites/corinnejurney/2016/11/03/north-carolinas-bathroom-bill-flushesaway-nearly-1-billion-in-business-and-governor-mccrorys-re-election-hopes/\#5973d8826eb5

Kardish, C. (2014, July). How north carolina turned so red so fast. Retrieved from http://www.governing.com/topics/politics/gov-north-carolina-southern-progressivism.html

Killian, J. (2016, March 30). The fallout from house bill 2 just keeps getting bigger. Greensboro News and Report. Retrieved from www.greensboro.com/news/local_news/the-fallout-from-house-billjust-keeps-gettig-bigger/article_3cd002

Kolevar, K. (2016a, March 23). Dow opposes \#NCGA attempt to undermine equality in charlotte. Let's focus on policies that make \#NC stronger and more competitive. Retrieved from https://twitter.com/dowpolicy/status/712681738749628420

Kolevar, K. (2016b, March 24). Dow is disappointed with the signing of NC \#HB2. We will continue to call for a comprehensive federal framework to ensure fairness for all. Retrieved from https://twitter.com/dowpolicy/status/712993845185757186

Kron, J. (2012, November 30). Red state, blue state: How the urban-rural divide is splitting America. The Atlantic. Retrieved from https://www.theatlantic.com/politics/archive/2012/11/red-state-bluecity-how-the-urban-rural-divide-is-splitting-america/265686/

Latour, B. (2005). Reassembling the social: an introduction to actor-network-theory. Oxford: Oxford University Press.

Lievrouw, L. (2011). Alternative and Activist New Media. Polity. 
Lee, M.-D. (2008). A review of the theories of corporate social responsibility: Its evolutionary path and the road ahead. International Journal of Management Reviews, 10, pp. 53-73.

Levitt, J. (2010). Confronting the impact of citizens united. Yale Law and Policy Review 29 (1), 217-234.

Lindgreen, A., \& Swaen, V. (2010). Corporate social responsibility. International Journal of Management Reviews, 12(1), 1-7.

Maheshwari, S. \& Wakabayashi, D. (2017, March 22). At\&t and johnson \& johnson pull ads from youtube. NYTimes. Retrieved from https://www.nytimes.com/2017/03/22/business/atampt-andjohnson-amp-johnson-pull-ads-from-youtube-amid-hate-speech-concerns.html

Malin, B.J. (2011). A very popular blog: The internet and the possibilities of publicity. New Media \& Society (13), 187-202.

Mangold, W. G., \& Faulds, D. J. (2009). Social media: The new hybrid element of the promotion mix. Business horizons, 52(4), 357-365.

Marres, N., \& Moats, D. (2015). Mapping controversies with social media: The case for symmetry. Social Media + Society, 1(2), 1-17.

Matten, D., \& Crane, A. (2005). Corporate citizenship: Toward an extended theoretical conceptualization. Academy of Management review, 30(1), 166-179.Marres, N. (2015). Why map issues? On controversy analysis as a digital method. Science, Technology \& Human Values, 40, $655-686$.

McCrory, P. (2016a, April 17). Interview by C. Todd. Meet the Press [Television broadcast]. New York City: NBC News. 
McCrory, P. (2016c, May 8). Interview by C. Wallace. Fox News Sunday [Television broadcast]. New York City: Fox News Channel.

McWilliams, A. and Siegel, D. (2011). Creating and capturing value: Strategic corporate responsibility, resource-based theory, and sustainable competitive advantage. Journal of Management 37(5), 1480-1495.

Micheletti, M., \& Stolle, D. (2012). Sustainable citizenship and the new politics of consumption. The Annals of the American Academy of Political and Social Science, 644(1), 88-120, doi:10.1177/0002716212454836.

Murray, A., \& Kline, C. (2015). Rural tourism and the craft beer experience: Factors influencing brand loyalty in rural North Carolina, USA. Journal of Sustainable Tourism, 23(8-9), 1198-1216.

Myers, E.L. and Jansen, K. (2016, April 12). Don't be mean to people a golden rule saison. Retrieved from https://www.generosity.com/community-fundraising/don-t-be-mean-to-people-a-goldenrule-saison

Neisser, D. (2017, March 22). Why marriot is a content marketing mecca. Advertising Age. Retrieved from http://adage.com/article/cmo-strategy/marriott-a-content-marketing-mecca/308365/

New Belgium Brewing. (2016, March 28). Retrieved from twitter.com/newbelgium/status/714583102010470404

New Belgium Brewing. (2017, March 2). New Belgium named Colorado's most ethical manufacturer. Retrieved from https://twitter.com/newbelgium/status/837429860553342976

Newkirk, V.R. (2017, May 22). The supreme court finds north carolina's racial gerrymandering $\begin{array}{llll}\text { unconstitutional. } & \text { The } & \text { Atlantic. } & \text { Retrieved }\end{array}$ https://www.theatlantic.com/politics/archive/2017/05/north-carolina-gerrymandering/527592/ 
Nichols, J. M. (2016, April 13). New 'don't be mean to people' beer is fighting bigotry in north carolina. The Huffington Post. Retrieved from http://www.huffingtonpost.com/entry/north-carolinabreweries-house-bill-2_us_570e7122e4b03d8b7b9f0cd1

Nooyi, I. (2016, April 1). Everyone should be treated with dignity and respect, no matter where they live. My open letter on \#HB2. Twitter. Retrieved from https://twitter.com/indranooyi/status/715977423532130306

Nyssen, M. (2007). Social enterprise: At the Crossroads of Market, Public Policies, and Civil Society. Routledge.

O'Brien, M. (2016, June 7). What makes ben \& jerry's so good at social? ClickZ. Retrieved from https://www.clickz.com/what-makes-ben-jerrys-so-good-at-social/101187/

O’Connor, C. (2014, August 29). Two months on from Hobby Lobby ruling, grocery co-ops dump Eden $\begin{array}{lllll}\text { Foods products from } & \text { shelves. Forbes. Retrieved from }\end{array}$ http://www.forbes.com/sites/clareoconnor/2014/08/29/two-months-on-from-hobby-lobby-rulingco-ops-remove-eden-foods-products-from-shelves/\#4bc0dd5190f6

Omar, A. (2016, December 30). North Carolina judge blocks attempt to strip governor of some powers. Retrieved from http://www.npr.org/sections/thetwo-way/2016/12/30/507596140/north-carolinajudge-blocks-attempt-to-strip-governor-of-some-powers

O'Reilly, D (producer). (2017, May 4). Grab your wallet: When brands go political. Under the Influence with Terry O'Reilly. Pirate Studies: Toronto, Ontario. Retrieved from http://www.cbc.ca/radio/undertheinfluence/grab-your-wallet-when-brands-go-political$\underline{1.4098280}$ 
Papacharissi, Z. (2010). A Private Sphere: Democracy in a Digital Age. Polity.

Park, D. J., \& Berger, B. K. (2004). The presentation of CEOs in the press, 1990-2000: Increasing salience, positive valence, and a focus on competency and personal dimensions of image. Journal of Public Relations Research, 16(1), 93-125.

PayPal. (2016a, March 23). Inclusion is one of our core values... Twitter.com. Retrieved from https://twitter.com/paypal/status/712849862564315136?lang=en

PBS News Hour (2016, April 28). How north carolina's bathroom bill sparked a business backlash. Roben Farzad (producer). YouTube. Retrieved from https://www.youtube.com/watch?v=oOnpo7cXAA\&list=PLXsC-UsRND0PW-gWSlttHBjvL0WWr10Ox\&index=7

Peralta, K. (2016, May 2). For businesses backing hb2, privacy and religious freedom are focal points. $\begin{array}{llll}\text { The } & \text { Charlotte } & \text { Observer. } & \text { Retrieved }\end{array}$ http://www.charlotteobserver.com/news/business/article75129037.html

Peters, S. (2016, May $\left.2^{\text {nd }}\right)$. Nearly 200 major business leaders against hb2 as mccrory \& berger double down on discrimination. HRC.org. Retrieved from http://www.hrc.org/blog/nearly-200-majorbusiness-leaders-against-hb-2-as-mccrory-berger-doubledow?hootPostID=9b0734a6c7fd704716998a353e2da3f2

Pharr, S.J., Putnam, R.D., Dalton, R.J. (2000). A quarter-century of declining confidence. Journal of Democracy 11(2), 5-25

Plantin, J. C. (2015). The politics of mapping platforms: Participatory radiation mapping after the Fukushima Daiichi disaster. Media, Culture \& Society, 37(6), 904-921. 
Powers, L. (2016, April 13). Anti-LGBT laws push corporations to forefront of equality fight. CBC News. Retrieved from http://www.cbc.ca/news/business/north-carolina-lgbt-corporations-1.3530135

Pulizzi, J. (2012). The rise of storytelling as the new marketing. Publishing Research Quarterly 28 (2), p. 116-123.

Purdy, J. (2016, May 10). Transgender rights and the end of the new south. The New Yorker. Retrieved from http://www.newyorker.com/news/news-desk/how-north-carolina-governor-pat-mccrory$\underline{\text { stumbled-on-transgender-rights }}$

Ramaswamy, V., \& Ozcan, K. (2016). Brand value co-creation in a digitalized world: An integrative framework and research implications. International Journal of Research in Marketing, 33(1), 93106.

Reid, N., McLaughlin, R. B., \& Moore, M. S. (2014). From yellow fizz to big biz: American craft beer comes of age. Focus on Geography, 57(3), 114-125.

Research Triangle Region. (n.d.). Business Climate. Retrieved from http://www.researchtriangle.org/assets/business-climate

Rheingold, H. (2007). Smart Mobs: The Next Social Revolution. Basic books.

Roberts, S., Snee, H., Hine, C., Morey, Y., \& Watson, H. (Eds.). (2016). Digital methods for social science: An interdisciplinary guide to research innovation. Springer.

Roy, T. (2016, April 18). Social media frequency 2016: How often you should post. Retrieved from https://www.linkedin.com/pulse/social-media-frequency-2016-how-often-should-you-post-tom$\underline{\text { roy }}$ 
Samu, S. \& Wymer, W. (2014). Cause marketing communications: Consumer inference on attitude towards brand and cause. European Journal of Marketing 48 (7/8), p. 1333-1353.

Sander, T.H. \& Putnam, R.D. (2010). Still bowling alone? Journal of Democracy 21 (1), p. 9-14.

Schnell, S. M., \& Reese, J. F. (2003). Microbreweries as tools of local identity. Journal of Cultural Geography, 21(1), 45-69.

Schulman, D. (2016, April 5). PayPal withdraws plans for charlotte expansion. Paypal Stories. Retrieved from https://www.paypal.com/stories/us/paypal-withdraws-plan-for-charlotte-expansion

Shtern, J., Branche, K., Hill, S., and Chan, D. (2017, June). Sponsored authenticity-the work of social media content creation in the influence economy. Panel presentation at the annual meeting of the Canadian Communication Association, Toronto, Ontario.

Shtern, J., Landry, N., \& Raboy, M. (2012). The least imperfect form of global governance yet? Civil society and multi-stakeholder governance of communication in Frau-Meigs, D., Nicey, J., Palmer, M., Pohle, J., \& Tupper, P. (Eds). From NWICO to WSIS: 30 Years of Communication Geopolitics-Actors and Flows, Structures and Divides, 187-198. Chicago: Intellect.

Smith, L. (2017, May 17). Avant-garde activism: North Carolina's grassroots war against HB2. Huffington Post. Retrieved from http://www.huffingtonpost.com/logan-smith/avant-garde-activismnort_b_9996202.html

Socarides, R. (2016, March 28). North Carolina and the gay-rights backlash. The New Yorker. Retrieved from http://www.newyorker.com/news/news-desk/north-carolina-and-the-gay-rights-backlash 
Sorenson, A. (2016, April 1). Businesses keep piling on for and against house bill 2. Times Warner Cable News. Retrieved from http://www.twcnews.com/nc/charlotte/news/2016/04/1/businesses-keeppiling-on-for-and-against-hb2.html

Stolle, D., Hooghe, M., \& Micheletti, M. (2005). Politics in the supermarket: Political consumerism as a form of political participation. International political science review, 26(3), 245-269.

Steele, L. (2016, April 13). North Carolina brewers protest hb2 with “don't be mean” beer. Men 's Journal. Retrieved from http://www.mensjournal.com/food-drink/articles/north-carolina-brewers-protest$\underline{\text { hb2-law-with-dont-be-mean-beer-w202418 }}$

Sullivan, L. (2017, June 12). Facebook updates lookalike audiences, launches value optimization. MediaPost. Retrieved from https://www.mediapost.com/publications/article/302710/facebookupdates-lookalike-audiences-launches-val.html

Sumofus.org. (n.d.). Stop the bayer-monsanto mega merger. Retrieved from https://actions.sumofus.org/a/stop-the-bayer-monsanto-mega-merger

Surowiecki, J. (2014, August 4). Companies with benefits. The New Yorker. Retrieved from http://www.newyorker.com/magazine/2014/08/04/companies-benefits

Trenz, H. J. (2009). Digital media and the return of the representative public sphere. Javnost-the public, 16(1), 33-46.

Turner, F. (2005). Where the counterculture met the new economy: The WELL and the origins of virtual community. Technology and Culture, 46(3), 485-512.

Turow, J. (2012). The daily you: How the new advertising industry is defining your identity and your worth. Yale University Press. 
Twcnews.com. (n.d.) House Bill 2. Retrieved from http://www.twcnews.com/nc/trianglesandhills/politics/house-bill-2.html

Uttar, J. (2016, April 22). Nascar's brian france says that sport opposes controversial new n.c. law. Motorsport.com. Retrieved from https://www.motorsport.com/nascar-cup/news/nascar-s-brianfrance-says-sport-opposes-controversial-new-n-c-law-689418/

Vallaster, C. and von Wallpach, S. (2013). An online discursive inquiry into the social dynamics of multistakeholder brand meaning co-creation. Journal of Business Research 66(9), p. 1505-1515.

Vanhamme, J., \& Grobben, B. (2009). "Too good to be true!". The effectiveness of CSR history in countering negative publicity. Journal of Business Ethics, 85, 273-283.

Victor, D. (2017, April 5). Pepsi pulls ad accused of trivializing black lives matter. The New York Times. Retrieved from https://www.nytimes.com/2017/04/05/business/kendall-jenner-pepsi-ad.html

Wallace, C. (2016c, May 8). Interview by C. Wallace. Fox News Sunday [Television broadcast]. New York City: Fox News Channel.

WBTV. (2016, April 6). Large and small business react to HB2. Raycom News Network. Retrieved from http://raycomgroup.worldnow.com/story/31661129/large-and-small-businesses-react-to-hb2

Weissner, D. (2016, July 8). Major u.s companies ask judge to block nc transgender bathroom law. Reuters. Retrieved from http://www.reuters.com/article/usa-companies-transgenderidUSL1N19U1X3

Yin, R. (2003). Case Studies Research. Sage Publications: New Delhi. 
Youde, J. (2009). Ethical consumerism or reified neoliberalism? Product (RED) and private funding for public goods. New Political Science 31 (2), 201-220.

Zillman, C. (2015, July 13). Changing genders at work: Inside the fortune 500's quiet transgender revolution. Fortune. Retrieved from http://fortune.com/2015/07/13/transgender-fortune-500/ 